\title{
Female genital cutting in Somaliland: Baseline assessment
}

Katy Newell-Jones

Follow this and additional works at: https://knowledgecommons.popcouncil.org/departments_sbsr-rh

Part of the Demography, Population, and Ecology Commons, Family, Life Course, and Society Commons, International Public Health Commons, Maternal and Child Health Commons, and the Sociology of Culture Commons How does access to this work benefit you? Let us know!

\section{Recommended Citation}

Newell-Jones, Katy. 2017. "Female genital cutting in Somaliland: Baseline assessment." Nairobi: Population Council. 
Female genital cutting in Somaliland:

\section{Baseline assessment}

Somaliland Family Health Association (SOFHA)

Katy Newell-Jones, Orchid Project | January 2017

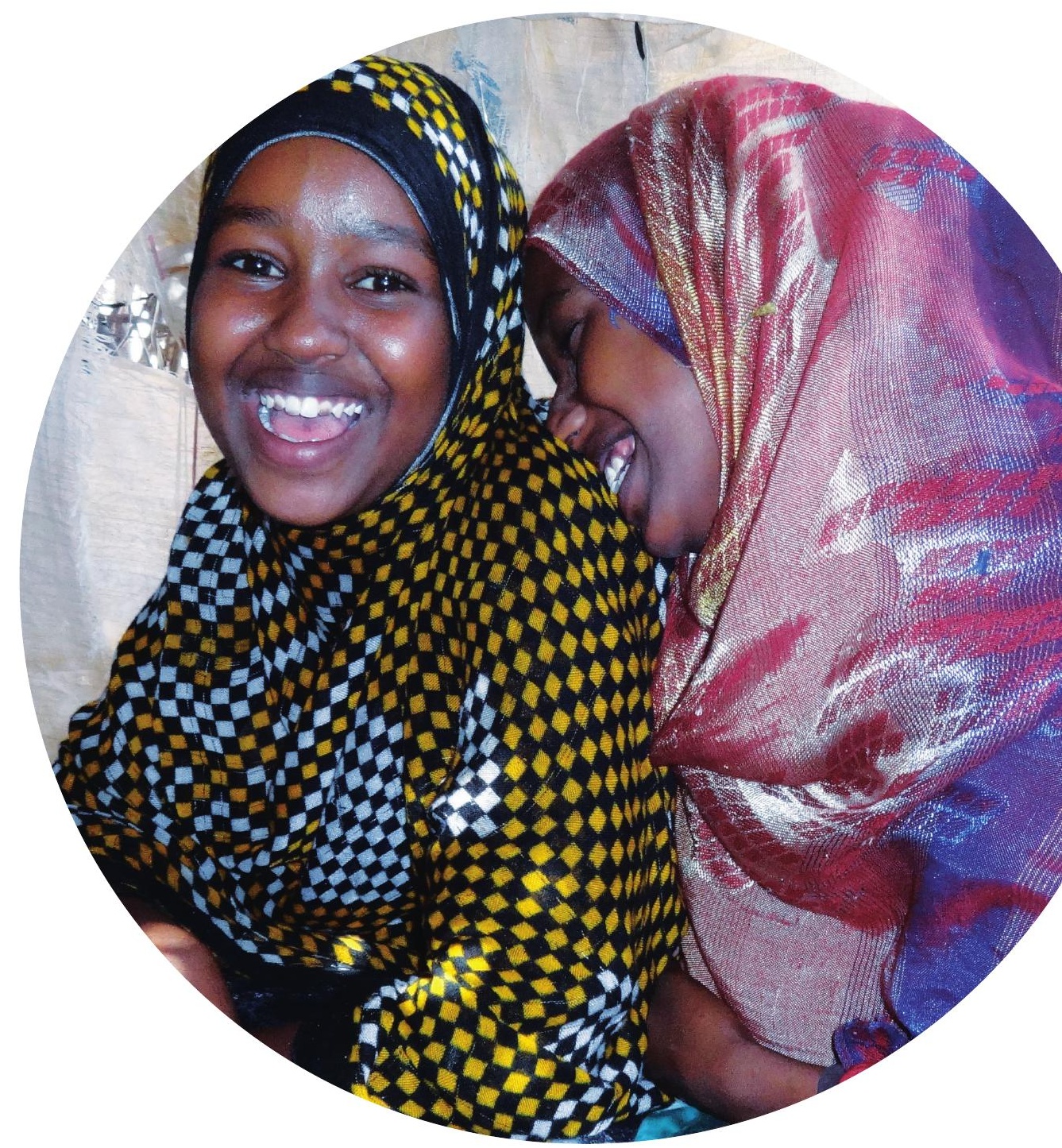

Somaliland Family Health Association

POPULATION
COUNCIL
Ideas. Evidence. Impact.

ORCHID PROJECT

WORKING TOGETHER TO END FEMALE GENITAL CUTTING

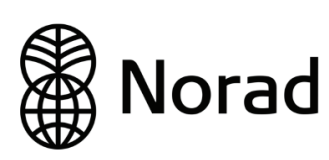


The female genital mutilation/cutting (FGM/C) Research Capacity Building project's main purpose is to provide high-quality research-based evidence to support Norway's 2014-2017 strategy for intensifying international efforts to eliminate FGM/C.

The project is led by Population Council, Nairobi and funded by the Norwegian Agency for Development Cooperation (Norad) providing support and building capacity to generate and use research evidence amongst Norad partners - Somaliland Family Health Association (SOFHA) based in Somaliland, Norwegian Church Aid and Save the Children in Ethiopia and Norwegian Church Aid and Save the Children in South-Central and Puntland Somalia.

Somaliland Family Health Association Health. Community. Partnership.
SOFHA works in the field of reproductive health in Somaliland as well as all of its crosscutting issues. In Somaliland, there is no issue more interwoven into women's health than FGM/C. SOFHA is determined to see the end of FGM/C in one generation and is working with local and international partners to develop and implement evidenced based interventions.

Orchid Project has a vision of a world free from female genital cutting (FGC). Orchid Project was set up in 2011 to pursue this vision and works as a catalyst for change to foster and accelerate the abandonment of FGC. As a UK charity with global reach Orchid Project works through partnering, sharing and advocacy to end FGC worldwide. www.orchidproject.org

Population Council confronts critical health and development issues-from stopping the spread of HIV to improving reproductive health and ensuring that young people lead full and productive lives. Through biomedical, social science, and public health research in 50 countries, we work with our partners to deliver solutions that lead to more effective policies, programs, and technologies that improve lives around the world. Established in 1952 and headquartered in New York, the Council is a nongovernmental, non-profit organisation governed by an international board of trustees. www.popcouncil.org

\section{To cite this report:}

Newell-Jones, K. 2017. 'Female genital cutting in Somaliland: Baseline assessment', January 2017

Please address any inquiries about the FGM/C Research Capacity Building project to: Dr. Jacinta Muteshi, Project Director, jmuteshi@popcouncil.org

\section{Funded by:}

The views and interpretations in this report are those of the author and do not necessarily represent those of the Norwegian Agency for Development Cooperation (Norad).

\section{Designed by:}

thespaceroom.com

(C) 2017 Population Council, Inc. All rights reserved. 


\section{Aknowledgements}

This research was carried out by Somaliland Family Health Association (SOFHA) with technical support from Dr. Katy Newell-Jones, Orchid Project, and in close collaboration with Population Council. The research team wish to thank all eight community researchers who carried out the data collection, the community mobilisers in each community and the various community members who participated in the research, sharing their experiences and opinions so openly.

The report was written by Dr. Katy Newell-Jones, Independent Consultant at Orchid Project. The author of this report is grateful for insightful review and comments by Amal Ahmed, Executive Director, SOFHA, Lucy Walker, Programmes Manager, Orchid Project, Jacinta Muteshi, Project Director, FGM Research Capacity Building Project and Chantalle Okondo, Assistant Programme Officer, Population Council.

The FGM/C project is led by Population Council, Nairobi and funded by the Norwegian Agency for Development Cooperation (Norad) providing support and building capacity to generate and use research evidence amongst Norad partners such as Somaliland Family Health Association based in Hargeisa, Somaliland.

SOFHA works in the field of reproductive health in Somaliland as well as all of its cross cutting issues. In Somaliland there is no issue more interwoven into women's health than FGM. SOFHA is determined to see the end of FGM in one generation and is working with local and international partners to develop and implement evidenced based interventions.

(c) 2017 Population Council, Inc. All rights reserved. 


\section{Contents}

Executive Summary 5

1. Context of female genital cutting in Somaliland 6

1.1 Terminology 6

1.2 Existing knowledge $\quad 6$

1.3 Gaps in existing knowledge $\quad 7$

2. Methodology 8

2.1 Terms of Reference for the baseline research 8

2.2 Overall approach 8

2.3 Research tools 8

2.4 Data collection 9

2.5 Analysis 9

2.6 Sample size $\quad 9$

2.7 Limitations $\quad 11$

3. Research findings $\quad 12$

3.1 Prevalence of female genital cutting amongst women and girls in Somaliland (Goal 1)

3.2 Complications of female genital cutting and access to clinical and support services (Objective 4a)

3.3 Knowledge of the types of cut and their effects on girls and women (Objective 2b) $\quad 18$

3.4 Messages heard on female genital cutting (Objective 2c) 19

3.5 Support for abandonment of female genital cutting (Objectives 2a and 2d) 22

3.6 Attitudes of young people 27

3.7 Attitudes of teachers and the role of schools in abandoning female genital cutting $\quad 29$

4. Key Themes $\quad 35$

4.1 Change is happening and hoped for by over $90 \%$ of community members 35

4.2 Increased medicalisation of cutting 35

4.3 Knowledge and awareness among communities is higher than anticipated 36

4.4 Opportunities to exchange experiences and opinions about female genital
cutting are limited

4.5 People face decision-making dilemmas about female genital cutting 36

4.6 Schools require support to become environments for change 37

4.7 Youth (female and male) are an untapped resource for change 37

4.8 Promoting health seeking behaviour receives limited attention 38

5. Implications for the project $\quad 39$

$\begin{array}{ll}5.1 \text { Selecting and supporting change agents } & 39\end{array}$

5.2 Approaches to 'sessions' $\quad 39$

5.3 Promoting health seeking behaviour $\quad 39$

5.4 Supporting schools $\quad 39$

5.5 Training manuals and handbooks $\quad 39$

6. Recommendations for monitoring, evaluation and learning $\quad 40$

7. Conclusions $\quad 43$

Appendix A: Terms of Reference $\quad 44$

Appendix B: SOFHA project performance monitoring plan 46

Appendix C: Community survey questions $\quad 55$

Appendix D: Interviewees $\quad 57$ 


\section{Executive Summary}

This report summarises research findings into the prevalence and attitudes around female genital cutting (FGC) in 20 communities across 5 regions of Somaliland (Awdal, Maroodi Jeex, Sanaag, Saaxil and Togdheer). A mixed method approach was adopted involving a community survey of 1847 individuals ( $53 \%$ female, $47 \%$ male). There was a specific focus on young people, who accounted for $47 \%$ of the interviewees, and also on the role of schools in promoting abandonment of cutting. The community survey was supported by selected focus group discussions and key informant interviews. This research found that the prevalence of FGC in the 5 regions studied is $98.9 \%$ across all age groups, city, semi-city and village communities.

The type of cut young women and girls report as having undergone is changing from the pharaonic towards the intermediate cut and sunna. Among $15-24$ year olds, $38 \%$ underwent the pharaonic cut, $33 \%$ the intermediate cut, $27 \%$ the sunna and less than $1 \%$ remain uncut. This change is greatest among young women who attend school.

There is evidence of increasing pressure towards the medicalisation of cutting. $11 \%$ of young women (15-24 years) interviewed were cut by a health professional (nurse, midwife, doctor), with $16 \%$ of women reporting that their own daughters were cut by a health professional. The trend is strongest in city and semi-city communities and among those who have attended school.

$90 \%$ of men and women want to see some kind of abandonment, although desire for abandonment exists primarily in relation to the pharaonic. Only $5 \%$ want to see the abandonment of all types of cutting. Men appear to be more open to change than women, with only $2 \%$ of men wanting to retain the current situation in regard to FGC, compared with $17 \%$ of women. Women experience a greater pressure to conform to social norms on FGC and a lack of communication between men and women suggest that women's perception of men's preferences might not always be accurate.

The level of awareness among community members about FGC is higher than anticipated. Virtually all of those interviewed (96\%) knew that there were different types of cut used in their communities. The vast majority of women (94\%) and men (97\%) were able to list complications resulting from cutting with stitches. These findings suggest that decisions about cutting are being made despite people knowing about the types of cut and many of the complications involved. This suggests that lack of knowledge is unlikely to be the primary reason for continued cutting in most instances.

Over half of women said they had experienced severe pain as a result of being cut, irrespective of the type of cut they had undergone. An even higher proportion (75\%) of women said that they have suffered long-term complications as a result of being cut; $77 \%$ of women who had undergone the pharaonic cut and $60 \%$ who had undergone the sunna. Two thirds of these have sought support in dealing with complications arising from being cut, predominantly from a family member. Less than $5 \%$ sought support from a health professional or health provider. There was little evidence of schools supporting health seeking behaviour in relation to $\mathrm{FGC}$ by offering advice on managing complications arising from being cut or of encouraging girls to access health facilities.

Most schools are not actively involved in the movement towards the abandonment of cutting. Few schools have developed policies or whole school approaches to FGC. Advice offered to girls and their parents is limited and often based on the personal efforts
In Somaliland, traditionally most girls and women have undergone the pharaonic cut (WHO type III) with a very small number of girls undergoing the sunna, which involved no stitches (WHO type I). Recently, there has been an increase in the use of the intermediate cut, often referred to as sunna2 (WHO type II). This is seen as causing less damage than the pharaonic cut, yet still partially closes the vaginal orifice with two or three stitches. In this research, the term 'sunna' is used to refer only to WHO type I, which requires no stitches and the term 'intermediate' is used for WHO type II. The community researchers were trained to clarify the precise type of cut to which participants were referring, asking, in Somali, whether or not stitches were involved and if so whether the vaginal orifice was partially or completely closed.

of individual teachers. Twice as many (84\%) teachers felt that schools had a role to play in relation to FGC than had actually spoken about it at school (42\%). More awareness raising as well as capacity building is needed among teachers in order for them to be effective change agents.

Although $72 \%$ of people have heard messages about FGC there is little dialogue taking place among families. In community meetings and workshops, community members are expected to listen to 'facts' presented by 'experts'. In most school sessions parents and girls are expected to be passive listeners, rather than being encouraged to discuss their experiences and opinions about FGC. In focus group discussions, participants reported that these were the first opportunities to exchange opinions and discuss FGC among themselves and many reported changing their opinions on the type of cut they would prefer their daughters to undergo.

Decision-making in relation to FGC involves complex decisionmaking dilemmas. Parents, for example, are balancing conforming to the social expectations to verify their daughters' purity and virginity by cutting, whilst simultaneously not wanting their daughters to suffer from complications as a result of being cut. Midwives and other health professionals are faced with the contradiction between their personal preference, their understanding of their professional role and the pressure they feel under to minimise the harm done to an individual girl. Teachers are faced with balancing their personal opinions on cutting and their understanding of the role of their school.

It appears that decision-making in relation to FGC is less to do with having accurate knowledge, and more to do with making difficult decisions. This has implications for the kinds of activities and interactions which are most likely to successfully bring about changing attitudes and, in turn, abandonment of FGC.

Further research is required to understand the factors influencing decision-making at family and community levels in Somaliland. 


\section{Context of female genital cutting in Somaliland}

\subsection{Terminology}

The terminology used in relation to female genital cutting (FGC) in Somaliland is complex. Table 1.1A indicates the three broad categories of cut currently being used, how they relate to the WHO classification and the terms used in this research.

Table 1.1A: Classification of types of female genital cutting as used in SOFHA research (linked to WHO classification)

\begin{tabular}{|l|l|}
\hline $\begin{array}{l}\text { Sunna } \\
\text { (no stitches) } \\
\text { WHO type I }\end{array}$ & $\begin{array}{l}\text { Partial or complete removal of the clitoris (clitoridectomy), requiring no stitching. } \\
\text { Often described as removing the tip of the clitoris in Somaliland. }\end{array}$ \\
\hline $\begin{array}{l}\text { Intermediate cut } \\
\text { WHO type II }\end{array}$ & $\begin{array}{l}\text { Partial or total removal of the clitoris and the labia minora, with or without excision of the labia majora } \\
\text { (excision), requiring } \mathbf{2} \text { or } \mathbf{3} \text { stitches to partially close the vaginal orifice. } \\
\text { Often referred to as sunna or sunna2 in Somaliland. }\end{array}$ \\
\hline $\begin{array}{l}\text { Pharaonic cut } \\
\text { WHO type III }\end{array}$ & $\begin{array}{l}\text { Narrowing of the vaginal orifice with creation of a covering seal by cutting and re-stitching the labia minora } \\
\text { and/or the labia majora, with or without excision of the clitoris (infibulation), requiring 4-7 stitches and } \\
\text { resulting in only a very small vaginal orifice. }\end{array}$ \\
\hline
\end{tabular}

With Somaliland being predominantly Sunni Muslim, from the Shafi'i school of thought, FGC is considered by most not to be mandated by Islam in the Qur'an, but subject to guidance, called a 'Hadith' (or 'Sunna') under Sharia law.

Traditionally most girls and women in Somaliland have undergone the pharaonic cut, which equates to WHO type III, with a minority undergoing the sunna, which equates to WHO type I. In recent years, the intermediate cut (WHO type II) has risen in popularity in Somaliland, as it is seen as causing less damage than the pharaonic, yet still partially closing the vaginal orifice with two or three stitches. This intermediate cut is being called 'sunna' or 'sunna2' in the community, which can lead to confusion. Senior clerics and the Ministry of Religious Affairs (MoRA) are opposed to the pharaonic cut and consider only the sunna, with no stitches, to be acceptable under Sharia Law.

In this report, the term 'sunna' is used to refer only to WHO type I, which requires no stitches and the term intermediate is used for WHO type II. The community researchers were trained to clarify the precise type of cut to which participants were referring, asking, in Somali, whether stitches were involved and if so whether vaginal orifice was partially or completely closed.

\subsection{Existing knowledge}

Data from MICS (2006 \& 2011²), Crawford and Ali (2015), Edna Adan University Hospital (EAUH) $\left(2009^{3} \&\right.$ in prep.), NAFIS Network $(2015)^{4}$ and Newell-Jones $(2016)^{5}$ all indicate that Somaliland has an overall prevalence rate of around $99 \%$ of girls and women undergoing FGC.

1. www.childinfo.org/files/MICS3_Somalia_FinalReport_2006_eng.pdf

2. www.unicef.org/somalia/SOM_resources_somalilandmics4_finalreport.pdf

3. http://ednahospitalfoundation.org/wp-content/uploads/2014/10/female-genitalmutilation.pdf

4. NAFIS Network (2015) Assessment of prevalence, perception and attitude of female genital mutilation

5. Newell-Jones K (2016) Empowering communities to collectively abandon FGM/C in Somaliland AAIS/ORCHID https://orchidproject.org/resource/empoweringcommunities-to-collectively-abandon-fgmc-in-somaliland/
MICS (2011) found that $99.1 \%$ of women responding had been cut, with $85 \%$ of them having been sewn closed, therefore experiencing the most extreme form of FGC, infibulation or pharaonic (WHO type III). EAUH found in its survey from 2002 -2006 that $97 \%$ of women had been cut, and in the second survey from $2006-2013$ that $98.4 \%$ of women participating in antenatal examinations had undergone FGC, $82.2 \%$ of whom had experienced the pharaonic cut. The results of the ActionAid research in Maroodi Jeex and Todgheer (Newell-Jones 2016) showed that:

'The overall prevalence rate among community women remains high at $99.4 \%$, with $80 \%$ having undergone the pharaonic cut. There is evidence of a change, particularly in urban communities, away from the pharaonic cut to the intermediate and sunna cuts. Only 34\% of girls aged 12-14 years have undergone the pharaonic cut compared to $96 \%$ of women aged over 25 years. Just $5 \%$ of girls and women are currently cut by health specialists. However, there is widespread evidence of increased medicalisation of cutting, with younger women more likely to have been cut by midwives, nurses or doctors. Many religious leaders and some community leaders are calling for midwives and nurses to be trained to perform the cut safely and hygienically.'

MICS, EAUH and Newell-Jones all show that women are not universally in favour of the continuation of FGC, yet almost all of them are cut themselves and many of them intend to cut their own daughters. Crawford and Ali (2015) interviewed some men about their attitudes, however, the numbers involved are relatively small and they identify the need for more research data from men and boys about their knowledge, attitudes and beliefs around FGC in Somaliland. Further data has been provided by Newell-Jones (2016) indicating that men are often not well-informed about the different types of cut being used in Somaliland and therefore are open to misinformation about what is happening to their daughters or sisters. This study also highlighted the decision-making dilemmas which many parents face, often not wanting to harm their daughters but also wanting to conform in order to be able to demonstrate their daughter's virginity. Given that FGC is identified as a pre-requisite for 
marriage, the attitudes and expectations of men and boys are an important factor in understanding the drivers in relation to the continuation of the practice.

There is clear evidence from the research in Maroodi Jeex and Togdheer of a desire for change in relation to FGC among all stakeholder groups, including religious leaders, the MoRA and senior clerics (Newell-Jones 2016). Only 18\% of community members would like to maintain the existing situation in their community, leaving $82 \%$ in favour of change of some sort. The preferred option is a move towards the abandonment of the pharaonic cut. However, less than $10 \%$ of community members supported the introduction of a law based on Zero Tolerance and only around $5 \%$ aspired to an abandonment of all forms of cutting in their community.

\subsection{Gaps in existing knowledge}

This baseline research aims to shed light on the following specific areas, as well as providing baseline data against which progress can be monitored in the current SOFHA project (see Terms of Reference 2.1 for the specific goals and objectives).

Prevalence rates and types of cut of female genital cutting among young girls

There is limited data on the prevalence of FGC among young girls, although the research in Maroodi Jeex and Togdheer (NewellJones 2016) indicated that there was only a very small decrease in the overall prevalence but a shift away from the pharaonic towards the intermediate and sunna cuts. Further research into the factors causing such shifts would be valuable, including perhaps the messages given by different schools and the level of education among parents.
The role of schools in the abandonment of female genital cutting

Previous research (Newell-Jones 2016) indicated that schools do not currently play a strong role in actions to promote the abandonment of FGC in Somaliland, however, they are influential places attracting respect from across the community. Those who have attended school are less likely to have undergone the most severe forms of FGC, suggesting that there is a link between access to education and decision-making in relation to FGC. In countries where the prevalence of FGC has decreased, schools have played a significant role in the dissemination of information and in providing forums for parents and children to talk. SOFHA already had strong connections across the Ministry of Education, nationally and regionally, and also among schools, hence the inclusion of schools and teachers in this project and the baseline research.

Access to health support services in relation to female genital cutting

The government is working with health workers to curb the move towards medicalisation and to support their role as providers of guidance for the abandonment of cutting and advice and support for girls and women who have been cut. However, there is little evidence of the kind of support which young girls seek or the skills among health workers for this role.

The potential role of young men towards the abandonment of female genital cutting

There is general agreement that young men are key stakeholders in the abandonment of FGC in Somaliland, especially given that marriage is seen as the source of social-economic status and stability for many women in Somaliland. However, relatively little is known about the attitudes of young men and how they see their role in the movement towards abandoning all forms of cutting.

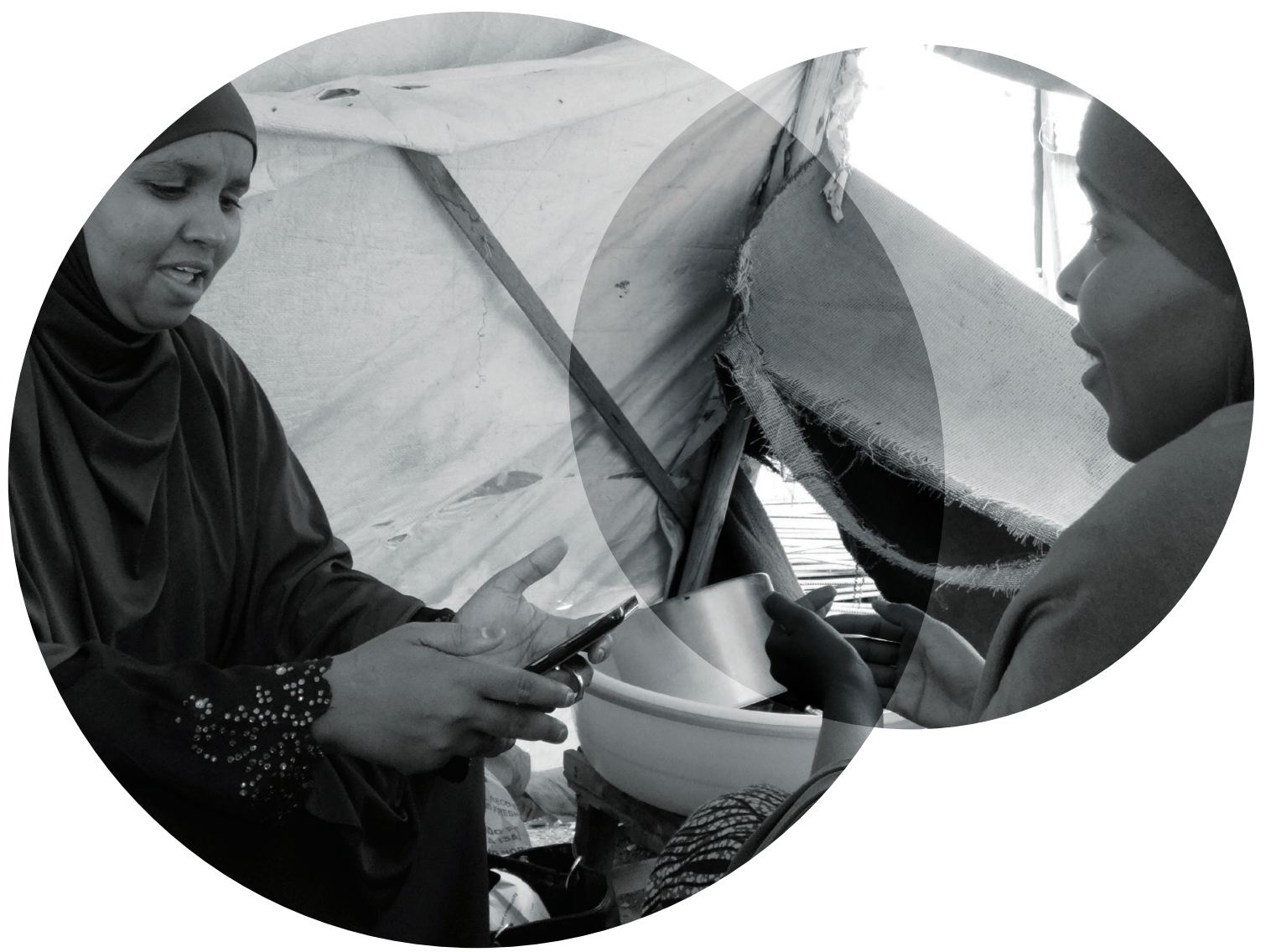




\section{Methodology}

\subsection{Terms of Reference for the baseline research}

This baseline research was carried out across five regions in Somaliland (Awdal, Maroodi Jeex, Sanaag, Saaxil and Togdheer) with the following four objectives:

- To identify the prevalence of FGC among women and school aged girls

- To understand the knowledge, attitude and practice regarding FGC among parents, adolescents and teachers

- To investigate young men's future preferences and their role in interventions to end FGC

- To gather relevant baseline data for key project indicators to enable changes in beneficiaries' lives to be measured over the course of the project.

Below are those key project indicators specifically identified for the baseline research.

\begin{tabular}{|l|l|}
\hline Goal 1 & $\begin{array}{l}\text { Prevalence of FGC amongst women } \\
\text { and girls in Somaliland }\end{array}$ \\
\hline Objective 2a * & $\begin{array}{l}\text { Percentage of population supporting } \\
\text { abandonment of FGC }\end{array}$ \\
\hline Objective 2b & $\begin{array}{l}\text { Percentage of people who know the } \\
\text { effects of FGC }\end{array}$ \\
\hline Objective 2c & $\begin{array}{l}\text { Percentage of people who report to } \\
\text { have heard anti-FGC messages }\end{array}$ \\
\hline Objective 2d $*$ & $\begin{array}{l}\text { Percentage of population NOT } \\
\text { supporting alternative FGC }\end{array}$ \\
\hline Objective 4a & $\begin{array}{l}\text { Percentage of women and girls affected } \\
\text { by FGC who have received FGC related } \\
\text { clinical and support services }\end{array}$ \\
\hline
\end{tabular}

* Objectives $2 \mathrm{a}$ and $2 \mathrm{~d}$ are linked and have been combined for the purpose of the baseline study.

See appendix A for the full Terms of Reference and appendix B for the full list of project indicators from the project management plan (PMP).

\subsection{Overall approach}

SOFHA adopts a social norms approach to FGC, recognising that the decisions individual households make about whether or not to cut their daughters and the type of cut to use are influenced significantly by the expectations, real or imagined, of those they interact with on a regular basis. The selection of a community survey as the primary data collection was in line with a social norms approach as it gathered data on the opinions and attitudes of a wide range of community members.

The baseline research used a mixed method approach involving a community survey supported by a series of focus group discussions and key informant interviews. Self-reporting was used as the means of gathering data on the prevalence and types of cut women and girls had undergone.

An initial community mapping activity across all regions of Somaliland informed the selection of the regions and communities in which the data collection took place.

The primary data collection was a community survey which involved individual interviews using a survey questionnaire. This was supported by a series of focus group discussions and key informant interviews.

\subsection{Research tools}

The questionnaire for the community survey was developed through collaboration between the consultant and the SOFHA team. It used Open Data Kit software and smartphones for mobile data collection. The topics covered by the questions are listed below. See appendix $\mathrm{C}$ for the full list of questions.

- Introduction - name, gender, age, community, education, role (teacher, health professional, home-based, farmer etc.), married, parent, daughters in primary grades 1-3

- Knowledge of types of cut - sunna, sunna2/intermediate and pharaonic

- Knowledge of complications of cutting with and without stitches

- Intentions for future daughters, preferences for daughtersin-law

- Messages heard - where from, what types of messages

- Anti-FGC activities - current involvement, what type, future involvement, what type, barriers to involvement

- Aspirations for abandonment - the pharaonic, the intermediate, all types of cutting

\section{- Personal questions for women}

- Questions about their own experience - whether they were cut, which type, age, who cut, complications, health seeking behaviour, whether they were re-cut in preparation for marriage

- Questions about their daughters - whether they were cut, which type, who cut, complications

- Unmarried men's preferences for future wife, does the cut status of their future wife matter

- Teachers - role of school, whether they talk about cutting in school, who with, messages given, requests for advice, actions before long holidays. 
Obtaining ongoing consent was built into the questionnaires, for example before personal questions were asked of women about their own experience of being cut they were asked if they were willing to continue with the questionnaire. The questions were available in both Somali and English.

Most questions had a series of response options (see appendix C). The community researchers did not read the list out but allowed the interviewees to talk in response to the question and then selected the appropriate response(s) from the options, or ticked other and inserted text for responses not listed.

The questionnaire was piloted firstly among the community researchers and the SOFHA team during the workshops on ethical research and secondly with community men and women. The questionnaire was refined as a result of feedback from piloting activities.

The focus group discussions and key informant interviews followed a semi-structured approach, covering the same broad themes as the questionnaires, although allowing for discussion among participants and follow up questions.

\subsection{Data collection}

Data collection was carried out by a team of eight trained community researchers, four female and four male. The community researchers were supported by the senior SOFHA team who coordinated the data collection process, accompanying the community researchers to the communities, monitoring the process and ensuring the data was uploaded to the server daily.

The consultant facilitated a series of workshops on ethical research prior to the data collection for the SOFHA team and the community researchers. These workshops covered the key principles of ethical research, differences between research and project implementation, informed consent, incentives, child protection, confidentiality, managing distress and minimising researcher bias as well as the practicalities of sampling, data collection and security.

All interviews were carried out in Somali by a person of the same gender as the interviewee. The team of community researchers worked in two teams of two male and two female community researchers.

In each target community, the research team aimed to interview approximately 100 people, with a balance of community women and men from different backgrounds and specifically including young men and women from school, university and the community. The sampling process was biased in favour of young women and men as these are an important target group which SOFHA considers to be particularly important in relation to female genital cutting.

Female community researchers visited schools and health clinics, selected randomly from community lists, and also undertook a household survey, again selecting households at random. Male community researchers visited schools, tea rooms and mosques where men were likely to gather. Specific locations were selected using random selection techniques (dice and a pencil compass). Individual interviewees at each location were selected again using random selection techniques.

\subsection{Analysis}

The data analysis was a collaborative process involving the consultant and the SOFHA team through a rigorous process of review and refinement. The community survey data forms the basis of the findings. Key themes were identified from the focus group discussions and key informant interviews which were verified by the SOFHA team members responsible for the translation during these activities.

\subsection{Sample size}

Data collection took place in 20 specific communities in five regions: Awdal, Maroodi Jeex, Saaxil, Sanaag, Togdheer. Of the 20 communities 13 were urban (10 city, 3 semi-city (large towns) and 7 were village communities (small rural communities)). The SOFHA team felt that the division into the 3 categories of city, semi-city and village reflected the different types of communities. This decision was supported by other civil society organisations (CSOs) and representatives from the Ministries of Education, Health and Labour and Social Affairs.

A total of 1847 individuals were interviewed as part of the community survey with an average of 92 people per community. (see table overleaf). In some communities, people were engaged in community meetings which prevented the team reaching the target number of interviews. In other drought-affected communities it was not possible to reach the target number of interviews.

Overall, of the 1847 interviewees, 971 (53\%) were female and $876(47 \%)$ were male. 859 (47\%) were $15-24$ years of age and $988(53 \%)$ were aged over 25 years. A total of 209 teachers were interviewed.

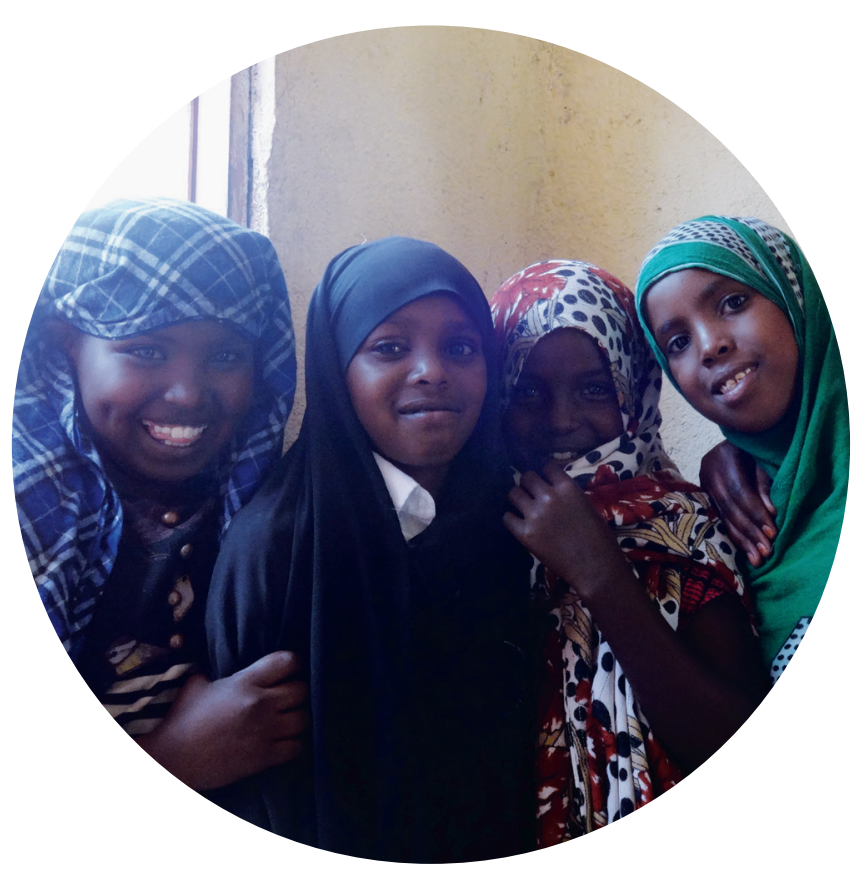




\begin{tabular}{|c|c|c|c|c|c|}
\hline Region & Community & $\begin{array}{l}\text { City/semi-city/ } \\
\text { village }\end{array}$ & $\begin{array}{l}\text { No. female } \\
\text { interviewees }\end{array}$ & $\begin{array}{l}\text { No. of male } \\
\text { interviewees }\end{array}$ & $\begin{array}{l}\text { Total } \\
\text { interviewees }\end{array}$ \\
\hline \multirow[t]{8}{*}{ Sanaag } & Daallo (Cerigabo) & City & 23 & 42 & 65 \\
\hline & Yufle & Village & 60 & 57 & 117 \\
\hline & Gudmo Biyo Cas & Village & 59 & 61 & 120 \\
\hline & October (Sanaag) (Cerigabo) & City & 8 & 19 & 27 \\
\hline & Xaafadsoomaal (Cerigabo) & City & 40 & 31 & 71 \\
\hline & Shacabka (Cerigabo) & City & 55 & 40 & 95 \\
\hline & Other Sanaag * & & 10 & 5 & 15 \\
\hline & Total & & 255 & 255 & 510 \\
\hline \multirow[t]{6}{*}{ Awdal } & Sheeddheer (Borama) & City & 32 & 29 & 61 \\
\hline & Sheekh Ali Jawhar (Borama) & City & 23 & 31 & 54 \\
\hline & Dilla & Semi City & 52 & 45 & 97 \\
\hline & Qulujeed & Village & 54 & 48 & 102 \\
\hline & Gorayo Cawl & Village & 33 & 35 & 68 \\
\hline & Total & & 194 & 188 & 382 \\
\hline \multirow[t]{6}{*}{ Saaxil } & Moskow (Berbera) & City & 54 & 45 & 99 \\
\hline & Barwaaqo (Berbera) & City & 62 & 42 & 104 \\
\hline & Sheekh & Semi City & 53 & 56 & 109 \\
\hline & Abdaal & Village & 48 & 38 & 86 \\
\hline & Xamaas & Village & 50 & 29 & 79 \\
\hline & Total & & 267 & 210 & 477 \\
\hline \multirow[t]{3}{*}{ Togdheer } & Yaroowe & Village & 49 & 47 & 96 \\
\hline & October (Burao) & City & 67 & 49 & 116 \\
\hline & Total & & 116 & 96 & 212 \\
\hline \multirow[t]{4}{*}{ Maroodi Jeex } & Baligubadle & Semi City & 55 & 47 & 102 \\
\hline & Ahmed Dhagax (Hargeisa) & City & 84 & 80 & 164 \\
\hline & Total & & 139 & 127 & 266 \\
\hline & Grand total & & 971 & 876 & 1847 \\
\hline
\end{tabular}

* People interviewed in Sanaag city communities but living in other city communities 
An additional 106 community members took part in 11 focus group discussions with young women, young men, secondary school girls (aged 15 or over), community women and teachers.

Key informant interviews took place with seven people: a Regional Education Officer, a Primary and Secondary School Principal, a gender focus person at a primary school, a traditional cutter and two midwives in community health facilities.

\subsection{Limitations}

\section{Prioritising of target groups}

SOFHA had the difficult task of selecting the specific target groups in order to gain baseline data and also to inform the national debate around FGC. The decision was taken to focus on young people and the role of schools. SOFHA had already developed close links to schools and was aware that schools are not widely perceived as active agents of change in relation to FGC. Additionally, the Ministry of Education is committed to the abandonment of FGC and sees schools as central to achieving change. The research has strong data on these target groups, however, less new information is available on other stakeholders, including religious leaders and health workers, which have been explored in depth by other recent research including the ActionAid research (Newell-Jones 2016).

Reliability of self-reporting data

Many women report that their experience of being cut is etched in their memory with considerable clarity, far more so than other events in their childhood. However, self-reporting on FGC brings with it dangers and limitations as highlighted in the technical briefing 'Considerations on the use and interpretation of survey data on FGM/C (2016)' ${ }^{6}$. Care was taken to reduce reporting inaccuracies by

a. briefing the community researchers by an experienced doctor and community development officer on the types of cut, the names they are called locally,

b. ensuring all interviewing took place in Somali and did not use terms like FGM or circumcision but used local terminology,

c. designing the questions to be as specific as possible on the type of cut and not using euphemisms, like 'purified',

d. basing the differentiation of types on the use of stitches as this is more likely to be known and remembered than whether flesh was or was not removed.

These measures reduced the inaccuracies in understanding between the participant and the researcher. However, as suggested by Shell-Duncan (2016) there are likely to be some errors through lack of memory and the passing of time. Askew (2005:472-473) ${ }^{7}$ concluded that 'if female genital cutting is widespread, socially acceptable and there is no well-publicised intervention causing people to question its acceptability and legality....then self-reporting is likely to be valid'.

\section{Timescale of the data collection process}

The data collection process was relatively short (15 days) due to the need for the SOFHA core team to balance coordinating the research process and also manage their programme commitments. This resulted in only a small number of focus group discussions and key informant interviews being included. The timescale also prevented the research team from returning to communities where fewer people were interviewed to collect additional data. However, the advantages of the capacity building of the SOFHA team by coordinating the research process outweighed the alternative option of employing external people who would be able to dedicate a longer period of time to the process.

\section{Selection of communities affected by local conditions}

There were changes in four of the communities in which the survey took place as a result of local issues. Outbreaks of local violence in communities in Sanaag resulted in the research team having to change communities during the data collection process. In addition to this, one of the rural communities in Saaxil had a major community meeting taking place which meant that there were very few people to interview so the team moved to the nearest village about $5 \mathrm{~km}$ away. 


\section{Research findings}

\subsection{Prevalence of female genital cutting amongst women and girls in Somaliland (Goal 1)}

A total of 881 women, across the 22 target communities in the 5 regions of Awdal, Maroodi Jeex, Saanag, Saaxil and Togdheer, agreed to answer personal questions about whether and how they were cut. Of these, 871 women reported that they had been cut, 7 reported being uncut and 3 were unsure, giving an overall prevalence rate of female genital cutting of $98.9 \%$. The prevalence rate is the same for young women 15-24 years as it is for older women (chart 1).

Chart 1: Overall prevalence of female genital cutting

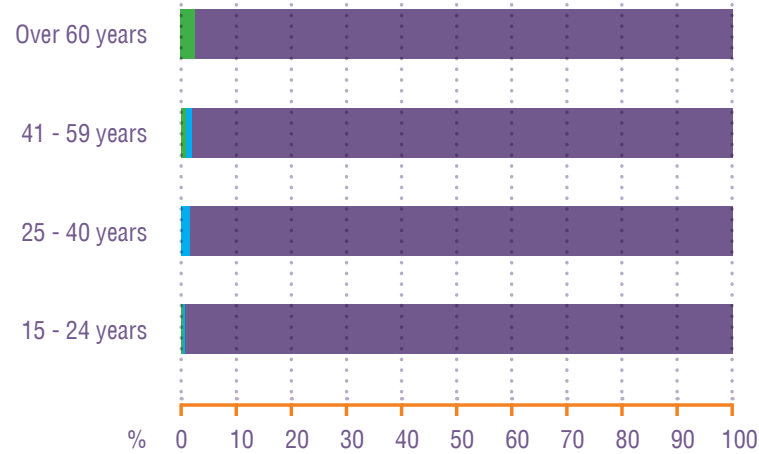

Key

Don't know Uncut Cut

There is strong evidence of a change in the type of cut which younger women are undergoing (chart 2). Almost $90 \%$ of women aged over 25 years underwent the pharaonic cut. This percentage has dropped dramatically in recent years to $38 \%$, with $33 \%$ undergoing the intermediate cut and $27 \%$ undergoing the sunna only.

Chart 2: Type of cut of women by age

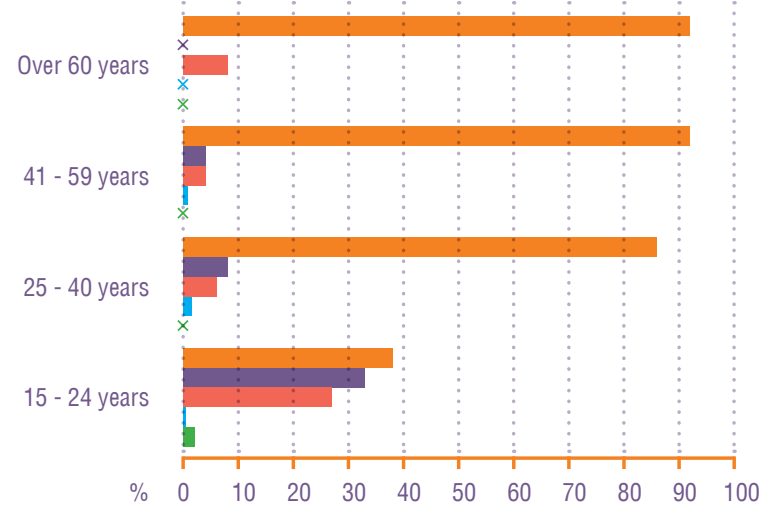

Key

Pharaonic Intermediate Sunna Uncut Don't know/decline
The change in type of cut, from pharaonic to intermediate and sunna, among younger women is reflected in the percentage who have been cut and sewn almost completely closed and are re-opened before being married. Almost all (97\%) of women over 40 were cut open for marriage, as opposed to $71 \%$ of girls and women aged 15-24 (chart 3).

Chart 3: Percentage of married women cut open on their wedding night (by age)

Over 60 years

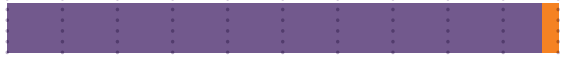

$41-59$ years

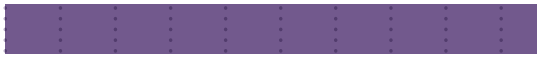

$25-40$ years

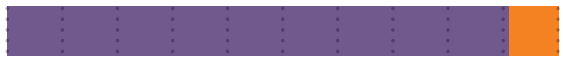

$15-24$ years

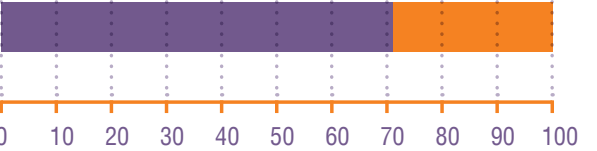

Key

Cut open on wedding night Not cut on wedding night

The reasons given in focus group discussions for the change were mainly concerning the health of girls and women. The term hygiene used below refers to the whole range of complications experienced by girls and women after undergoing the pharaonic cut.

"We used to do the pharaonic cut on all girls but now this has reduced and most young women are having a less severe cut. We changed because we realised all of the problems of hygiene associated with being cut...Every month we used to get infections, and swelling and many other things that women must live with for the rest of their lives after they are cut."

Community woman, Abdaal, village community, Saaxil

The influence of education on female genital cutting

It is widely thought that there is a strong correlation between whether a girl attends school and the severity of the type of cut which she has undergone. This is supported by evidence from this research. Of the young women (aged 15-24 years) interviewed, those who have not attended school at all were more likely to have undergone the pharaonic cut and less likely to have undergone only the sunna (chart 4) than those who have attended school where the pattern of cutting is more equal between the pharaonic cut, intermediate cut and sunna. 
Chart 4: Relationship between education and type of cut undergone among young women aged $15-24$ years

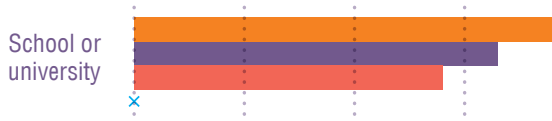

No school

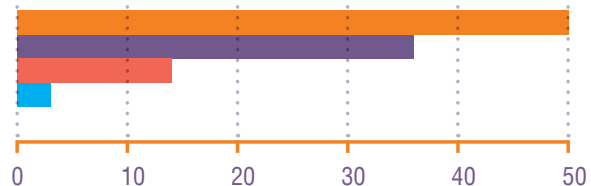

Key

$\% \quad 0$

Pharaonic

Intermediate

The age at which women were cut

There has been a gradual reduction of the age at which girls are cut, with progressively fewer girls being cut aged over 12 years and more being cut aged under 8 years (chart 5 ). $79 \%$ of young women (aged 15-24) interviewed were cut before they were 11 years old. Few, if any, girls remain uncut until such time as they could play a significant role in the decision-making process.

Chart 5: Age at which girls are cut
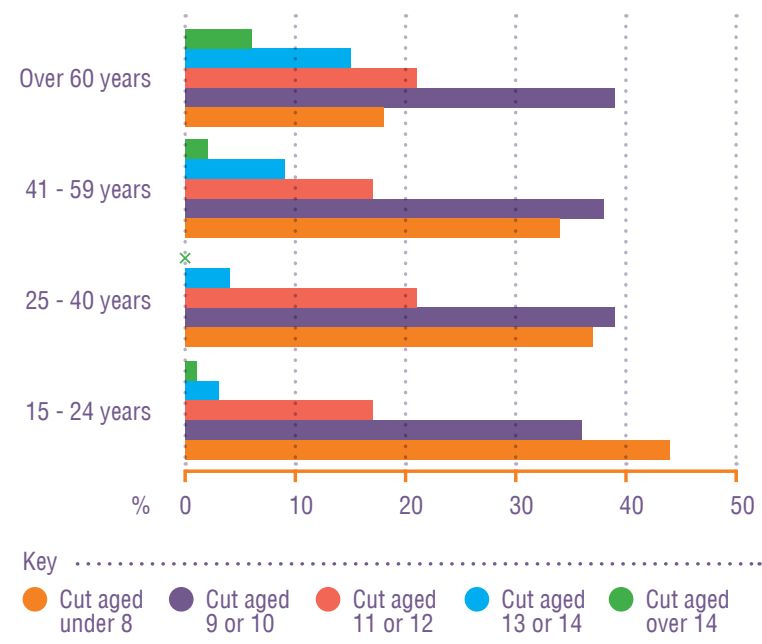

The people who are performing the cutting

The overwhelming majority (92\%) of women were cut by traditional cutters (89\%) or Traditional Birth Attendants (TBAs) (3\%), who usually have strong links with health facilities and whose primary role is supporting women in child birth.

There are signs that this is changing with an increase in the percentage of cutting being performed by qualified health professionals (nurses, midwives and doctors) among younger women (chart 6). Among young women aged 15-24 years, cutting by health professionals comprised $11 \%$ of the cutting. There is also evidence of an increase in the intentions of young women to use health professionals for their own daughters (see section 3.6 chart 42).

Chart 6: Percentage of girls and women cut by health professionals (by age)

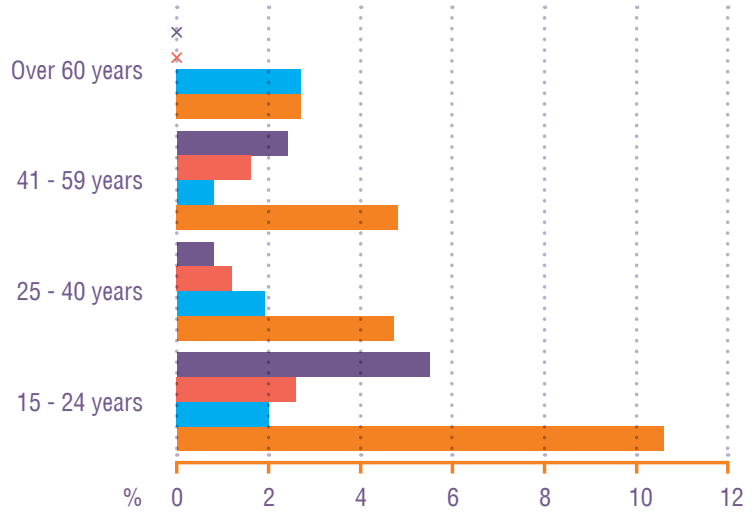

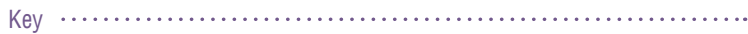

Nurse Midwife Doctor Total health professionals

For the $11 \%$ of families who chose to use a trained health professional (nurse, midwife or doctor) to cut their daughters, $6 \%$ used a nurse, $3 \%$ a midwife and $2 \%$ said they used a doctor. Community members might not be sure of the distinction between a doctor, midwife and nurse, however, the community researchers were careful to ensure that all those recorded as using health professionals were referring to a trained health worker and not using the term nurse or doctor to refer to a traditional cutter or TBA.

There are clear links between attendance at school and university and the type of person used to perform the cutting (chart 7). Families where the girls did not go to school tended to use TBAs, whereas those families where girls attended school and university were more likely to select a trained health professional.

Chart 7: Selection of health professionals as cutters linked to education

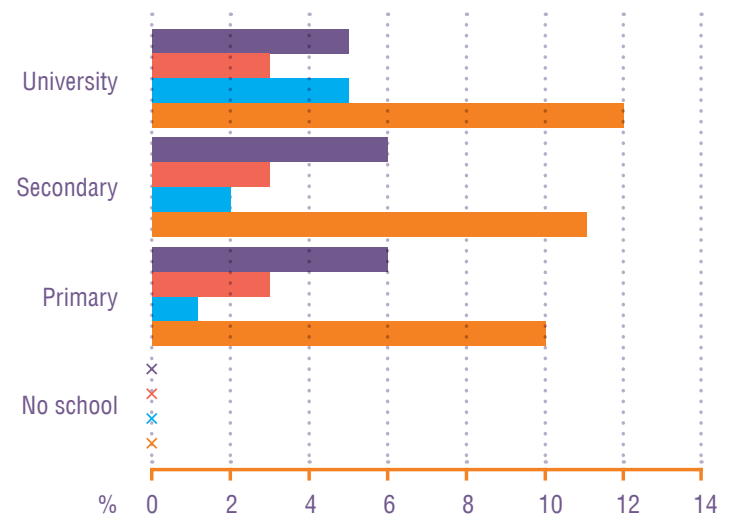

Key

Nurse Midwife Doctor Total health professionals

There are significant differences in the medicalisation of cutting between city, semi-city and village communities (chart 8). In rural villages, where health facilities are limited, only $5 \%$ of cutting is performed by health professionals, as opposed to $11 \%$ in city communities where there are more hospitals and Midwife, Maternal and Child Health centres (MCHs). 
Chart 8: Percentage of girls and women cut by health workers in city, semi-city and village communties

City

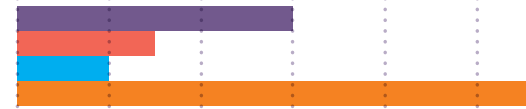

Semi-City

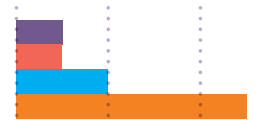

Village

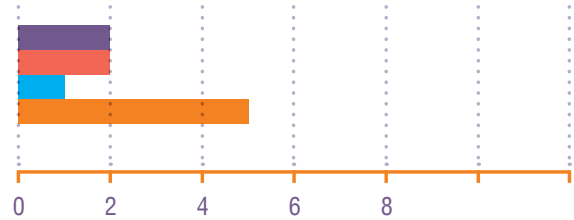

Key

Nurse Midwife Doctor Total health professionals

Further evidence of changing practice comes from the reports from women who have cut their daughters. Overall, $8 \%$ of women interviewed reported that they were cut by a health worker, whereas $16 \%$ reported that they had used a health worker to cut their daughter(s). Once again there is a marked difference between village, semi-city and city communities. Health professionals (nurses, midwives and doctors) perform only $7 \%$ of cutting in village communities, as opposed to $18 \%$ and $24 \%$ of cutting in semi-city and city communities (chart 9).

Chart 9: Percentage of WOMEN'S DAUGHTERS cut by health workers in city, semi-city and village communities

City

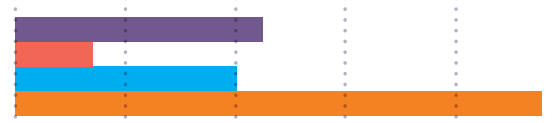

Semi-City

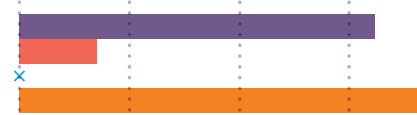

Village

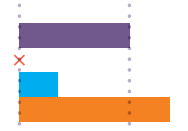

$\% \quad 0$

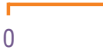

Key

Nurse

Midwife

Doctor

Total health professionals

In the focus group discussions, people talked openly and proudly of using health professionals to perform the cutting.

"the move was initially from the pharaonic to

the intermediate with 2 or 3 stitches but now women take their daughters to the hospital where they have the sunna with no stitches."
"For myself, my daughter would go to the $\mathrm{MCH}$ for a hygienic and safe cut. It is free and safe at the $\mathrm{MCH} . "$

Principal, Sheikh Secondary School

Decision-making dilemmas of health professionals

Health professionals, nurses, midwives and doctors sometimes seem to have contradictory attitudes towards FGC in their personal and professional lives. It is not unusual to meet someone who supports the abandonment of all types of cutting, yet in their professional role they perform the cut on young girls. When questioned, they usually explain this contradiction as a professional dilemma as demonstrated by the example below of an experienced and committed midwife in a rural village maternal health centre. Her name has been changed to protect her identity and that of the $\mathrm{MCH}$.

Midwife, Maternal and Child Health centre (MCH), village community

Zeinab has been a trained midwife for over 10 years. She has been involved in campaigning for Zero Tolerance with a local NGO and would prefer for all types of cutting to stop, including the sunna with no stitches.

Usually in this community, mothers invite a traditional cutter or TBA from Hargeisa or Berbera to perform the cutting on a group of girls. Many of the girls suffer infections, severe pain, difficulties with menstruation and other severe complications. As a midwife, she sees young girls and women seriously damaged by being cut. Zeinab says, "I have to re-open girls for marriage, then cut them again for childbirth. I feel very bad about this painful process".

Some mothers ask her or one of the other two midwives to cut their daughter hygienically with antiseptic. "I always try to persuade the mothers not to cut their daughters by telling them about the complications. Usually they are not persuaded and so I do the sunna, taking off the tip of the clitoris which usually needs 1 or more stitches to stop the bleeding", she says.

Zeinab would prefer to leave the girls untouched but fears that if she refuses they will be harmed much more by going to the TBA. "I always try to persuade them, but if they won't change their minds I do it to stop them being cut somewhere else".

She says there is no payment for cutting girls at the government facility. There are also no records of the procedure being carried out. Every other procedure would be recorded but there is no form for doing female genital cutting, so it goes unrecorded.

She recognises the contradiction between cutting girls and campaigning for Zero Tolerance. "One is what I have to do as a midwife, the other is what I hope for in my community in the future". 
The midwife above clearly blamed the mothers for insisting that she perform the sunna2, a cut with stiches. In the focus group discussions, there were also examples of mothers blaming health professionals for using stitches when they had asked for the sunna with no stitches,

\section{"For myself, my daughter would go to the} Midwife, Maternal and Child Health centre $(\mathrm{MCH})$ for a hygienic and safe cut. It is free and safe at the $\mathrm{MCH} . "$

Community woman, Abdaal, Saaxil

\section{Conclusion}

The overall prevalence rate of $\mathrm{FGC}$ is $98.9 \%$ among the 881 women interviewed. This rate is consistent across the age ranges of the women, whether they live in city, semi-city of village communities or whether or not they attended school.

There is strong evidence of a change in the type of cut which younger women are undergoing and the type of people performing the cut. Almost $90 \%$ of women aged over 25 years underwent the pharaonic cut, as opposed to just $38 \%$ of young women aged $15-24$ years. $27 \%$ of young women underwent the sunna, which is reflected in $29 \%$ of married young women not being re-cut open on their wedding night, as opposed to $9 \%$ over 25 years old.

The change towards the sunna among young women appears to be strongest in the semi-city communities and weakest in city communities. The city communities selected included some with high concentrations of internally displaced people where access to education is low, which might explain why the move towards the sunna is weaker in the city than the semi-city communities. Further research would be required to clarify this.

School attendance is linked to the type of cut a young woman undergoes, with those attending school more likely to undergo the intermediate or sunna cuts.

The age at which girls are being cut appears to be reducing with $79 \%$ of young women being cut aged 8 years or under.

Although the majority of young women are still being cut by a traditional cutter, there is evidence of increased medicalisation of cutting with $14 \%$ of young women (aged $15-24$ years) being cut by a health worker, $10.5 \%$ of whom were cut by a trained health professional (nurse, midwife or doctor). The use of trained health professionals is higher among families where the girls attend school and university. The medicalisation of cutting is also more marked in city and semi-city locations where access to health professionals is higher. $21 \%$ of women have used a health professional to cut their own daughters, which confirms the move towards medicalisation.

Some health professionals who are cutting young girls have explained that they do so in order to avoid more damage being done by the girls being cut by non-health care workers. There is evidence of blame between health professionals and mothers as to who is responsible for the continuation of the use of stitches with both claiming it is the wish of the other.

\subsection{Complications of female genital cutting and access to clinical and support services (Objective 4a)}

98.9\% of women interviewed had been cut and of these, $59 \%$ had experienced complications shortly after being cut. The percentage of women suffering complications is considerably less (43\%) among young women aged 15-24 years, than among those aged $25-40$ years $(70 \%)$ or over 40 years $(85 \%)$.

Chart 10 shows the most commonly reported complications experienced. Although there was a higher incidence of long-term complications among those who had undergone the more severe forms of cutting, over half of women said they had experienced severe pain as a result of being cut, irrespective of the type of cut they had undergone.

Chart 10: Most commonly reported complications linked with undergoing female genital cutting

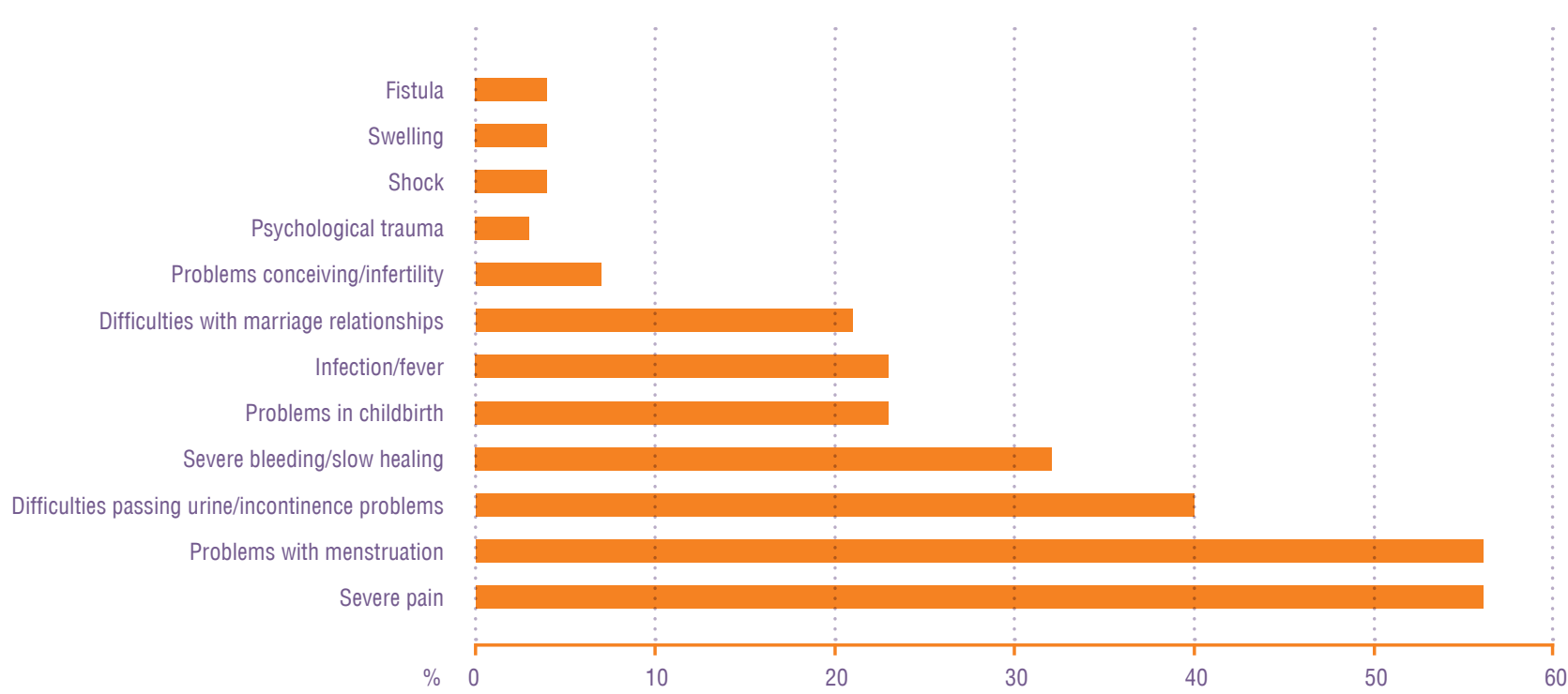


An even higher proportion (75\%) of women interviewed said that they have suffered long-term complications as a result of being cut. This was highest (77\%) among women who had undergone the pharaonic cut, however, $60 \%$ of those who said they had undergone the sunna said they had long-term complications. These complications tended to be problems with menstruation and infections.

Women who had undergone the pharaonic cut reported having a higher incidence of severe bleeding/delayed healing, difficulties in passing urine/incontinence problems, problems conceiving/ infertility, difficulties with marriage relationships and problems in childbirth (chart 11).

Chart 11: Differences in the complications experienced by women who had undergone the pharaonic, intermediate and sunna cuts

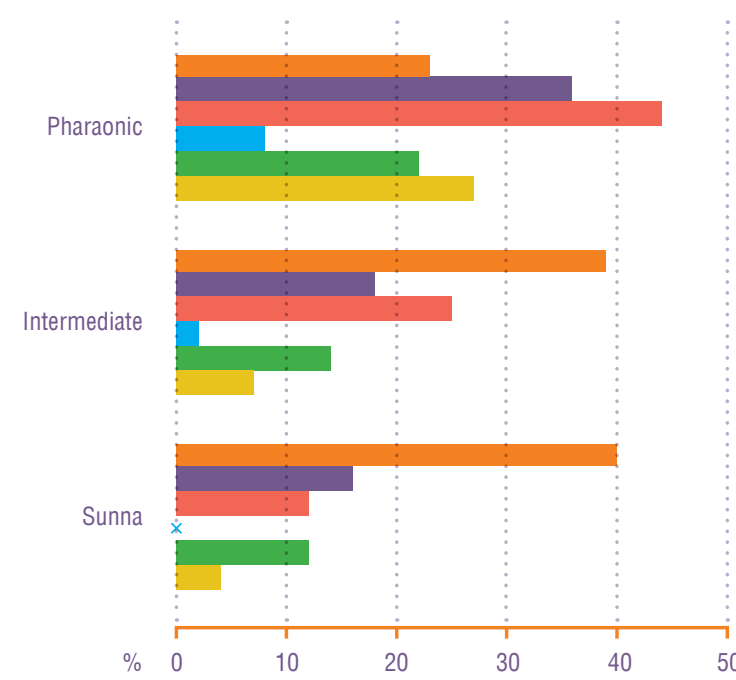

Key

No long term effect

Severe bleeding/slow healing

Difficulties passing urine/incontinence

Problems concieving/infertility

Difficulties with marriage relationships

Problems in childbirth
Two thirds (64\%) of girls and women who suffered complications after being cut sought support. This proportion is consistent across the age range and also across city, semi-city and village locations (chart 12 and chart 13).

Chart 12: Percentage of women who were cut, who suffered complication and sought support (by age)

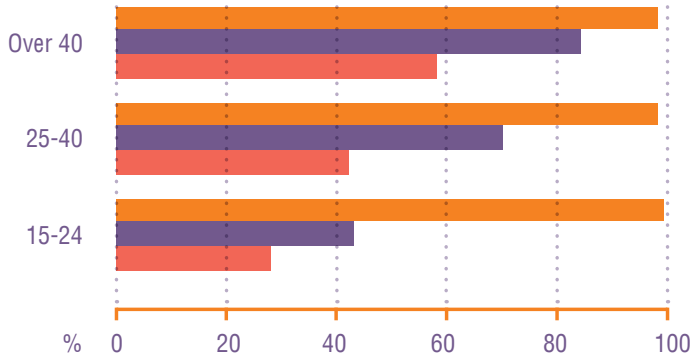

Key

Cut Complications Sought support

Chart 13: Percentage of cut women who were cut, suffered complications and sought support (city, semicity, village)

City

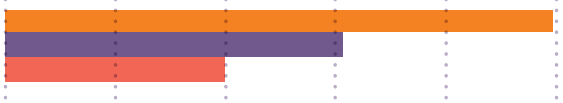

Semi-city

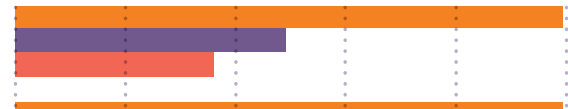

Village

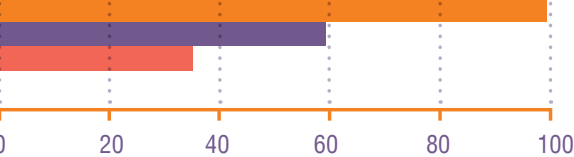


Chart 14: People and services where women sought support after being cut

Traditional healer

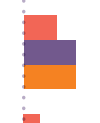

Hospital

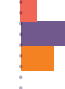

Pharmacy

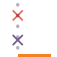

$\mathrm{MCH}$

$\stackrel{x}{1}$

TBA

$\dot{x}$
$\dot{x}$
$\dot{x}$

Traditional cutter

Religious leader

\section{Teacher}

Friend

Sister

Grandmother

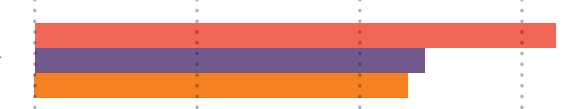

Mother

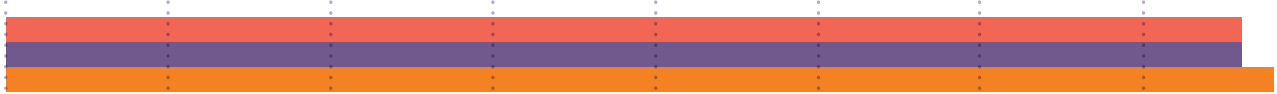

$\% \quad 0$

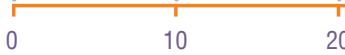

20

30

40

50

60

70

Key

Although two thirds sought support, fewer than $5 \%$ of these, sought professional support from a MCH, pharmacy or hospital (chart 14). Advice and guidance tends to be sought from within the family, from the mother, grandmother and sisters.

\section{Conclusion}

Over half (59\%) of women who had been cut had experienced complications shortly after being cut. This proportion is lower among young women (43\%) than among those aged $25-40$ years $(70 \%)$ or over 40 years (85\%). The decrease in the incidence of complications among younger women is likely to be a combination of undergoing a less severe cut and also changes in the conditions in which cutting is carried out, in particular the use of antiseptic, sterilised cutting tools and antibiotics.

Overall, $75 \%$ of women who were cut reported suffering long term complications. Problems with menstruation were reported among women who had undergone all types of cut. The four complications which were reported more frequently by those who had undergone the pharaonic cut were; severe bleeding/delayed healing, difficulties in passing urine/incontinence problems, problems conceiving/infertility, difficulties with marriage relationships and problems in childbirth.

Two thirds of those experiencing complications sought support. However, this was primarily from within their family. Fewer than $5 \%$ have sought advice and support from health facilities. 


\subsection{Knowledge of the types of cut and their effects on girls and women (Objective 2b)}

Overall, $96 \%$ of women and men interviewed knew that there were different types of cut, with almost all being able to describe the pharaonic and sunna cuts.

There were differences in the knowledge of the types between men and women with men being less aware of the intermediate/sunna2 (chart 15). However, $36 \%$ of young men (aged 15-24 years) were aware of the intermediate cut. This increased knowledge among young men is most marked in city and semi-city communities where the awareness of the intermediate type cut is approaching that of young women (chart 16).

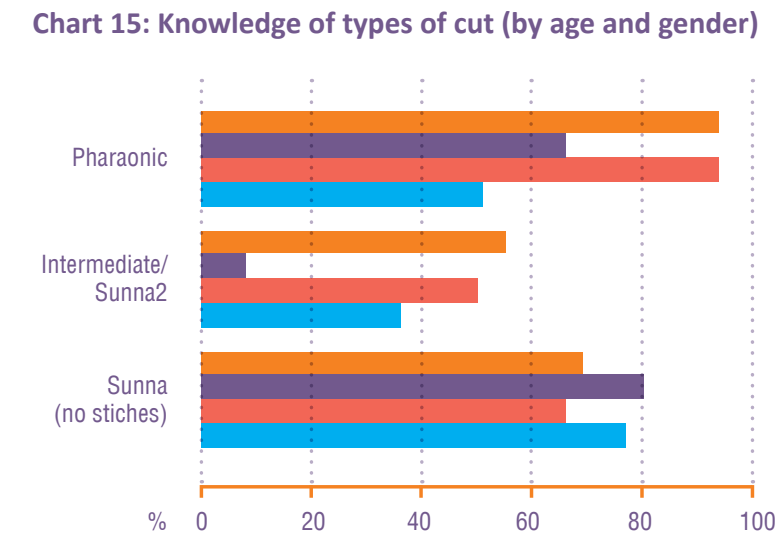

Key
Women all
Men all
Young women (15-24)
Young men (15-24)

Chart 16: Knowledge among young men of different types of cut (aged 15-24 years)

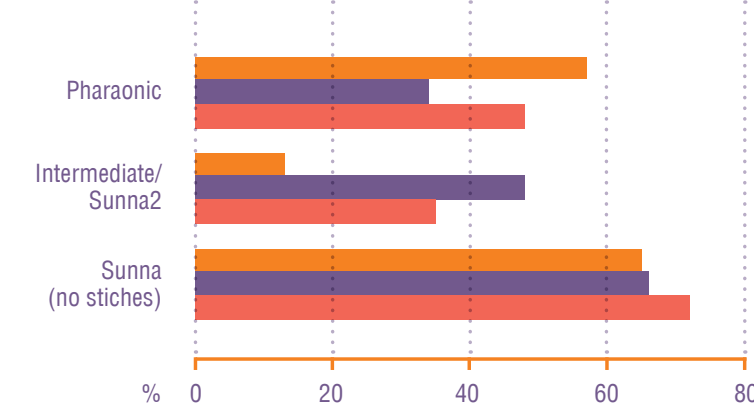

Key

Village Semi-city City
Knowledge of the effect of cutting with and without stitches on girls and women

The effects on girls and women of cutting with and without stitches are seen as markedly different. The overwhelming majority of women (80\%) and men (68\%) consider that girls and women suffer no harmful effects from the sunna (without stitches). The most frequently reported effects reported by women were severe pain $(7 \%)$, problems with menstruation $(6 \%)$ and difficulties passing urine (3\%).

There was general agreement between men and women that cutting with stitches (intermediate or pharaonic cuts) has a far greater effect than the sunna, with only $4 \%$ suggesting there are no harmful effects (chart 17). Twice as many women as men recognise that girls and women suffer from problems with menstruation (women 62\%, men 33\%), severe pain (women 41\%, men 22\%), difficulties passing urine (women $45 \%$, men $23 \%$ ) and infections/fever (women 29\%, men 14\%). Men report a higher incidence of difficulties with marriage relationships than women (men 25\%, women 15\%).
Chart 17: Knowledge of the effect of cutting with stitches

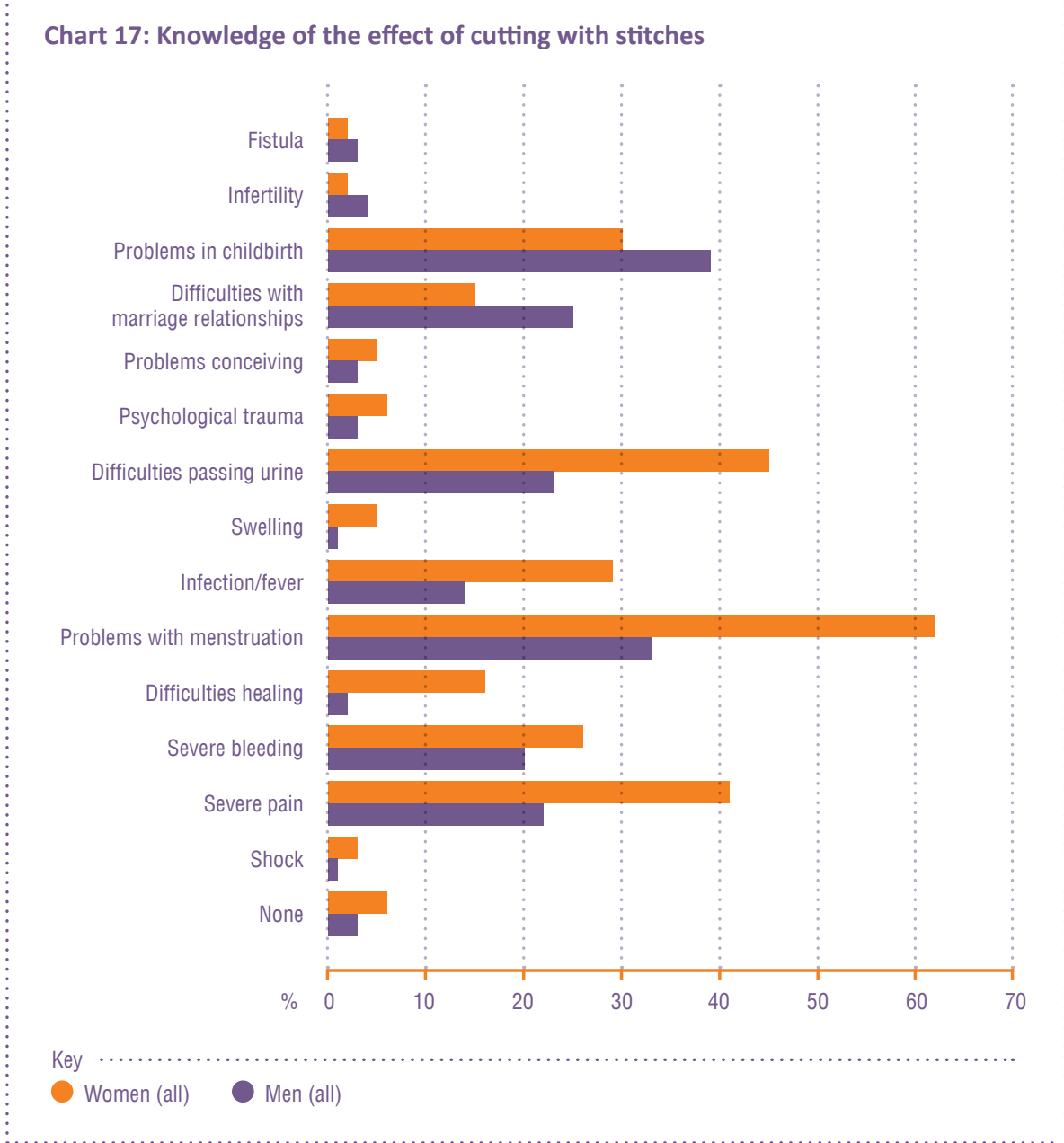

Key

Women (all) 
There were no significant differences in the awareness of the harmful health effects of cutting between people from different backgrounds (teachers, health workers, government workers, home-based people, farmers and traders), from people from city, semi-city and village communities, or between young and older women and men. Health workers used more technical language when describing the effects than, for example, farmers or traders. Men were more general in their descriptions than women. However, all groups were aware from their personal experience of the wide range of complications and the general types of health risks brought about by cutting.

\section{Conclusion}

Overall, $96 \%$ of women and men knew that there were different types of cut used in Somaliland. Most described the pharaonic and sunna cuts. The intermediate/sunna 2 cut was less well known with $55 \%$ of women and only $8 \%$ of men being aware of it, although this was higher among young men in city and semi-city communities (35\% and $48 \%$ respectively).

The majority of women (80\%) and men (68\%) considered that girls and women suffer no harmful effects from the sunna (without stitches), whereas only $4 \%$ suggested that there are no effects of cutting with stitches (intermediate and pharaonic). Twice as many women as men recognise that girls and women suffer from problems with menstruation, severe pain, difficulties passing urine and infections/fever from cutting with stiches. Men report higher incidence of difficulties with marriage relationships as a result of cutting with stitches.

\subsection{Messages heard on female genital cutting (Objective 2c)}

Overall, $72 \%$ of people interviewed had heard messages about FGC, with a significantly higher percentage (80\%) of men than women (65\%) (chart 21). This difference is consistent across all the age ranges (chart 18). Older women and men were more likely to have heard messages than younger ones. This finding is interesting given that FGC is considered to be the responsibility of women and not to involve men.

Chart 18: Percentage of women and men who have heard messages about female genital cutting

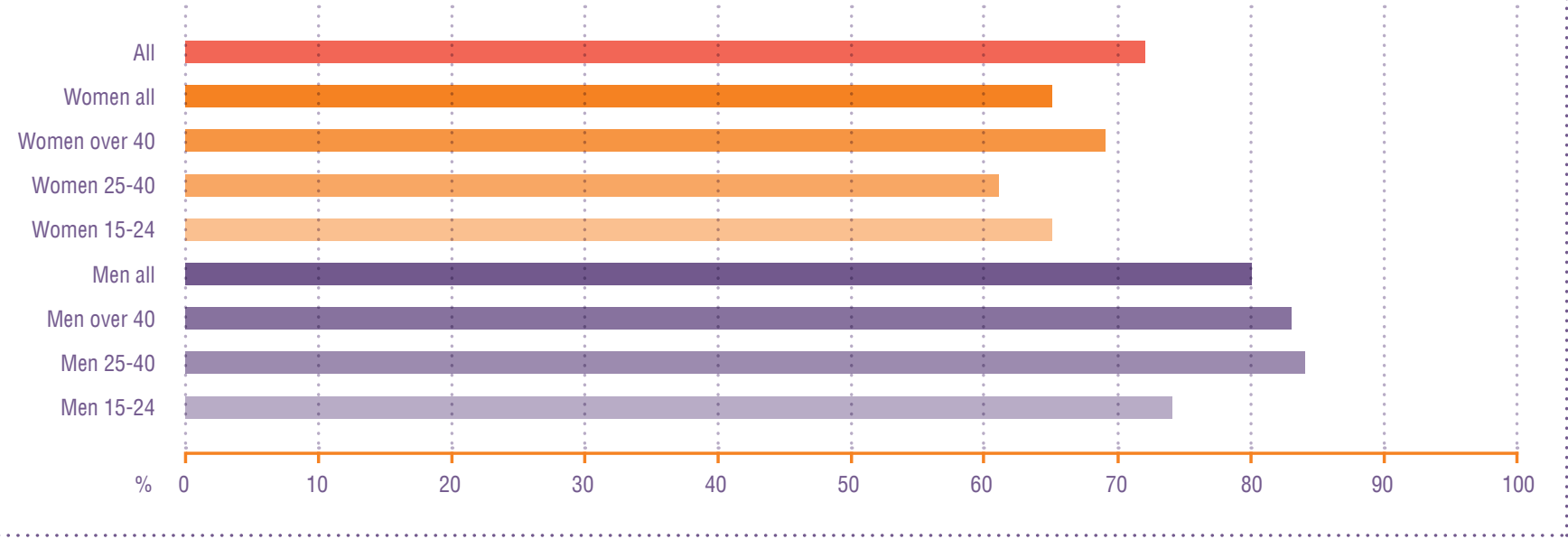

Chart 19 shows the percentage of people who have heard messages about FGC according to their role. Those least likely to hear about FGC are women, especially those at home. Farmers, fishermen and traders are also less likely to be involved in activities where people are exposed to messages about FGC than those working in education, health or government positions.

Chart 19: Percentage of people who have heard messages about female genital cutting (by role)

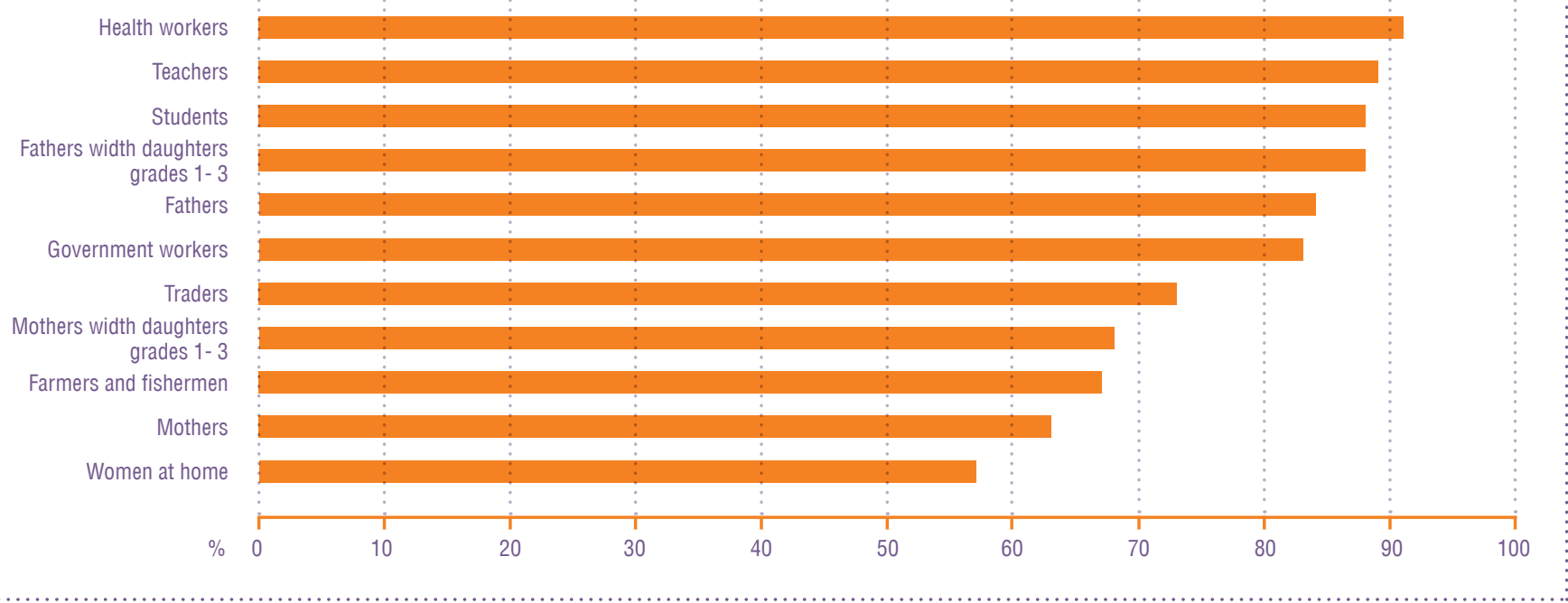


A higher percentage of people in city $(77 \%)$ and semi-city communities (74\%) have heard messages about FGC than in village communities (64\%) (chart 20).

Chart 20: Percentage of people who have heard messages about female genital cutting (city, semi-city and village communities)

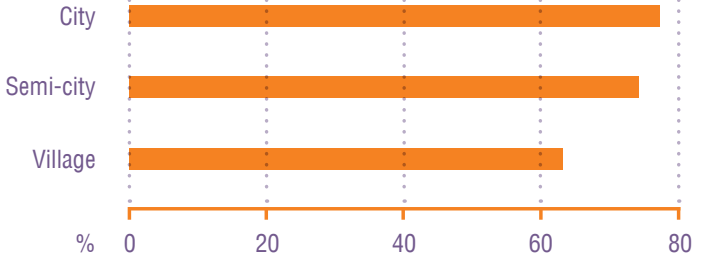

Chart 21 shows from where women and men are hearing messages about FGC. The most commonly reported source is the radio with $61 \%$ of men and $40 \%$ of women getting information on FGC from the radio. The next most common sources are TV, CSOs and health workers, especially for women, and public meetings for both genders. However, public meetings are only reaching $13 \%$ currently. Schools and the family are places where FGC is clearly not being talked about very much at all, with only $3 \%$ reporting hearing messages about FGC in their family and 5\% (7\% women and $3 \%$ men) in schools.

Chart 21: Source of messages on female genital cutting for men and women (overall)

$\mathrm{CSOS/NGOs}$

Government workers

Family

Health workers

Public meetings

Mosque

School

TV

Posters

Internet

Radio

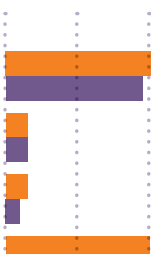

$$
\%
$$

$$
0
$$

Key

Women (all)
The most commonly heard messages are "the pharaonic cut is a crime against girls", heard by $61 \%$ of men and $49 \%$ of women (chart 22). Women are more likely than men to hear messages to abandon all types of cutting ( $22 \%$ for women as opposed to $1 \%$ for men). Interestingly, $21 \%$ of men reported having heard messages apparently from the media and NGOs "opposing the campaign against FGM", i.e. telling people to continue to cut their daughters despite the campaigning for Zero Tolerance. There were no reports of such messages being heard in the focus group discussion.

Chart 22: Types of messages women and men are hearing about female genital cutting

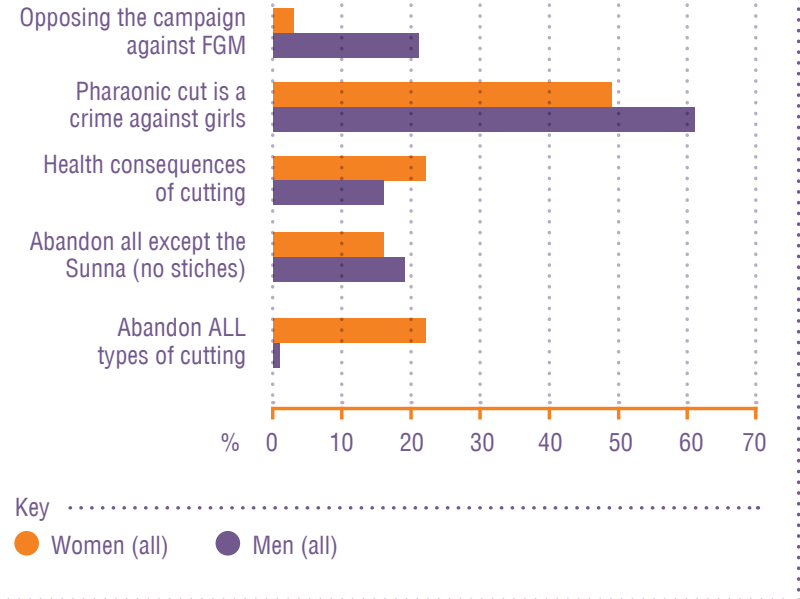


The differences between the sources from which teachers, health workers, government workers and religious leaders hear messages about FGC and those who are home-based, traders and farmers are relatively minor (chart 23).

It was clear in most of the focus group discussions, that although people have heard messages about FGC, most have not had opportunities to actually discuss how they feel about it with others.

\section{"This was never}

mentioned in school, never. In fact, this is the first time we have ever talked about it with each other... We have even been to some community meetings but we listened and that was all".

Community woman, Abdaal, Saaxil

\section{"there are some}

workshops where we go and get information but this [focus group] is the first time we have talked about what we believe and been able to hear different people's views and opinions."

Young man, city, Berbera

When people spoke in focus group discussions about moving away from the pharaonic, they said it was because they could see the effect the cutting was having on the girls and women in their community.

\section{Conclusion}

Almost three quarters of people have heard messages about FGC, with higher proportions of men than women being exposed to them and higher proportions in city and semi-city communities than in village communities. Those in professional roles (teachers, health workers, government positions) and students are more exposed to messages about FGC than women at home, traders, farmers and fishermen. Age is less important than gender or role.

The message most commonly heard is that the pharaonic cut is a crime against girls and women. Women are more likely to hear messages about abandoning all types of cutting than men.

Radio, NGOs/CSOs and TV are the most common sources of messages about FGC. Health workers and public meetings are the next most common source, although they reach less than $20 \%$. Family and schools are not places where messages about FGC are heard, although the family is where the decisions are made.
Chart 23: Source of messages on female genital cutting for employees and home-based/traders/farmers

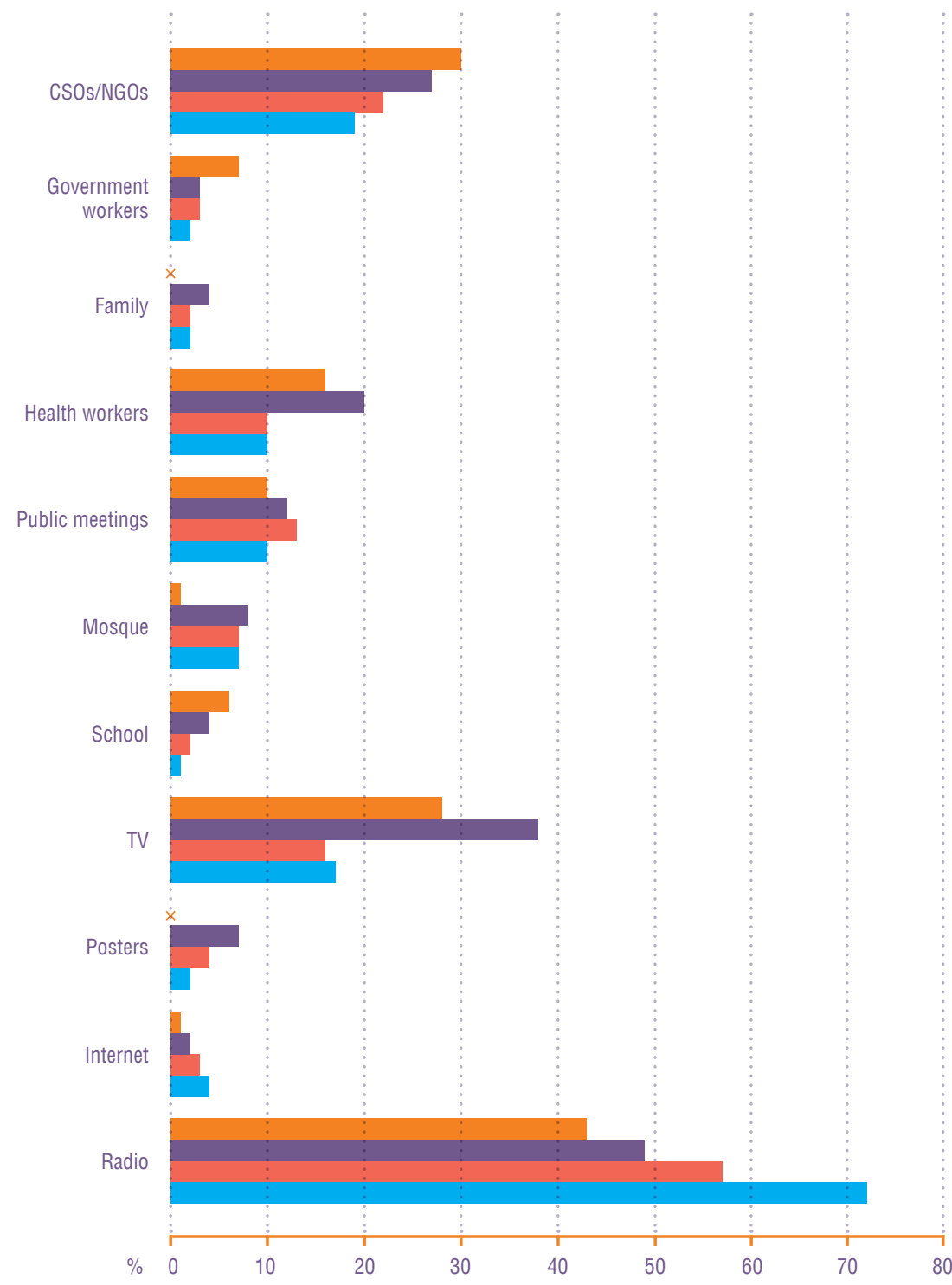

Key

Employees - teachers, health workers government workers (female) government workers (male)
Employees - teachers, health workers 


\subsection{Support for abandonment of female genital cutting (Objectives 2a and 2d)}

The support for abandonment was assessed by asking about participants' aspirations and intentions. All participants were asked what their intentions were for cutting any daughters they might have in the future and also whether they would prefer their future daughters-in-law to be cut and if so what type of cut. Unmarried men were asked what their preference would be for their future wife.

In addition, everyone was asked about their aspirations for the abandonment of cutting in their communities in the future.

Aspirations for future abandonment

Overall, only $10 \%$ of those interviewed said they did not want to see any abandonment of FGC and would prefer to see the current range of types of cutting continue. This leaves $90 \%$ aspiring to see abandonment in some form. Most (73\%) would like to see the abandonment of only the pharaonic type, $12 \%$ would like to see abandonment of both the intermediate and the pharaonic and just $5 \%$ would like to see the abandonment of all forms of cutting (chart 24).

\section{Chart 24: Aspirations men and women}

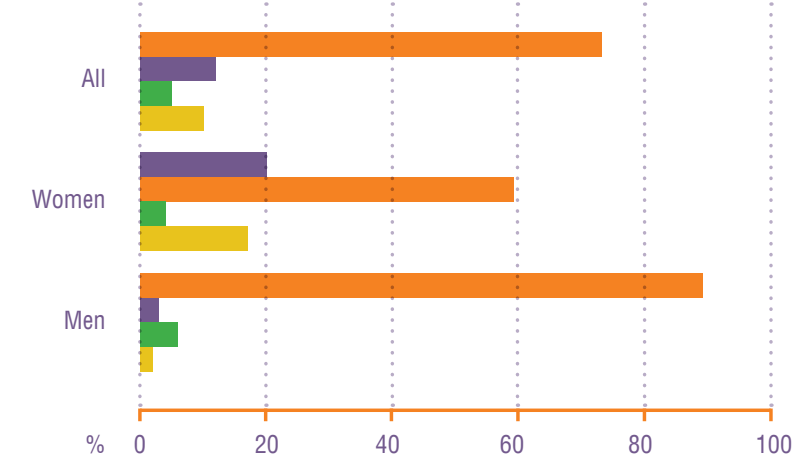

$\begin{array}{ll}\text { Abandon pharaonic } & \text { Abandon intermediate } \\ \text { Abandon all } & \text { Abandon none }\end{array}$

There is some difference between the aspirations of men and women. The overwhelming majority of men (98\%) want to see some abandonment and $89 \%$ want to abandon only the pharaonic. Women varied more in their responses with $17 \%$ wanting to see no change, $59 \%$ wanting to abandon just the pharaonic and $20 \%$ wanting to abandon the pharaonic and the intermediate, leaving $4 \%$ wanting to abandon all types of cutting.

The overall pattern of responses was similar across the age ranges, in village, semi-city and city contexts, among teachers, health workers, parents and among university students with some small variations (charts 25-30).
Despite more young women (aged 15-24 years) undergoing only the sunna cut, this age group does not appear to aspire to greater change in their community than older people (chart 26). In focus group discussions, young women were not very optimistic for change as they felt that cutting was deeply embedded in their culture.

"It is the older women who keep the pressure, so although I want to not do the pharaonic and maybe only do the sunna, but we also have to listen to the community. We cannot just decide on our own."

Community woman, village community, Saaxil

Female teachers and health workers seem to be more conservative about abandonment than their male counterparts (charts 27 and 28), reflecting the overall pattern (chart 24).

Chart 25: Aspirations men (by age)

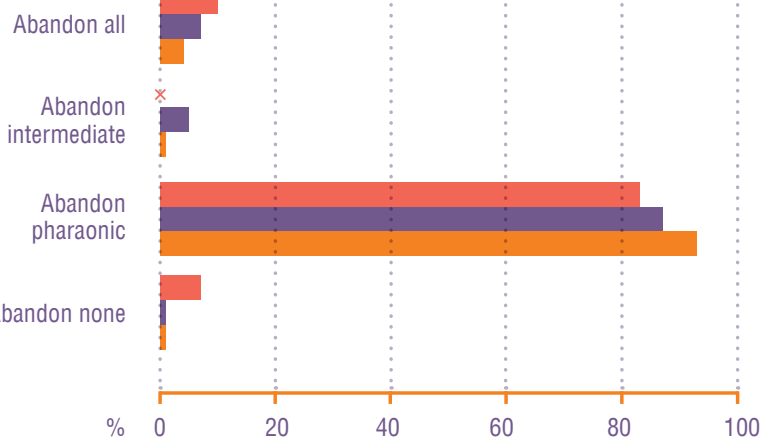

Key
$15-24$
$25-40$
Over 40

Chart 26: Aspirations women (by age)

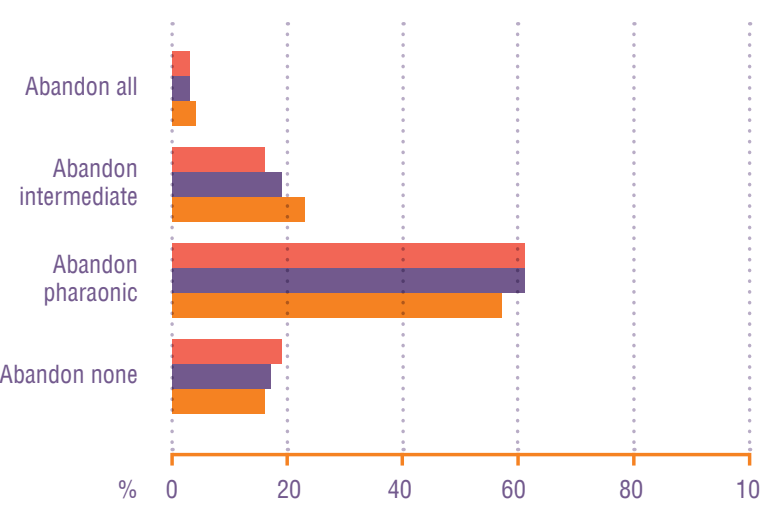

Key 


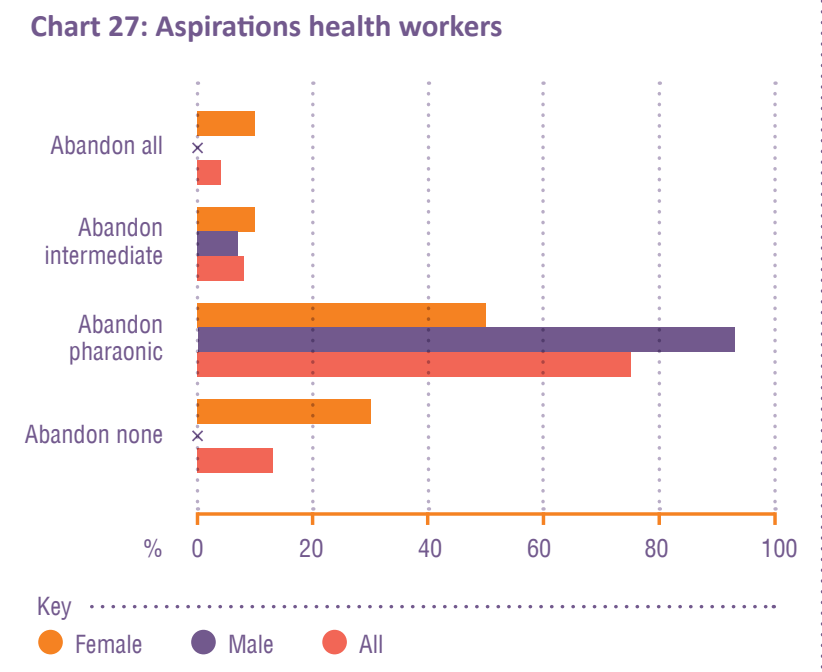

\section{Chart 28: Aspirations teachers}

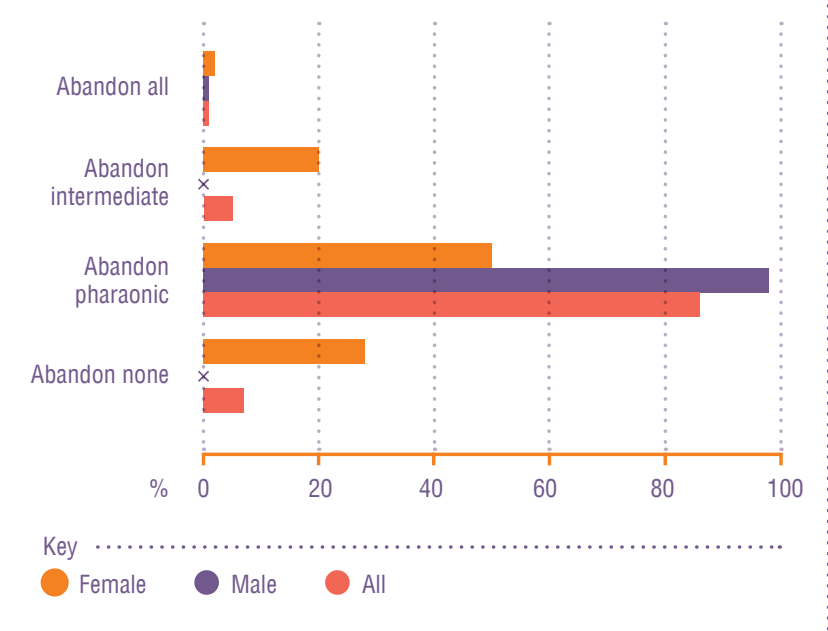

Chart 29: Aspirations university students

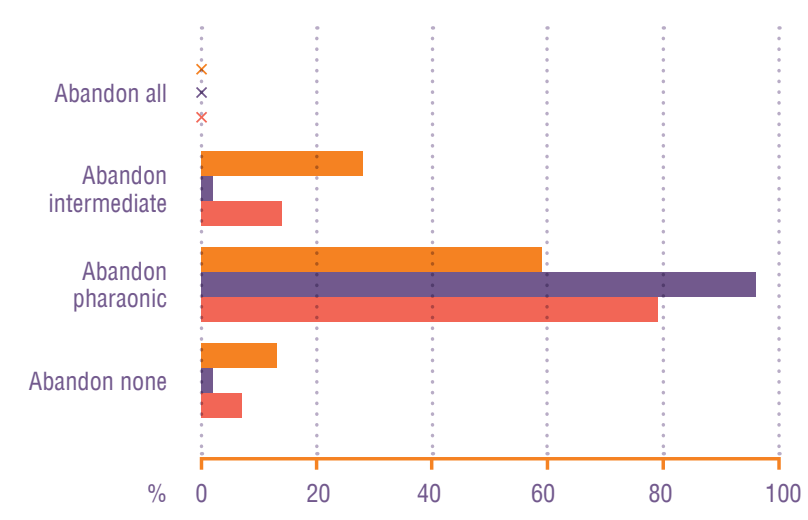

Key

Female Male All
Chart 30: Aspirations all (by city, semi-city, village)

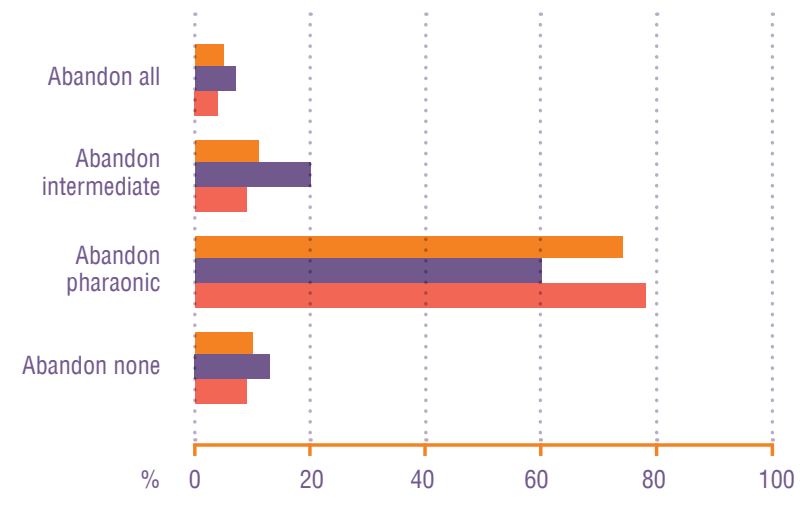

Key
Village
Semi-city
City

Intentions for future daughters

The majority of people (84\%) intend to cut their daughters in the future, with $62 \%$ intending to use only the sunna cut (chart 31 ).

Men favour the sunna more than women, although this is likely to be due, in part, to men not being familiar with the intermediate cut and viewing the choice as between the pharaonic and the sunna. Overall, $17 \%$ favour not cutting their daughters at all, with this being highest (24\%) among unmarried men.

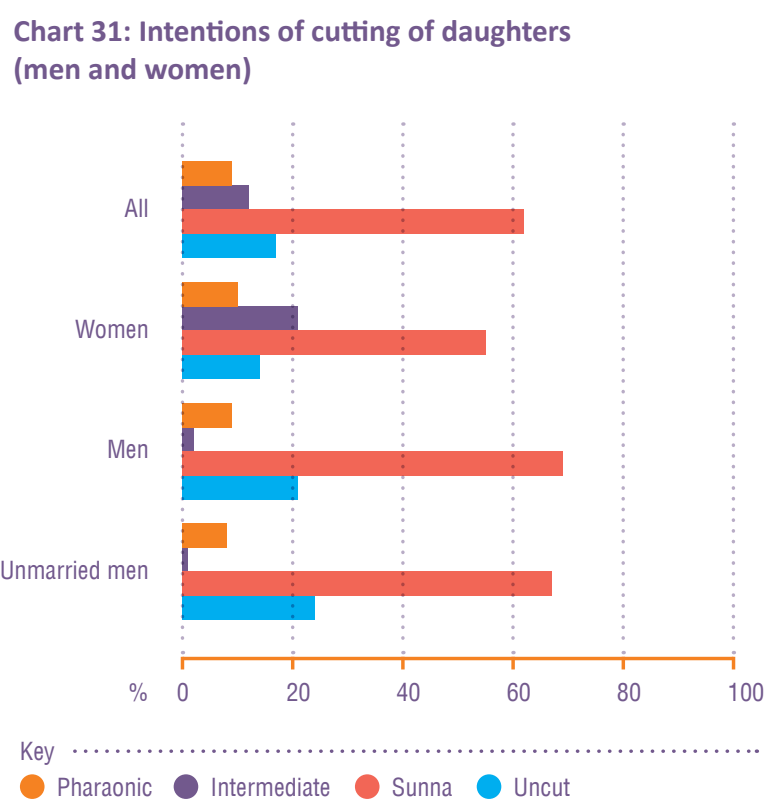

Young men favour not cutting their daughters more than older men and also more than young women, with $29 \%$ preferring their future daughters not to be cut (chart 32). Young women seem more traditional with a third (31\%) favouring a cut with stitches (the pharaonic or intermediate cuts). 


\section{Chart 32: Intentions of cutting of daughters}

(by age and gender)

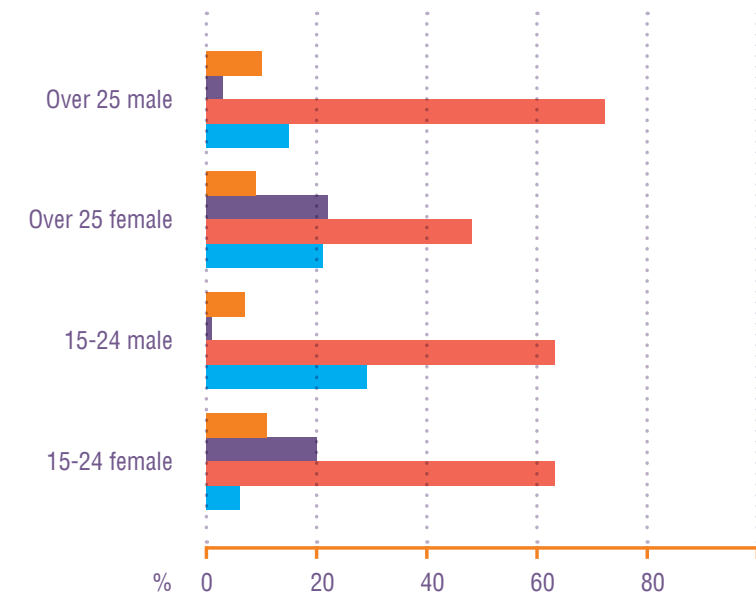

Key

Pharaonic

Intermediate

Sunna

Uncut

There is a similar pattern of intentions among people with different roles in the community (chart 33), although teachers and government workers are less likely to favour a cut which requires stitches than people who are home-based, farmers or traders (teachers $6 \%$, government workers $8 \%$, home-based, farmers and traders $24 \%$ ). $17 \%$ of health workers interviewed intend on using the intermediate cut for their daughters, although the sample size was small.

Chart 33: Intentions of cutting of daughters (by role)

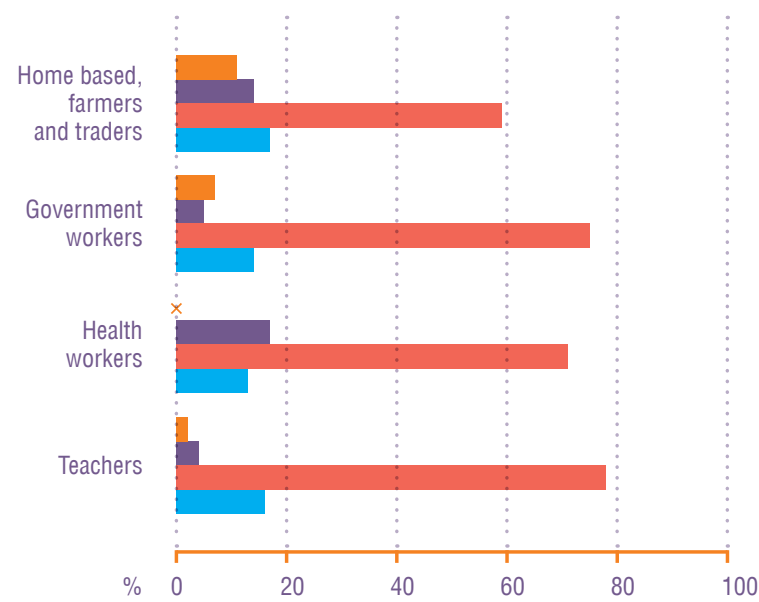

Key

Pharaonic

Intermediate

Sunna

Uncut

There is a link between participation in education and the future intentions of young women (15-24 years) in relation to FGC (charts 34 and 35). Young women who had not attended school were divided between wanting to retain all types of cutting (32\%) and wanting to abandon the pharaonic cut (68\%), whereas about a third of those who had attended school and university wanted to abandon the intermediate cut with some wanting to abandon all types of cutting. A similar pattern is seen when asked about their intentions for their own daughters; there is a progressive decrease in the proportion who intend their daughters to undergo the pharaonic cut and an increase in those who intend to leave their daughters uncut or for them to only undergo the sunna with no stitches. Surprisingly, none of the university students interviewed wanted to see the abandonment of all types of cutting.

Chart 34: Young women's intentions for their daughters

University

Secondary

Primary

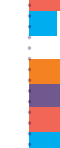

No school

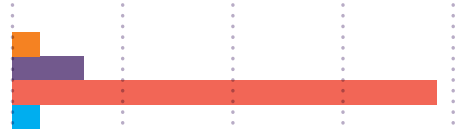

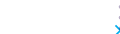

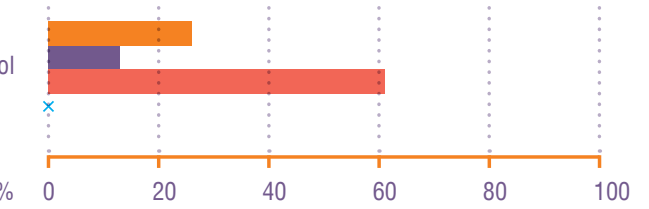

Key

Pharaonic Intermediate Sunna Uncut

Chart 35: Young women's aspirations for abandonment

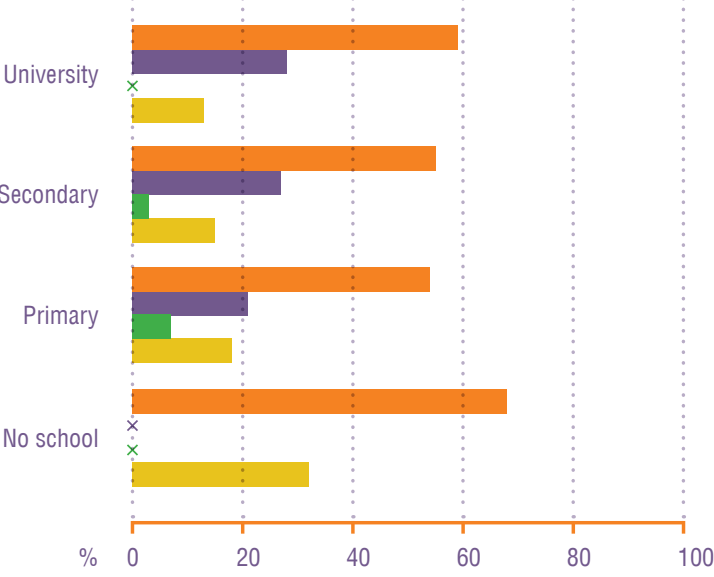

Key

Abandon pharaonic

Abandon intermediate

Abandon all

Abandon none

In focus group discussions, there was talk among men and women of the role of stitches to protect young women from the sexual attentions of men. Many felt that girls who had only undergone the sunna were more 'flighty', although others expressed the change more positively, for example, "life is life and it is good that young women can feel more and have sexual feelings and be satisfied". 
"Previously, after cutting girls were shy, they had no feeling, no conversation, they could not be persuaded into relationships easily. Nowadays with not so many girls undergoing the pharaonic cut, girls are not shy, they are easily persuaded and there are illegal children coming out all of the time."

Young man, city community, Saaxil

When asked whose responsibility it is to deal with this change, there was an initial recognition that both young men and young girls should take responsibility. However, this quickly turned to listing the ways that mothers should support their daughters. There were no suggestions of any actions on the part of young men.

\section{"Mothers should educate their daughters not} to have sex, girls should learn about sexual and reproductive health, religious leaders should educate the girls about the dangers of sexual relations before getting married, girls should be found a husband and married early enough to avoid 'illegal pregnancies'."

Young man, city community, Saaxil

\section{Intentions for future daughters-in-law}

When asked about whether or not they would prefer their future daughters-in-law to be cut, the majority of men (71\%) and women $(48 \%)$ said they preferred them to have undergone the sunna only (chart 36), with women again showing a stronger preference for the intermediate cut. Only $13 \%$ of people said they would prefer a daughter-in-law who had undergone the pharaonic cut. No-one responded that their daughters-in-law should be completely uncut. However, an additional category 'son decides' was included. This was selected by the remainder of participants ( $22 \%$ of women and $12 \%$ of men).

Chart 36: Preferences for the type of cut of their future daughters-in-law (women and men)
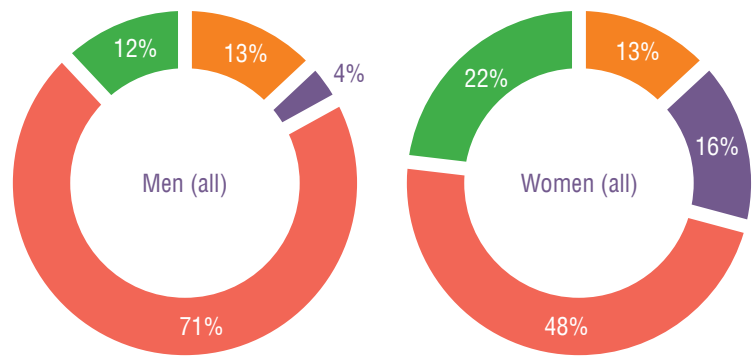

Key Pharaonic Intermediate

Sunna (none)

The following statement expresses the opinions of those who prefer the pharaonic or intermediate for their daughters-in-law.
"I want to know that my daughter in law has not been with another man and so the situation is not clear if she does not have the stitches."

Young woman, village community, Saaxil

However, it appears that the importance of proving virginity might be decreasing, at least in the city and semi-city communities, with the high proportion of those preferring their daughters-in-law undergoing the sunna only.

Attitudes of parents

SOFHA is particularly interested in the attitudes of parents, especially those with daughters in grades 1-3 at school. Chart 37 shows the aspirations of all parents interviewed and just those with daughters in school grades 1-3. The pattern is similar to the whole sample and other sub-groups with $73 \% / 69 \%$ respectively aspiring to the abandoment of just the pharaonic cut and 5\%/4\% aspiring to abandonment of all types of cutting respectively.

Chart 37: Aspirations of parents

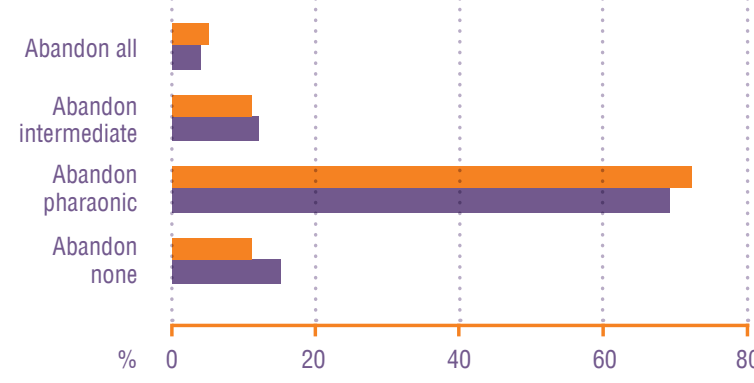

Key

All

With daughters grades 1-3

When parents were asked about their intentions in relation to the cutting of their daughters a complex picture emerges. Chart 38 shows the intentions for all mothers and all fathers and also for those mothers and fathers who currently have daughters in primary grades 1-3 who are as yet uncut. The pattern with fathers differs relatively little as to whether or not they have daughters at the age at which girls are usually cut. However, mothers whose daughters are at the age at which most girls are being cut, differ in their intentions from mothers in general. None of those making decisions currently intend for their daughters to remain uncut. Half (51\%) will undergo the sunna, a third (32\%) the intermediate and $17 \%$ the pharaonic.

These findings suggest that a quarter of mothers would like to see their daughters uncut, but when faced with the actual decision, they move to a more cautious position and decide to have their daughters undergo the sunna.

However, if the intentions of mothers with daughters in grades 1-3 (chart 38) are carried through to action, this will still represent a further move away from the pharaonic towards the sunna, in comparison with the young women (15-24 years) interviewed where approximately equal numbers of young women have undergone the pharaonic, intermediate and sunna cuts (chart 2). 
Chart 38: Parents intentions of cutting their daughters
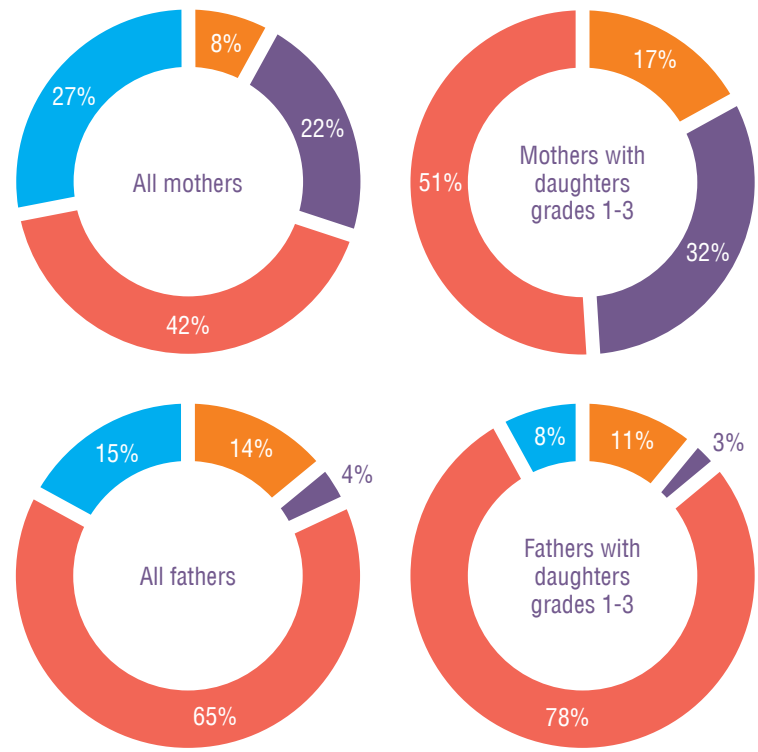

Key

Pharaonic

Intermediate

Sunna

Uncut

In one of the focus group discussions, in Berbera city, a similar pattern was seen. An older, well-educated woman had been involved in Zero Tolerance campaigns and declared that, "in 3 years we can reach Zero Tolerance when everyone will stop all types of cutting, even the sunna". The younger women in the group did not openly disagree with her. However, when the young mothers with daughters in grades 1-3 were asked about their intentions for their daughters they said they would be using the sunna as they wanted their daughters to be "pure to be able to marry freely".

When asked about their preferences for their daughters-inlaw, none of the parents wanted them to be completely uncut, however, $20 \%$ of mothers and $12 \%$ of fathers would allow their sons to decide (chart 39). In the focus group discussions, there was a tendency among those community women who wanted to see the greatest change to allow their sons to make the decision about who they marry, as opposed to those who favoured the pharaonic who expressed that as a preference for their daughters-in-law.

During focus group discussions, women in several communities felt that their husbands were resisting change as illustrated in the statement below.

\section{"Fathers want the more traditional cut, the} pharaonic cut, it is us mothers who want to change but sometimes we are forced into the pharaonic cut. It is causing serious disagreements between mothers and fathers."

Community woman, Abdaal, village community, Saaxil

This statement appears contrary to the findings about the attitudes of men (chart 25), however, it likely to be more a result of the lack of communication about FGC and misunderstandings about the attitudes of others.
Chart 39: Parent preferences for the cutting status of their daughter-in-law
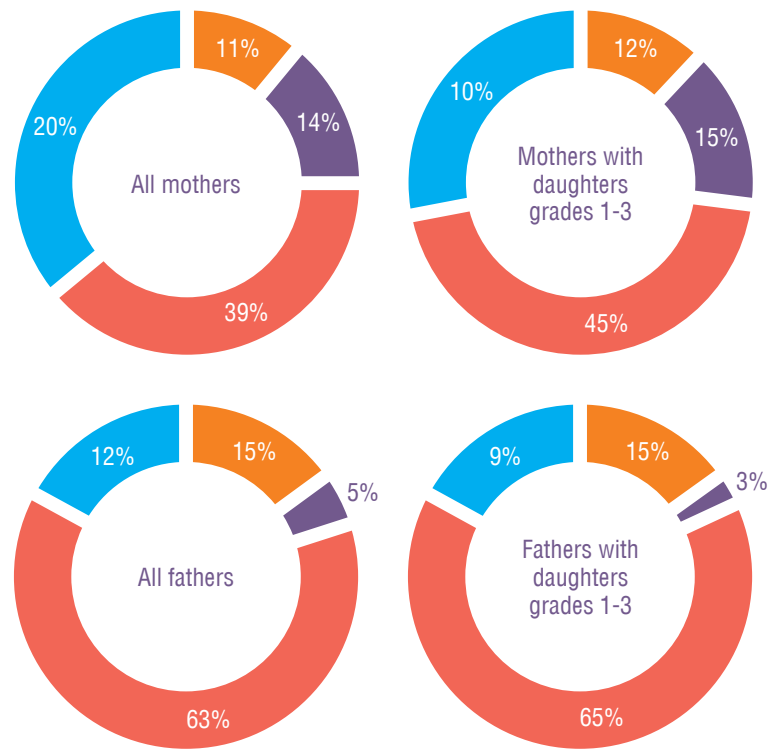

Key

Pharaonic Intermediate Sunna Uncut

Conclusion

Overall, $90 \%$ of those interviewed would like to see some abandonment of cutting in their communities, although only $5 \%$ would like to see the abandonment of all types of cutting. Men are less familiar with the intermediate cut than women and see the choice between the pharaonic and sunna, with $89 \%$ wanting to abandon only the pharaonic. Women are varied more in their responses with $17 \%$ wanting to see no change, $59 \%$ wanting to abandon just the pharaonic, $20 \%$ to abandon the pharaonic and the intermediate, leaving $4 \%$ wanting to abandon all types of cutting.

The majority of people (84\%) intend to cut their daughters in the future, with $62 \%$ intending to use only the sunna cut. This represents a stronger move from the pharaonic cut to the sunna in people's personal intentions than their overall aspirations for their community. Young men were the group who favoured not cutting their daughters most with $29 \%$ saying they would prefer their future daughters not to be cut at all. This was in contrast to young women where only $6 \%$ said they did not intend to cut their future daughters.

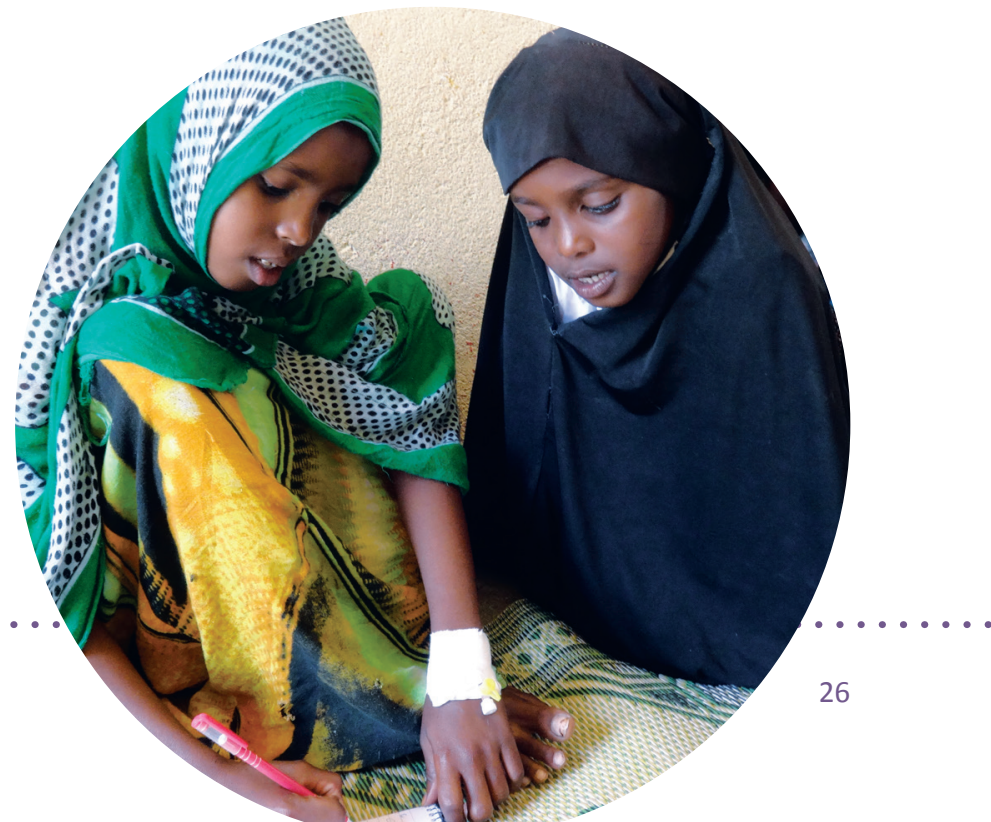




\subsection{Attitudes of young people}

Young men (aged 15-24 years) have a greater understanding of the types of cuts which young women are undergoing in their communities than older men (chart 40). This is likely to be a result of greater use of the media to disseminate information about FGC (see section 3.4). They were also aware of a wide range of harmful effects of cutting (see section 3.3), even though they were not usually involved in conversations about these in their families. This suggests that young men are more likely to be able to engage in meaningful conversations with their future wives about the cutting of their own daughters than their fathers.

Chart 40: Knowledge of types of cut (by age and gender)

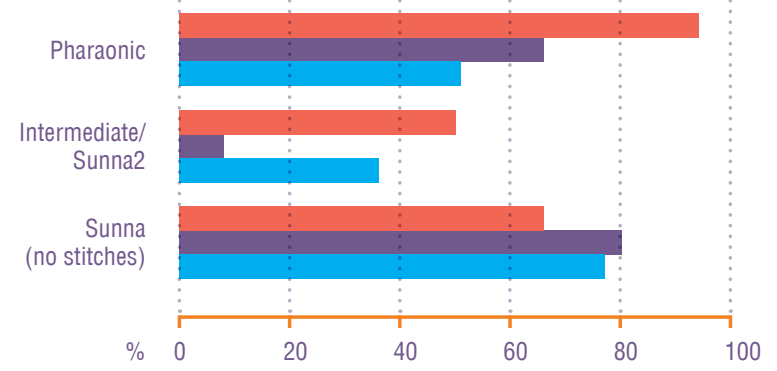

Key

Young women (15-24) All men Young men (15-24)

The majority (96\%) of the young men interviewed were unmarried. When asked about their preferences for their future wives, $89 \%$ said they would prefer to marry a young woman who had only undergone the sunna, with just $3 \%$ saying they would prefer a young woman who had not been cut at all. Overall, $84 \%$ of young men said that the type of cut their prospective wife had undergone mattered in their choice of wife. This was most pronounced in the semi-city communities (chart 41). $81 \%$ said they would ask their prospective wife directly themselves about this very sensitive issue.

Chart 41: Young men's opinions on the importance of the type of cut their future wife has undergone

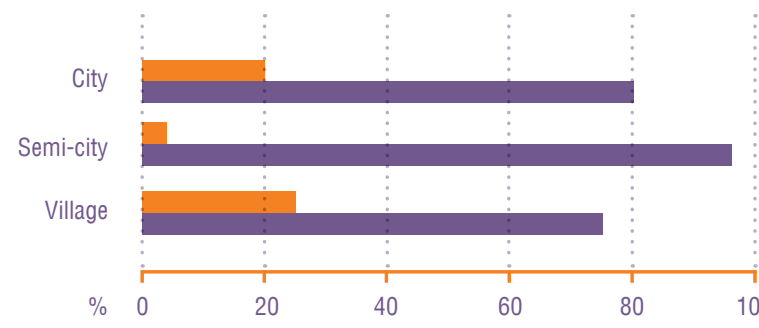

Does not matter

Does matter

In focus group discussions, young men drew a strong distinction between women who had only undergone the sunna and those who had not been cut at all. Many of the young men said they "would prefer to marry a girl who could feel". However, when asked if they would marry a girl who had not undergone the sunna, they were clear and unanimous:

"Definitely not. This is not part of our religion, no-one is not sunna in Somaliland. Girls must have sunna, it's religious."

Young man, city community, Booroma

The reaction was equally strong when young men were asked if they knew of any young women in their community who were uncut:

\section{"Absolutely no-one, this would not be acceptable and would bring shame. There is no-one in our community who has not even undergone the sunna. This would be completely against Islam."}

Young man, city community, Berbera

However, in the survey when young men were asked confidentially about their intentions in relation to their own daughters $29 \%$ said they would prefer their own daughters not to be cut at all with a further $63 \%$ preferring their daughters to only undergo the sunna cut (chart 42). This differs from the opinions of young women where $11 \%$ would prefer them to undergo the pharaonic and $20 \%$ the intermediate, giving a total of $31 \%$ intending their daughters to undergo a cut which requires stitches.

\section{Chart $\mathbf{4 2}$ Intentions of cutting of daughters} (young men and young women)

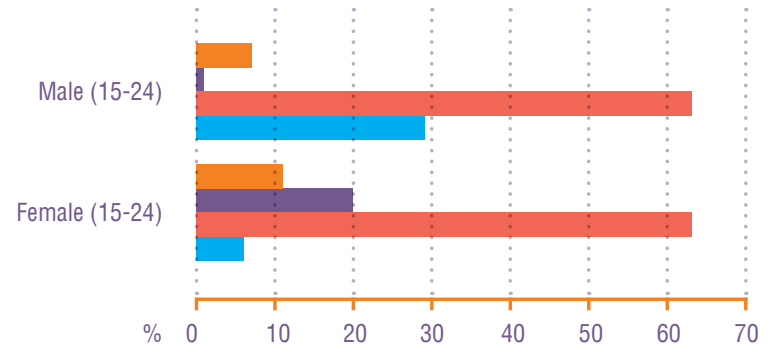

Key

Pharaonic Intermediate Sunna Uncut

Young men and young women have similar aspirations for their communities to older men and women. The overwhelming majority would like to see some change, although $16 \%$ of young women interviewed oppose any change. $93 \%$ of young men would like to see just the pharaonic cut abandoned and $4 \%$ want to see all types of cutting abandoned. Young women are showing a more stepwise movement from the pharaonic to the intermediate to the sunna (chart 43). 


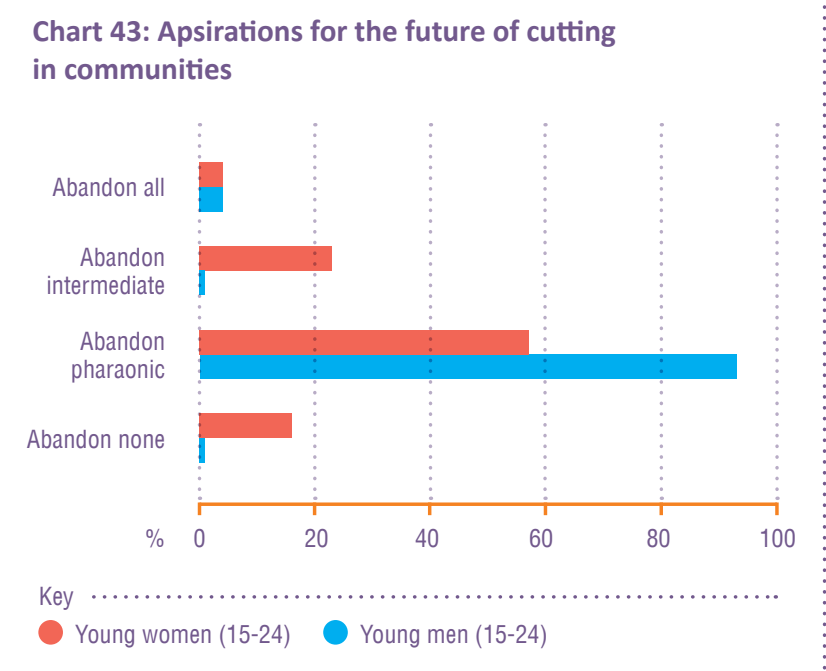

Overall, young people were inclined towards change, however, in the focus group discussions, there were young women and men who continue to support the cutting and were confident and articulate in their views.

\section{"It is necessary and the pain is a good thing, if it was only the sunna with 2 stitches and not the pharaonic cut."}

Community woman, Abdaal village, Saaxil

\section{"The process of going through the pain develops stronger women able to be mature and cope with the pain of being a mother."}

Young woman in secondary school, age 16, Booroma

\section{"It is part of our culture and we should not just stop it because of pressure from the West... I seem to be the odd one out here. I am actually thinking of starting up a group for the first type of cut [pharaonic]"}

\section{Involvement in activities to reduce female genital cutting}

Currently $40 \%$ of young men and $23 \%$ of young women say they are involved in activities to reduce FGC in their communities with $87 \%$ and $75 \%$ respectively saying they would like to get involved in the future (chart 44$)$. Only $18 \%$ of these young people came from villages, with over half coming from city communities.

Chart 44: Young people's current involvement in activities to reduce female genital cutting and future intentions$$
\text { Young men }
$$

Young women

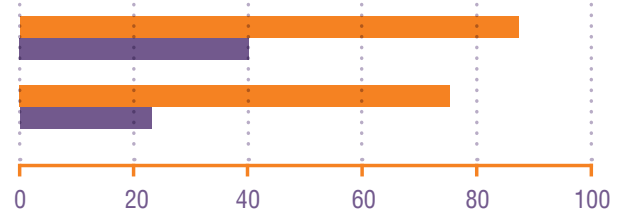

Key

Future involvement

Current involvement

Chart 45 shows the sorts of activities young people reported to be involved in. $17 \%$ of young men reported being involved in community health outreach activities. Young men were also more likely to have been involved in workshops. The next most common activity against FGC that they participated in was public meetings.

Chart 45: Types of activities to reduce female genital cutting that young people are currently involved in

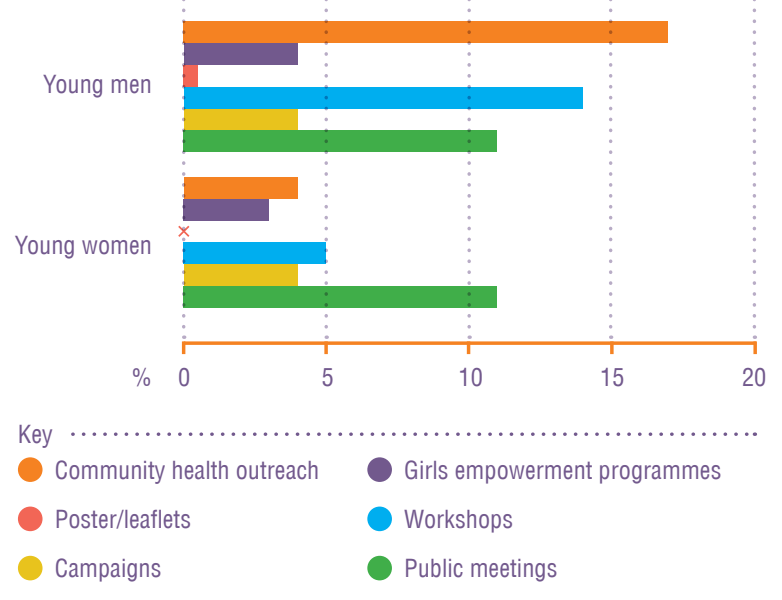


The most common barriers to becoming involved were not knowing what to do, fear of being ridiculed, fear of not being listened to and not understanding the culture around FGC as they were not involved in conversations in the family.

Chart 46 shows the kinds of activities which young people said they would like to get involved with in the future. The high proportion of young people wanting to advise parents reflects the weight of decision-making power held by parents. A third of young people want to speak in schools, which is a forum where there are currently relatively few opportunities for young people to talk about FGC.

\section{Conclusions}

With young men being more informed than previous generations and also expressing a distinct preference towards cuts which do not require any stitching, or no cut at all, young men would appear to be potentially important stakeholders in the campaign towards abandonment.

There appears to be a contradiction in the opinions expressed by young men in focus group discussions and in confidential interviews. When interviewed individually, $29 \%$ of young men said they would prefer their daughters not to be cut at all. However, in focus group discussions the overwhelming opinion was that not being cut was completely unacceptable in their community. This difference could be due to the group pressure to agree with the accepted social norm, that FGC is expected among all women in the community.

Young women and men are more than twice as likely to be involved in activities against FGC in city and semi-city communities than in village communities.

\subsection{Attitudes of teachers and the role of schools in abandoning female genital cutting}

This section includes the findings from the interviews with teachers and education officers, followed by an example of a school which has adopted a whole school approach to FGC.

A total of 209 teachers were interviewed in 22 communities in the 5 regions of Awdal, Maroodi Jeex, Sanaag, Saaxil, Togdheer. Chart 47 shows the number interviewed per region. In village communities, only $10 \%$ of teachers were female as opposed to $36 \%$ and $28 \%$ in semi-city and city communities (chart 48 ). Two thirds $(65 \%)$ of teachers interviewed work in primary schools, $27 \%$ work in secondary school and the remainder teach in Koranic and non-formal schools. The overwhelming majority of teachers interviewed $(89 \%)$ work in government schools with $11 \%$ working in private schools.
Chart 47: Number of teachers, male and female, interviewed per region

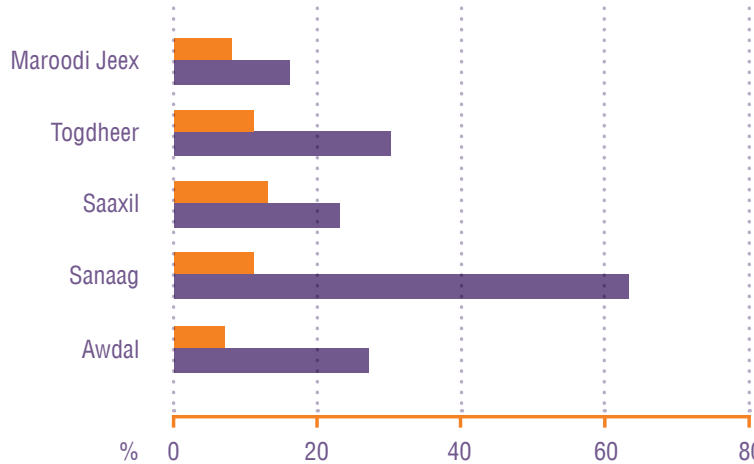

Key $\cdots . .$.

20
Male

Chart 48: Ratio of male and female teachers interviewed in city, semi-city and village communities
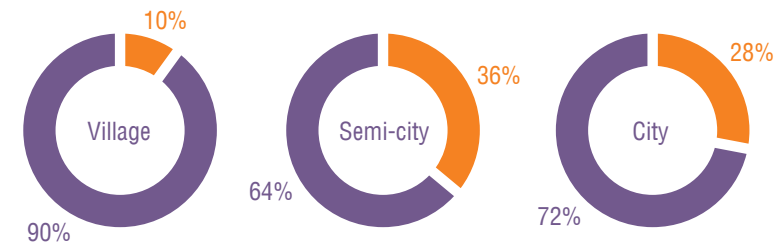

Key

Female 
Personal experience and attitudes towards female genital cutting

All of the female teachers had been cut, with $68 \%$ undergoing the pharaonic, $18 \%$ the intermediate cut and $14 \%$ the sunna. There is a trend away from the pharaonic towards the intermediate and sunna, with $100 \%$ of teachers over aged over 60 years and $82 \%$ of teachers aged $40-59$ years undergoing the pharaonic cut as opposed to just $50 \%$ of teachers aged $15-24$ years (chart 49 ).

$30 \%$ of male teachers interviewed were unmarried and of these $91 \%$ would prefer to marry a girl who has only undergone the sunna (without stitches). The majority were prepared to directly ask a girl they would like to marry whether or not she was cut.

\section{Chart 49: Types of cut undergone by teachers of} different ages

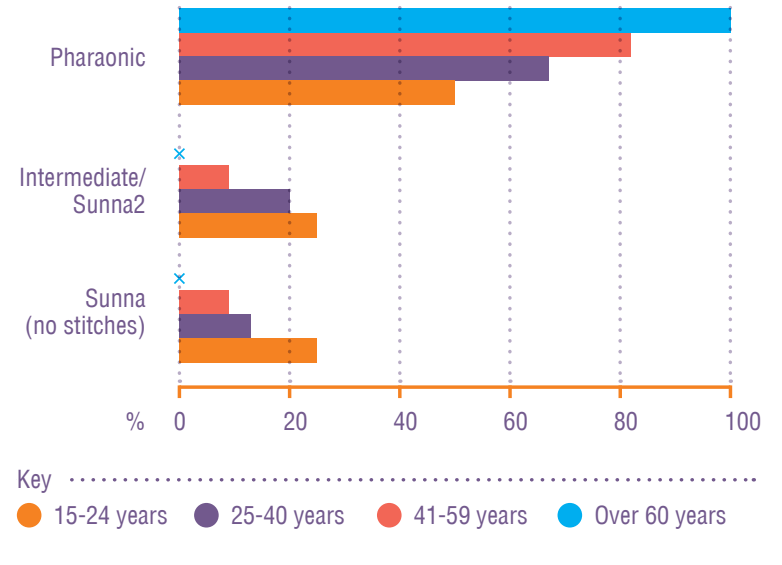

$62 \%$ of teachers were married. When asked about their preferences for their future daughters and daughters-in-law the majority would prefer them to have undergone the sunna with no stitches (charts 50 \& 51). Interestingly none said they would prefer their daughters-in-law to be completely untouched, however, $23 \%$ would prefer their own daughters to be untouched. There were no significant differences in the preferences of teachers in city, semi-city or village communities.

Chart 50: Married teachers' intentions for their future daughters

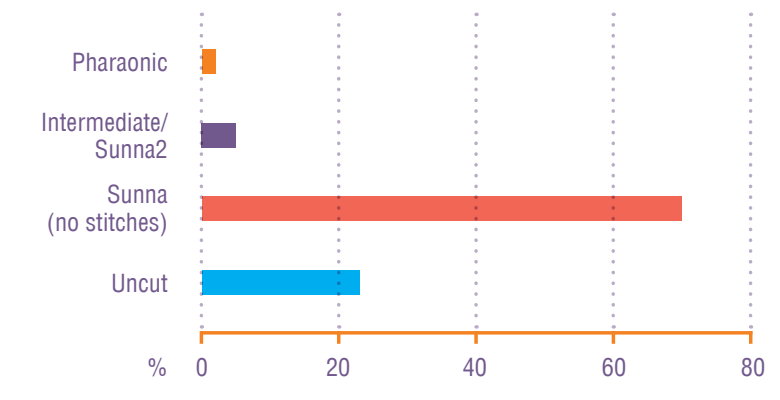

Chart 51: Married teachers' preferences for their future daughters-in-law

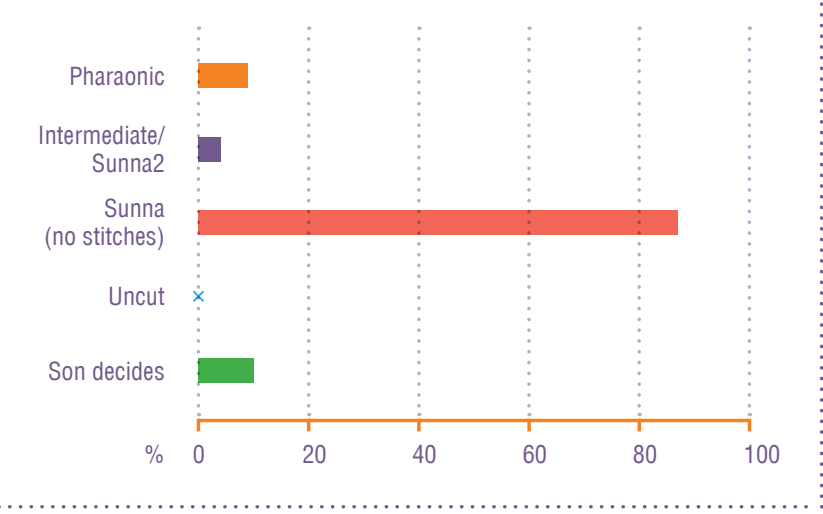

Teachers' opinions on the abandonment of FGC are broadly in line with those of the communities in which they work. Almost all (98\%) of male teachers would prefer to see the pharaonic cut abandoned in their community. The views of female teachers vary more with $28 \%$ wanting all types of cutting to continue, $50 \%$ wanting to see the abandonment of the pharaonic cut, $20 \%$ wanting to see the abandonment of both the pharaonic and intermediate cuts and $2 \%$ supporting the abandonment of all types of cutting including the sunna (chart 52).

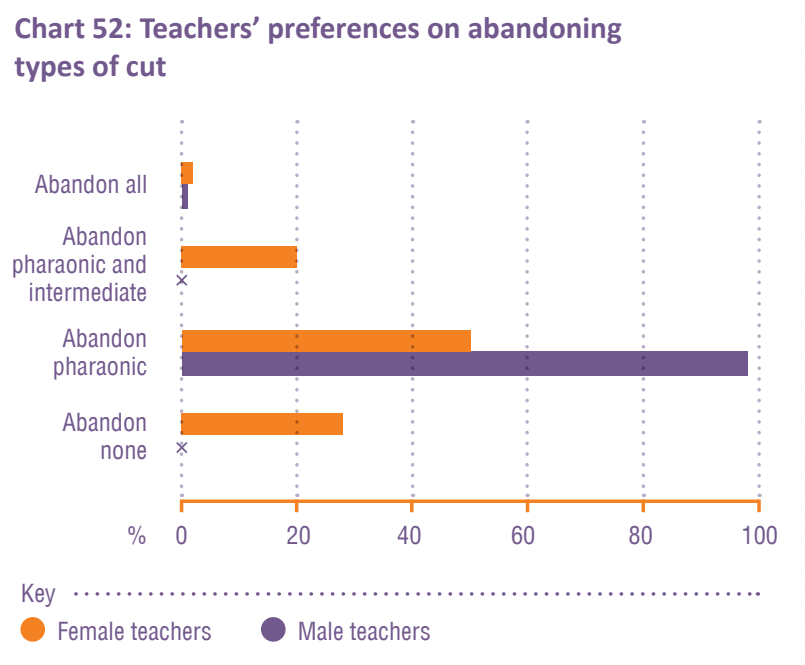

In focus group discussions, teachers expressed a wide range of views on FGC, reflecting the range of views across women and men in the community.

"The move towards the sunna only has led to an increase in C-sections which is not good at all. Women no longer know how to deal with pain and instead go for costly C-sections... when she marries the price of the girl is higher if she has been cut and closed properly - an open girl has a less good price."

Male primary school teacher, Berbera city 
"The other type [intermediate/sunna2] where they are closed only a little is ok. With the totally closed girls this is problematic when they get married and then they need to be open."

Principal, secondary school, Sheikh, Saaxil

\section{"We do not need to touch our daughters at} all, not even the sunna. I will marry whoever I marry but she does not need to be touched. If I have daughters they will not be touched, not at all. I cannot be persuaded from this."

Male primary school teacher, Saaxil

\section{"The pharaonic is dangerous and brings so many health complications. We must stop this cut totally. But it is our tradition to do the cut and so we can still do the small cut with just 1 or 2 stitches and the girls will not suffer the bad health for their lives."}

Female primary school teacher, Saaxil

With teachers holding such a wide range of views, it is inevitable that they will be giving contradictory messages to girls and parents when they do speak about FGC in schools.

Teachers' understanding of the role of schools in relation to female genital cutting

Teachers held a range of views about the role of schools in relation to FGC (chart 53). There were no significant differences between the views of teachers in city, semi-city or village communities, however, male and female teachers did have different priorities. The overwhelming majority $(84 \%)$ of teachers felt that schools should have a role in relation to FGC. Only $2 \%$ of teachers felt that the role of schools was to promote cutting with $29 \%$ seeing their role as speaking out against cutting. Male teachers are more likely to see their role as raising awareness among parents (28\%), whereas female teachers place a higher emphasis on providing opportunities for girls to learn about cutting (32\%).
Chart 53: Teachers' understanding of the role of schools in relation to female genital cutting

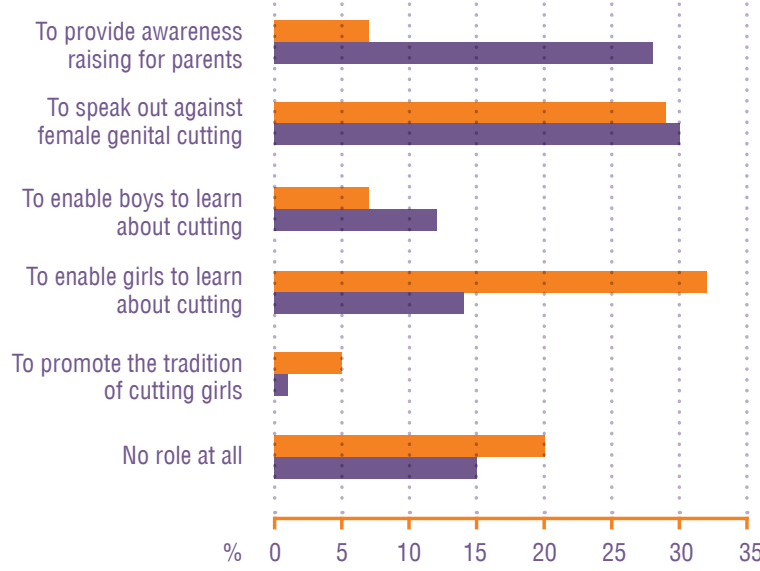

Key

$$
\text { Female Male }
$$

In focus group discussions, opinions were divided about the role that schools should play in awareness raising about FGC. Most were of the opinion that "schools must raise awareness, it is their role to support the community not just to teach", however a few felt that "schools should teach only, that is their role and they should stick to this".

Teachers talking about female genital cutting in schools

Despite $84 \%$ of teachers feeling that schools have a role to play in relation to $\mathrm{FGC}$, only $42 \%$ have actually talked about it in schools (chart 54). Perhaps surprisingly, a higher proportion of male teachers (55\%) report that they have spoken about FGC compared to female teachers (45\%). Teachers in schools in cities are less likely to talk about cutting, with only $33 \%$ doing so, than those in semi-city or village communities (55\%) (chart 55).

Chart 54: Teachers who have talked about female genital cutting in school (male/female teachers)

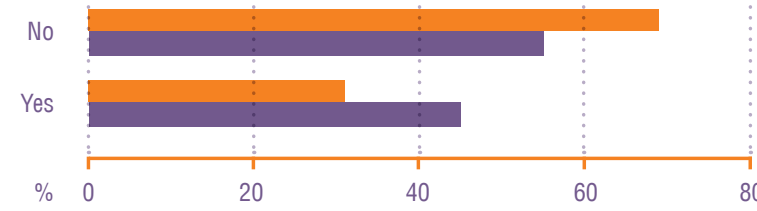

Key

Female teachers Male teachers

Chart 55: Teachers who have talked about female genital cutting in school (city/semi-city/village)

No

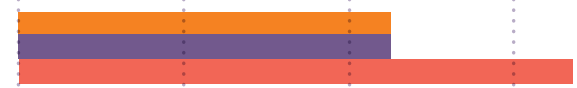

Yes

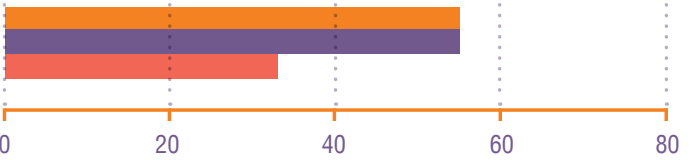

$\%$

80

Key 
Chart 56 shows the types of people that teachers are talking to about FGC. The cutting of the girls at school is not something which teachers talk to each other about with only $2 \%$ talking to other teachers. Male teachers are more likely to talk to groups of girls (22\%) and in classroom time (14\%). Female teachers tend to talk to both individual girls (18\%) and groups of girls (16\%). Only $9 \%$ of teachers have talked to parents about FGC, despite, $22 \%$ of teachers ( $7 \%$ female and $28 \%$ male) seeing this as being the role of schools.

In focus group discussions, teachers who would like to see reductions in FGC were reluctant to speak out.

\section{"I do not speak about FGM in my school as it is a primary school. If it was a secondary school I would speak to the girls and parents but it is inappropriate to speak about this in primary schools."}

Female primary school teacher, semi-city community, Awdal

Chart 56: Types of people teachers have talked to about female genital cutting

Whole school activities

In classroom time

With other teachers

With parents

With mixed groups of girls and boys

With groups of boys

With groups of girls

With individual girls

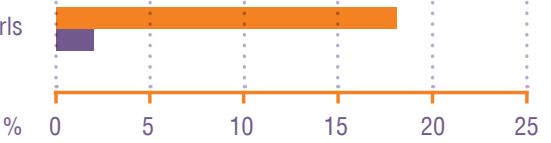

Key

Female teachers

Male teachers

Requests to teachers for advice

Female teachers are more likely to be asked for advice about FGC, however, only $43 \%$ have been asked as opposed to just $17 \%$ of male teachers (chart 57). There are no significant differences between teachers in city, semi-city and village communities. Where teachers do give advice the most common is explaining that not all girls are cut, giving advice on managing medical complications of being cut and offering to talk to parents (chart 58).

Chart 57: Percentage of teachers being asked for advice on female genital cutting

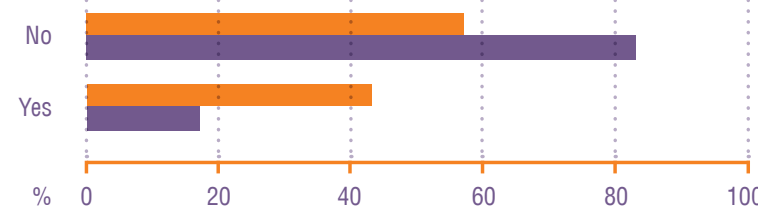

Key

Female teachers Male teachers

Chart 58: Types of advice given by teachers about female genital cutting

I tell girls not to be unkind to other girls

Offer to talk to parents

Explain parents are doing the best for them

Explain that not all
girls are cut

Advice about medical complications

None, it is not my role to give advice

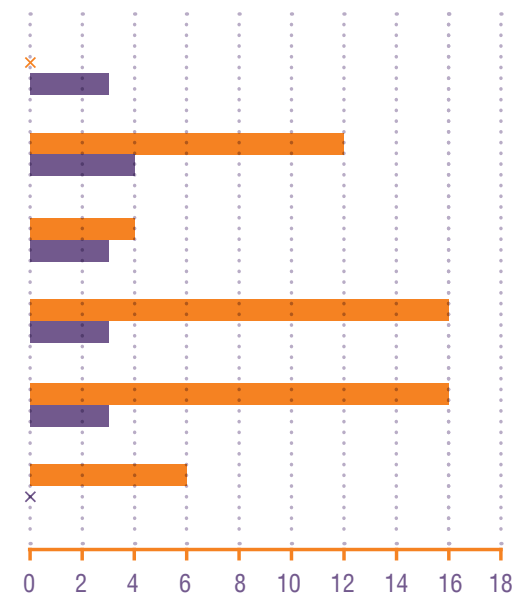

Key

Female teachers

Male teachers

Teachers taking action at school before holidays when cutting will take place

Approximately a quarter of teachers ( $27 \%$ of female teachers and $23 \%$ of male teachers) say that they take some kind of action in relation to FGC prior to the long school holidays when girls are most likely to be cut (chart 59).

Chart 59: Percentage of teachers who take action on female genital cutting before school holidays

No

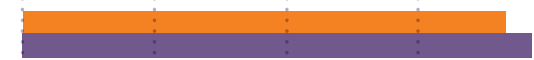

Yes

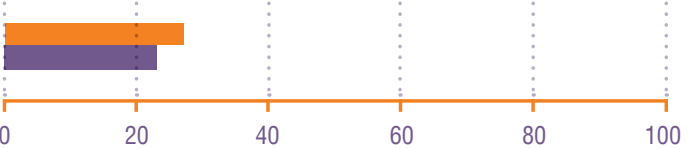

$\% \quad 0$

20 100

Key

Female teachers

Male teachers

The main activities which take place are talking to parents and girls, with no teachers talking to boys and few inviting religious leaders or health workers into schools (chart 60). Only 3 teachers appear to have interactive sessions, making plays or songs with pupils about the dangers of being cut. 


\section{Chart 60: Types of actions teachers take before a} school holiday

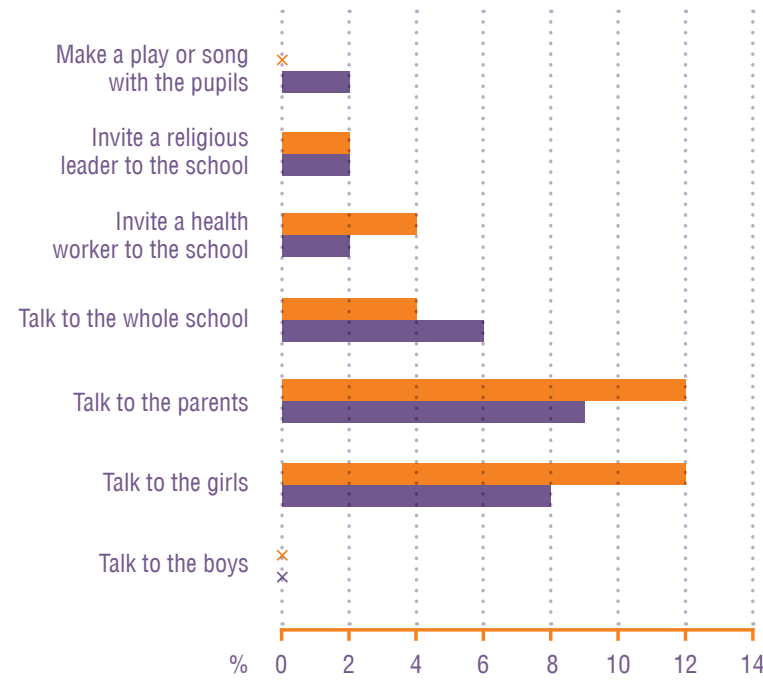

Key

Female teachers

Male teachers

Readiness of schools and teachers to play a significant role in the abandonment of female genital cutting

The Ministry of Education is committed to schools and teachers playing a strong role in the abandonment of FGC. However, with teachers holding a wide range of views, including some which strongly support the pharaonic cut, they are not yet in a position to provide a consistent and reliable message towards abandonment.

The Regional Education Officer in Berbera city explained the approach being taken by his department and the challenges the department face.

"We already have a gender focal person at regional and district level with a focus against all forms of violence and abuse against children. In future, they should also consider FGM but we are not there now."

\section{"Most of our teachers have had no training} at all on FGM and so are not ready to play a role. However, I think FGM should be part of the teaching training curriculum. It is not now, but in the future, it could be one of our crosscutting themes."

"Teachers in primary, secondary and tertiary level education should be trained on how to deal with FGM, they need awareness raising before they are able to take on this role. Both male and female teachers should become involved as this is an important issue for men as well as for women."
Similar views were expressed in focus group discussions about school teachers not currently being equipped to act as change agents on FGC:

"the teachers need awareness raising first, they do not understand the issues at the moment so it would be wrong for them to start without some training"

Community woman, Sheikh, semi-city, Saaxil.

Whole school approaches to female genital cutting

Most schools, both primary and secondary, do not have a policy on FGC or provide training for teachers on handling requests for support from girls or responding to parents. In some schools, some female teachers in particular have participated in workshops with Candlelight or the Adventist Development and Relief Agency (ADRA).

Where primary schools include FGC in sessions for girls on personal health and hygiene, it appears to be a relatively short session provided for girls usually in grades 5 - 6 . The main emphasis of the session is on explaining the complications of cutting to girls and persuading them to avoid being cut. However, by grades $5-6$, many, if not most, of the girls will have already been cut so the teachers will be talking to mixed groups of cut and uncut girls.

School nurses are not provided in government schools, although some individual schools have private arrangements. This means that girls cannot approach their school nurse for advice on cutting or on managing the effects of being cut.

None of the schools visited provided sessions on FGC for boys.

Several schools offer sessions for parents of girls on health and hygiene which include mention of FGC. The focus is on providing information on the complications of cutting and trying to persuade parents not to make their daughters undergo the cut.

One school in Hargeisa, reports a decrease in the number of parents requesting to take their daughters out of school to be cut, although they know that some of these girls are still cut, but in the school holidays. One of the teachers was given the title of Gender Focal Person with responsibility to support girl students to continue with their education and to resist early marriage and FGC. When parents request permission to take their daughters out of school, they are referred to the Gender Focal Person who explained:

"I tell them about the complications of FGM and try to persuade them not to cut their girls. And tell them the school does not make up any of the school work if they miss. It is the responsibility of the parents that they are missing their lessons." 
One school visited, Muse Ma'alesh Primary School, Sheikh, has developed a whole school approach to FGC.

\section{Muse Ma’alesh Primary School, Sheikh, Saaxil}

Muse Ma'alesh Primary School, established in 2015, under the UNESCO SOS Children's Villages initiative, with funding from UK aid. There are 391 girls in 6 classes, 10 teachers ( 5 male, 5 female) and a female principal.

The school has a strong focus on the rights of the child, with particular emphasis on domestic violence and the rights of the child in the family. It has an outreach programme which offers places to 90 girls from the most hard-to-reach communities in partnership with the Adventist Development and Relief Agency (ADRA).

Girls tend to be cut over the summer break (JuneSeptember). Traditionally all girls underwent the pharaonic cut, however, there has been a change in the last 5 years away from the pharaonic towards the intermediate (sunna2), with a few girls undergoing only the sunna (no stitches). There is currently a strong preference (80\%) among parents for the sunna2, identified through consultation meetings with parents. Cutting is performed in the girls' homes by a traditional cutter who is highly respected and performs the type of cut the parents request. Few girls, if any, are taken to the hospital to be cut.

The Principal says, "Girls who undergo the pharaonic cut tend to return late to school and have difficulties in settling back in. Previous high achievers often become shy, lack confidence and have trouble concentrating at first. They don't tend to drop out but are often changed permanently, behaviourally. The girls often feel bad about having been cut and the school's focus is on trying to support them in managing the difficulties and to avoid infections which might lead to more severe complications in the future."

The school brings parents in for meetings and discussions about the cutting of their daughters. These conversations are usually led by the Candlelight team, a CSO with expertise on FGC who promote abandonment of all types of cutting. Teachers also talk to the students about the health and hygiene aspects of being cut and how to deal with the complications and difficulties they are experiencing. These conversations also extend to the parents.

The Principal's personal preference is for the sunna only. The opinions of teachers range from supporting the sunna2 to abandoning all forms of cutting. The school has a 'policy' that no staff member should promote the pharaonic cut to parents or students, which has been agreed by the staff and is well understood. Staff have participated in awareness raising sessions, however, they are not yet in a position where they can extend this policy to not promoting the sunna2.
The key features of the approach to cutting by Muse Ma'alesh Primary School include:

- a cross-school policy which is agreed by all staff (even though this is limited to not promoting the pharaonic cut)

- awareness raising for teachers and opportunities for them to talk to each other about the cutting of their female students

- collective responsibility across the school among male and female teachers that FGC is something they should all engage with and provide support for the girls

- active consultation with parents (actually listening to parents as well as providing information)

- involvement of local CSOs/NGOs

- a school nurse available to girls

- sessions where boys have an opportunity to learn about and discuss FGC

- a combination of (a) persuading girls not to undergo the pharaonic cut and (b) to actively support girls to manage their own complications after being cut.

\section{Conclusion}

Teachers' opinions on the abandonment of FGC are broadly in line with those of the communities in which they work. There is a discrepancy between what teachers feel is the role of schools in relation to $\mathrm{FGC}$ and the percentage of teachers taking action. The majority (84\%) of teachers feel that schools have a role to play in relation to FGC. However, only $42 \%$ have actually talked about it in schools. Teachers in schools in cities are less likely to talk about cutting, with only $33 \%$ doing so, than those in semi-city or village communities (55\%). Male teachers are more likely to see their role as raising awareness among parents, whereas female teachers place a higher emphasis on providing opportunities for girls to learn about cutting.

$43 \%$ of female teachers and $17 \%$ of male teachers have been asked for advice about FGC. The most common given advice is on (a) managing the effects of being cut, (b) telling girls not all are cut and suggesting that they can therefore resist being cut and (c) offering to talk to parents about the dangers of cutting their daughters.

A quarter of teachers take some kind of action in relation to FGC prior to the long school holidays when girls are likely to be cut. The main activities are talking to parents and girls, although the girls are unlikely to have the agency to prevent themselves being cut, given the age at which most are cut.

There is evidence that the education authorities recognise that teachers need some capacity building before they can play a strong role in the movement towards abandonment. Currently it is likely that teachers are giving very different messages based on their own widely differing beliefs about the cutting of girls.

One school provided an example of a whole school approach. The policy adopted permits the promotion of the sunna and the intermediate cuts but prohibits the promotion of the pharaonic cut. The support provided combines preventative measures with girls and parents as well as providing advice and guidance on managing the complications (i.e. promoting health seeking behaviour among survivors). 


\section{Key Themes}

The research findings confirm that the overall prevalence rate of FGC in Somaliland remains high at $98.9 \%$ in line with other recent studies (MICS 2006 \& 2011, EAUH 2009 \& 2016, Crawford and Ali 2015, NAFIS 2016 and Newell-Jones 2016). The prevalence rate is consistent across the age ranges, including among young women (15-24 years), whether girls attended school and whether they come from city, semicity or village communities.

These results indicate that FGC continues to be practiced almost universally among girls and women in Somaliland.

The SOFHA team identified the following themes arising from the research which are relevant to the national debate around FGC and the SOFHA project implementation.

\subsection{Change is happening and hoped for by over $90 \%$ of community members}

There is evidence of change in the type of cut being used in Somaliland with a decrease in the use of the pharaonic cut and an increase in the intermediate and sunna types. Approximately a third of young women (aged 15-24 years) underwent the pharaonic, intermediate and sunna cuts as opposed to almost $90 \%$ of women aged over 25 years. This change is most prominent among young women who have attended school.

The research suggests that change in type of cut in Somaliland is through a stepwise process (pharaonic $\rightarrow$ intermediate $\rightarrow$ sunna). There is no evidence currently of an increase in the proportion of girls who remain completely uncut.

The change in type is reflected in people's attitudes towards abandonment. Only $5 \%$ of those interviewed wanted to see the abandonment of all types of cutting in their communities, however, over $90 \%$ of people surveyed wanted to see some kind of abandonment, albeit mainly only the abandonment of the pharaonic cut $(73 \%)$.

Men appeared to be more open to change than women, with $89 \%$ of them wanting to abandon the pharaonic cut. This finding is in line with 'Population Council's 2016 report A State-of-the-art synthesis on female genital mutilation/cutting: What do we know now $?^{\prime 8}$ which indicates that in Eritrea, Guinea, Niger, Senegal, Sierra Leone and Sudan a smaller proportion of men than women support the continuation of FGC. The Somaliland data in this study also suggests that female teachers and health workers also seem to be more conservative about abandonment than their male counterparts. Overall, the findings suggest that men might be more open to change than is often portrayed, making their involvement in dialogue and decision-making an essential element in bringing about change.

Social norms theory suggests that individuals are more likely to change their behaviour if they think that the community as a whole is changing, as this means they need to change to comply with the changing social norms. Bicchieri ${ }^{9}$ (2013) uses the term 'pluralistic ignorance' to describe the state where some, or many, individuals incorrectly assume that others in their social group support a particular social norm. She stresses the need for transparent communication and open dialogue, which is not

8. Shell-Duncan B, Naik R and Feldman-Jacobs C (2016) A State-of-the-Art synthesis on female genital mutilation/cutting: What do we know now. Population Council http://www.popcouncil.org/uploads/pdfs/SOTA_Synthesis_2016_FINAL.pdf

9. Bicchieri C (2016) Norms in the wild: how to diagnose, measure and change social norms. Cambridge University Press currently taking place in Somaliland in relation to FGC. There is evidence from this research and Newell-Jones (2016) that men and women in Somaliland do not tend to talk about how each feel in relation to $\mathrm{FGC}$ and that the assumptions they make are not necessarily correct. In this study, for example, it is clear that men are more open to change than women perceive them to be.

If a mother is concerned that her daughter will not be able to marry unless she is cut and sewn with stitches as 'proof' of virginity, then knowing that there are young men who would prefer to marry an uncut girl and that some in her community would prefer to stop cutting altogether, might help her with her decision-making dilemma about her daughter. It may be possible therefore, to use the evidence that $90 \%$ would like to see change of some sort as a trigger for positive dialogue among different stakeholder groups. In this way, communities could be encouraged to be bold and to be a community which does not just follow, but leads, substantial change towards complete abandonment of all types of cutting.

\subsection{Increased medicalisation of cutting}

Strong evidence was found of an increase in the medicalisation of cutting, which is in line with the findings from the ActionAid research (Newell-Jones 2016) and also evident in a range of other countries, including Egypt, Sudan and Djibouti, that practice FGC (Population Council State-of-the-Art report, Shell-Duncan et al.). Although the majority of girls and women (92\%) are currently being cut by traditional cutters and TBAs, young women (15-24 years) are twice as likely to have been cut by a health professional $(11 \%)$ as women over 25 years old. The rate of change appears to be increasing as the daughters of women interviewed are more than twice as likely to have been cut by a health professional as their mothers ( $16 \%$ as opposed to $8 \%$ ). These changes are more prominent among young women who have attended school and those from city or semi-city communities where there are more health facilities.

Further evidence of medicalisation comes from the focus group discussions and key informant interviews. Community members, including a school principal openly and proudly report that they intend to have their daughters cut by a health professional. Health professionals interviewed in community hospitals and $\mathrm{MCH}$ centres also explain that they perform cutting of young girls, although they all report trying to persuade the mother not to use the most severe forms of cutting.

The current trend in medicalisation suggests that cutting is increasingly going to be carried out by health workers. This is likely to result in decreased income for traditional cutters who perform cutting. However, approaches which focus exclusively 
on finding alternative sources of income for traditional cutters are unlikely to bring about a reduction in the actual prevalence, as cutting is driven more by expectation and demand than the supply of cutters. Reducing the number of traditional cutters could lead to a further increase in the medicalisation of cutting. Strategies need to be developed which tackle the move towards medicalisation, which take into account the pressures on health professionals, highlighted in the case of the midwife (section 3.1), and address both the demands placed on health professionals and their motivations to perform the cut.

\subsection{Knowledge and awareness among communities is higher than anticipated}

This research suggests that the level of awareness among community members about FGC is higher than anticipated. Virtually all of those interviewed (96\%) knew that there were different types of cut used in their communities. Men were less familiar with the intermediate cut, although younger men were much more informed with a third of them knowing about the intermediate cut.

There is a substantial difference in the perceptions of the harm of cutting with and without stitches. $80 \%$ of women and $68 \%$ of men consider there to be no harmful effects of the sunna, but only $6 \%$ of women and $3 \%$ of men consider there to be no harmful effects of cutting with stitches. This suggests that an approach based on potential medical complications might be successful in reducing the prevalence of cutting with stitches (pharaonic and intermediate) but not in reducing the use of the sunna.

The vast majority of women (94\%) and men (97\%) were able to list complications resulting from cutting with stitches. The complications most commonly listed were problems with menstruation, severe pain, difficulties passing urine, problems in childbirth, infections and marriage difficulties. Health professionals were able to explain these using medical terms, however, community women and men were also aware of them and able to describe them using everyday language. There were some differences in the types of complications which men and women identified, with men being more likely to identify marriage problems and women more likely to talk about problems with menstruation, severe pain and difficulties passing urine. However, the key point is that people from both genders, all ages, all backgrounds and city, semi-city and village communities were all aware of a range of complications and able to describe many of these.

These findings suggest that decisions about cutting are being made despite people knowing about the types of cut and many of the complications i.e. lack of knowledge is unlikely to be the primary reason for continued cutting in most instances.

With the current level of knowledge about FGC, time spent telling people about the complications is unlikely to change attitudes. Approaches which provide opportunities for people to share their existing knowledge about types of cut, complications and the option faced by decision-makers in relation to FGC is more likely to result in people making decisions to change.

\subsection{Opportunities to exchange experiences and opinions about female genital cutting are limited}

Most information comes from the media (radio, TV, social media), NGOs/CSOs, health workers and public meetings, with little sharing of messages about cutting taking place in either the schools or families.

Although $72 \%$ of people have heard messages about FGC, few people have had opportunities to actually exchange experience and opinions. Where sessions are taking place in schools they tend to be providing information on the complications of cutting and trying to persuade parents not to use the most severe forms of cut or to persuade girls that they do not need to be cut. Equally, those who have attended community meetings or workshops say the focus was on providing information to them, rather than enabling them to discuss their intentions or the challenges they faced in relation to their daughters with each other. In most of these situations community members are passive participants, primarily expected to listen to 'facts' presented by 'experts'.

The focus group discussions have provided several examples of how people change their minds as they exchange experiences and opinions with others. There were occasions where young men became aware of the contradiction between wanting girls not to be harmed and wanting proof of virginity; where women realised that they differed on their interpretation of the opinions of religious leaders; and where young women recognised that more of their peers felt like they did about FGC than they thought.

Interventions to date have tended to focus on providing information to community members, assuming they know little and also assuming that the provision of information itself will result in a change in behaviour. Whilst recognising that accurate information is important, this research suggests increasing the opportunities for genuine dialogue is more likely to bring about changes in behaviour.

\subsection{People face decision-making dilemmas about female genital cutting}

A key finding, which is not widely discussed, is that decisionmaking in relation to $\mathrm{FGC}$ is not straightforward but involves complex decision-making dilemmas. Parents are balancing conforming with the social expectations to verify their daughters' purity and virginity by cutting, with wanting their daughters not to suffer from complications as a result of being cut. Mothers, the key decision-makers, are balancing wanting not to harm their daughters with their perceived expectations of religious leaders, the father and the wider community. Midwives and other health professionals are faced with the contradiction between their personal preference, their understanding of their professional role and the pressure they feel under to minimise the harm done to an individual girl. Teachers are faced with balancing their personal opinions on cutting, their understanding of the role of their school and their personal role as a teacher or principal. 
These decision-making dilemmas arose frequently in focus group discussions and key informant interviews and were also implied in the survey data. There was, for example, a difference in the intentions of all mothers and those who have uncut daughters in grades $1-3.17 \%$ of all mothers said they intended leaving their future daughters uncut (chart 38), however, none of the mothers who have uncut daughters in grades 1-3 intended to leave their daughters uncut. In discussion groups, mothers who were in the process of making these difficult decisions (i.e. had uncut daughters in grades 1-3) were cautious about breaking the social norms, whereas others felt more able to say that they hoped that community attitudes will have changed by the time they are making these decisions and so felt more comfortable saying they intended to leave them uncut. So, there is a difference between the opinions of the women when talking about the cutting of daughters in general and that when it relates to a decision they are currently making.

Decision-making dilemmas relating to $\mathrm{FGC}$ have also been identified in Somaliland in other recent research (Crawford \& Ali 2015 and Newell-Jones 2016) and are experienced across most, if not all, stakeholder groups and in other countries. If changing attitudes in relation to FGC are perceived as less to do with following on from having accurate knowledge and more to do with making difficult decisions this will have implications for the kinds of activities and interactions which are most likely to successfully bring about change.

\subsection{Schools require support to become environments for change}

SOFHA has a specific interest in the role of schools in bringing about change in relation to $\mathrm{FGC}$ based on the strong role which schools have played in countries where the prevalence of FGC has been reduced substantially.

In Somaliland, most government schools have not developed whole school approaches to FGC. The support offered to girls and their parents is limited and often based on the personal efforts of individual teachers.

The majority (84\%) of teachers felt that schools had a role to play in relation to FGC. Male teachers are more likely to describe the school's role as talking to parents, whereas female teachers are more likely to see it as providing opportunities for girls to learn about the potential complications of cutting. However, only half as many teachers (42\%) had actually spoken about FGC at school, suggesting that many felt the school had a role to play, but that they did not necessarily consider it to be their responsibility.

Teachers' experiences and opinions in relation to FGC are broadly in line with those of the communities in which they work. Only $2 \%$ of teachers want to see the abandonment of all types of cutting. Without substantial support to change their own attitudes towards the cutting of girls and women, teachers are unlikely to be equipped to be effective agents of change.

There is some confusion and contradiction about the most appropriate time and way in which schools can influence attitudes in relation to FGC. Girls tend to be cut in primary grades 3-5, whereas sessions for girls on health and hygiene tend to be given to girls older than this on the basis that younger girls will not understand. Both primary and secondary school staff said that FGC should not be discussed in their schools. Secondary school staff felt that as the girls are cut when at primary school, it was not therefore necessary to talk to them at secondary school. Whereas, primary school staff felt that the girls would only be able to understand fully about FGC when in secondary school. The Regional Education Officer in Berbera sums up the situation as follows;

"Most of our teachers have had no training at all on FGM and so are not ready to play a role. However, I think FGM should be part of the teaching training curriculum".

One school visited had introduced a policy on FGC and had a series of measures in place to promote dialogue and exchange both in relation to reducing the severity of the cut being used and also promoting health seeking behaviour. Male and female staff, parents and students were encouraged to be involved in discussions about FGC. A local CSO, with a commitment to the abandonment of all types of cutting, was invited to provide training for staff and the school actually consulted with parents as well as providing information to them.

The findings from this research, combined with the practice of schools where the prevalence of FGC has reduced substantially, could form the basis for drawing up good practice guidelines and policies on FGC for schools, as well as teacher training, in the future.

\subsection{Youth (female and male) are an untapped resource for change}

The findings of this research indicated that young people (aged 15-24 years) are more informed than older people and also are keen to become more involved in activities to reduce FGC.

The change in the type of cut among young women means that they are the first generation where a substantial proportion of them have undergone a cut less severe than their mothers. This represents a significant change in attitudes, which if brought more into public debate, could influence further change. The majority of young women said they would like to intervene to prevent younger girls from undergoing the most severe forms of cutting.

Young men are more informed than older men about the three different types of cut being used in Somaliland and consequently more able to engage in meaningful discussion with their future wives about the cutting of their future daughters or the requirements of their future daughters-in-law. The overwhelming majority $(89 \%)$ of young men said they would prefer to marry a young woman who had only undergone the sunna type of cut, with $84 \%$ of them saying this was a significant factor in their selection of a future wife. Additionally, although only $3 \%$ of young men prefer to marry a girl who is uncut, $29 \%$ said they would prefer their own daughters not to be cut at all. This suggests that involving men more in discussions about the cutting of young girls would increase the pressure to move away from the pharaonic and intermediate cuts and would be likely to promote the case for a complete abandonment of all types of cutting.

The majority of young women (75\%) and young men (87\%) would like to be involved in activities to reduce cutting in the future, with only half of these currently being involved. The most common barriers were (a) not knowing what to do to support change in relation to $F G C$, (b) fear of being ridiculed and (c) not understanding enough about FGC. 


\subsection{Promoting health seeking behaviour receives limited attention}

The United Nations Population Fund (UNFPA) are in the process of developing a common approach to FGC based on a commitment to Zero Tolerance with an overall goal to reduce FGM/C prevalence by $40 \%$ in 5 years. The Ministry of Labour and Social Affairs (MoLSA) in Somaliland and UNFPA have led the process of developing National Indicators on FGC, with capacity building support from Population Council. This process will feed into the development of regional and global indicators. The UNFPA framework has three components: Policy Framework, Community Engagement and Service Provision. Organisations involved in the work to promote the abandonment of FGC are encouraged to include activities which address these three components. Service delivery includes improving the availability and quality of clinical support services in relation to FGC, as well as promoting positive health seeking behaviour among girls and women.

Currently less than $5 \%$ of women and girls suffering complications as a result of being cut actually seek support from health facilities. Instead they approach family members for advice on how to manage their complications, particularly their mother or grandmother. Consequently, girls and women are likely to be suffering more severely from medical complications arising from being cut than if they had sought support and advice from health professionals.
This raises questions of both supply of, and demand for, clinical support.

Even in cities and semi-cities, where there are more health facilities than in villages, only $5 \%$ of girls and women seek support from health facilities, suggesting that the social norm is to seek support from within the family only and that health seeking behaviour needs to be actively developed. There have been successful campaigns to promote accessing health facilities during pregnancy, childbirth and post-natal care for mothers and infants, however, this has not yet been extended to seeking support for cutting related complications including different options for young women being re-opened before marriage.

Where schools are active in relation to FGC, the focus tends to be on providing information about the complications of cutting in order to persuade families not to use the most severe forms of cutting. School nurses are not provided by the Somaliland Government. Most girls and young women are not able to seek advice at school about health issues or concerns from a nurse and consequently do not develop positive health seeking behaviours. Where a school nurse is available, there tends to be a stronger focus on managing complications arising from being cut.

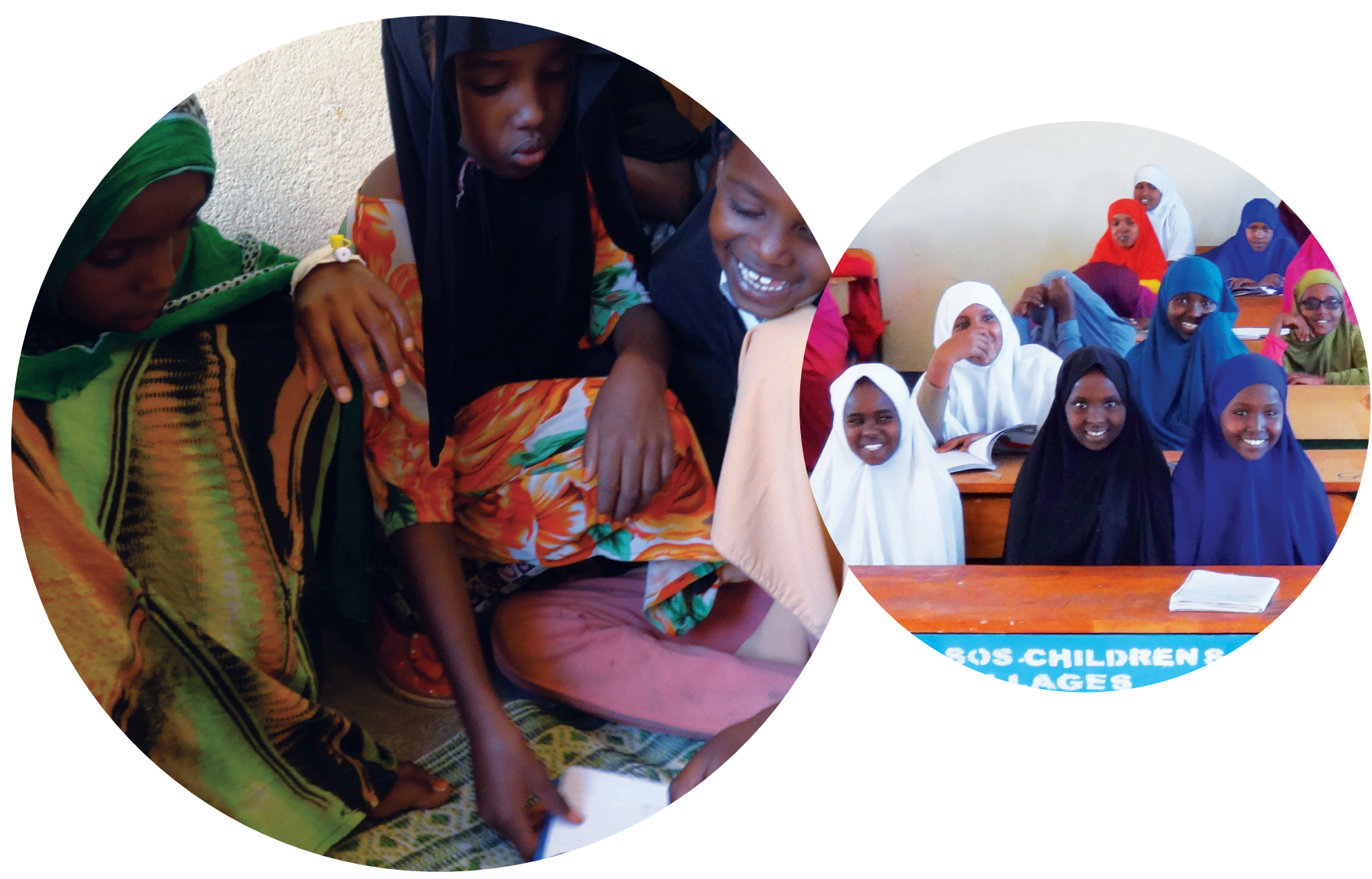




\section{Implications for the project}

\subsection{Selecting and supporting change agents}

Community members acting as change agents are key to maximising the impact of the interventions and to promoting sustainable change. In order to be effective, change agents need to have attitudes which reflect the goal of the project, rather than the current situation within the community.

SOFHA is committed to the complete abandonment of all types of cutting. This research suggests that it will be difficult to find sufficient numbers of change agents who are committed to the abandonment of all types of cutting in schools, health facilities and mosques within the lifetime of this particular project. Teachers and health professionals in Somaliland hold a wide range of opinions in relation to FGC and therefore SOFHA will need to consider carefully the selection of change agents from among these groups, their initial training and on-going support.

SOFHA are using young people as volunteer facilitators in schools. The research suggests that young people have many of the attitudes required to be effective change agents and that there could be advantages to using them in a wider variety of roles throughout the project, for example, in advocacy roles communicating with policy makers as well as in awareness raising sessions for health professionals and teachers.

\subsection{Approaches to 'sessions'}

Currently, most SOFHA workshops focus primarily on providing information on the types of cut and the potential health complications. The assumptions are that people do not know of the complications and that once they do know they will change their minds and abandon cutting.

The research suggests that the level of knowledge about cutting and the potential health risks is higher than anticipated and that many people are involved in complex decision-making dilemmas in relation to FGC.

Providing opportunities for young women and young men, parents, health workers, teachers and others to exchange opinions and discuss the dilemmas they face would seem to be a more effective approach when planning sessions with stakeholders. This would require revising the timing as well as the content of the sessions in order to allow time for these discussions to take place. Facilitators will also need to adopt a different approach to the sessions; one of facilitating discussion and encouraging listening to different perspectives, rather than just providing information. Drama, theatre and role play could be valuable approaches to help participants explore different options.

\subsection{Promoting health seeking behaviour}

Many of the groups which SOFHA convenes on FGC include girls (or parents of girls) who have been cut as well as those who have not been cut. Currently the primary focus of the sessions is on reducing the likelihood of the uncut girls being cut. Less emphasis is placed on promoting health seeking behaviour among those who are suffering from complications arising from being cut. This includes minimising and managing short term health complications resulting from being cut, being aware of the different options for young women who have undergone the intermediate or pharaonic cuts prior to being married, identifying and seeking medical support for long term complications of being cut. This is one of the three themes in the national indicators being developed on FGC which are being promoted and supported by Population Council, UNFPA and the Ministry of Labour and Social Affairs (MoLSA), with funding from Norad.

The impact of the SOFHA project might be enhanced by an increased focus on promoting health seeking behaviour. This could substantially reduce the severity of the health complications suffered by young girls and women, as well as provide further pressure in the change away from the pharaonic and intermediate cuts, in particular.

Additionally, if more health professionals were involved in providing advice to girls and women on the health complications, this might assist them in opposing the medicalisation of cutting.

\subsection{Supporting schools}

Schools are a core element of the SOFHA project with sessions being offered to large numbers of teachers, parents and students. Key staff from each school are participating in workshops the aim of which is to develop strategies to implement in their schools on FGC. These sessions could be used to introduce the good practices identified in section 3.7 including:

- developing a cross-school policy which is agreed by all staff which combines measures to reduce the prevalence of cutting of students and also provides supports for those girls who have undergone the cut

- training for teachers and opportunities for them to talk to each other about the cutting of their female students

- developing collective responsibility across the school among male and female teachers that FGC is something they should all engage with and provide support

- active consultation with parents (actually listening to parents as well as providing information)

- linking with local CSOs/NGOs working on FGC

- providing sessions where girls and boys have an opportunity to learn about and discuss FGC

- promoting positive health seeking behaviour among girls and their parents in relation to FGC.

\subsection{Training manuals and handbooks}

Currently, training manuals and handbooks focus primarily on providing information on types of cut and health risks of cutting. The findings from this research suggest that the following might enhance these resources:

- activities to promote the exchange of experiences and discussions on the decisions people face in relation to FGC

- including activities which promote health seeking behaviour among girls and women who have been cut.

A move towards creating forums for discussion rather than providing information in mini-lectures also requires a change in the type of training required for facilitators. 


\section{Recommendations for monitoring, evaluation and learning}

The figures in the table below are selected from the baseline research as indicative of the current situation in relation to FGC and against which progress could be measured. Some, for example overall prevalence, is unlikely to change within the lifetime of the project. Others, for example the percentage of young women seeking support from clinical services, could increase substantially following intervention.

\begin{tabular}{|c|c|c|}
\hline PMP no. & $\begin{array}{l}\text { Project management } \\
\text { plan (PMP) indicator } \\
\text { and section in report }\end{array}$ & Evidence from baseline research and comments \\
\hline Goal 1 & $\begin{array}{l}\text { Prevalence of FGC } \\
\text { amongst women and } \\
\text { girls in Somaliland } \\
\text { (disaggregated by } \\
\text { age, type of cut, } \\
\text { education, rural/ } \\
\text { urban, type of } \\
\text { cutter) } \\
\text { Section } 3.1\end{array}$ & 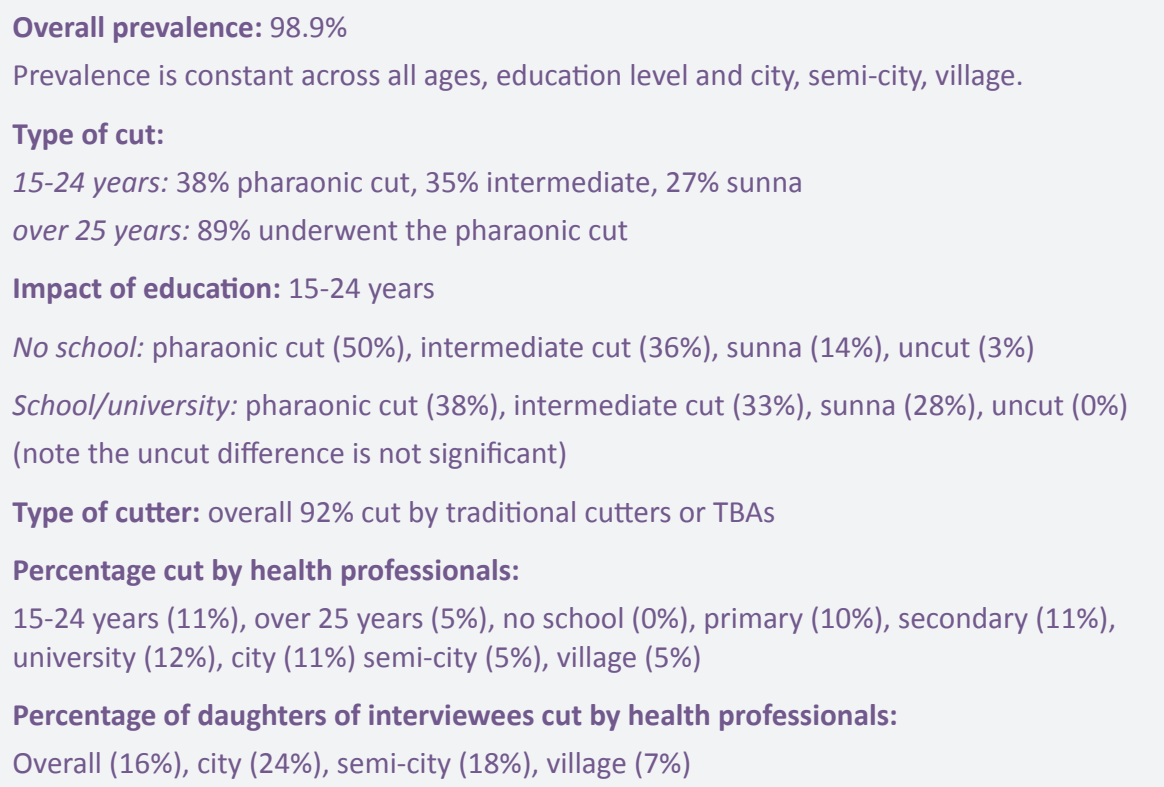 \\
\hline Objective 2a & $\begin{array}{l}\text { Percentage } \\
\text { of population } \\
\text { supporting } \\
\text { abandonment of } \\
\text { FGC (disaggregated } \\
\text { by gender, age, } \\
\text { beneficiary type) } \\
\text { Percentage } \\
\text { of population } \\
\text { NOT supporting } \\
\text { alternative FGC } \\
\text { (disaggregated } \\
\text { by gender, age, } \\
\text { stakeholder group } \\
\text { and type of FGC } \\
\text { practice) } \\
\text { Section } 3.5\end{array}$ & 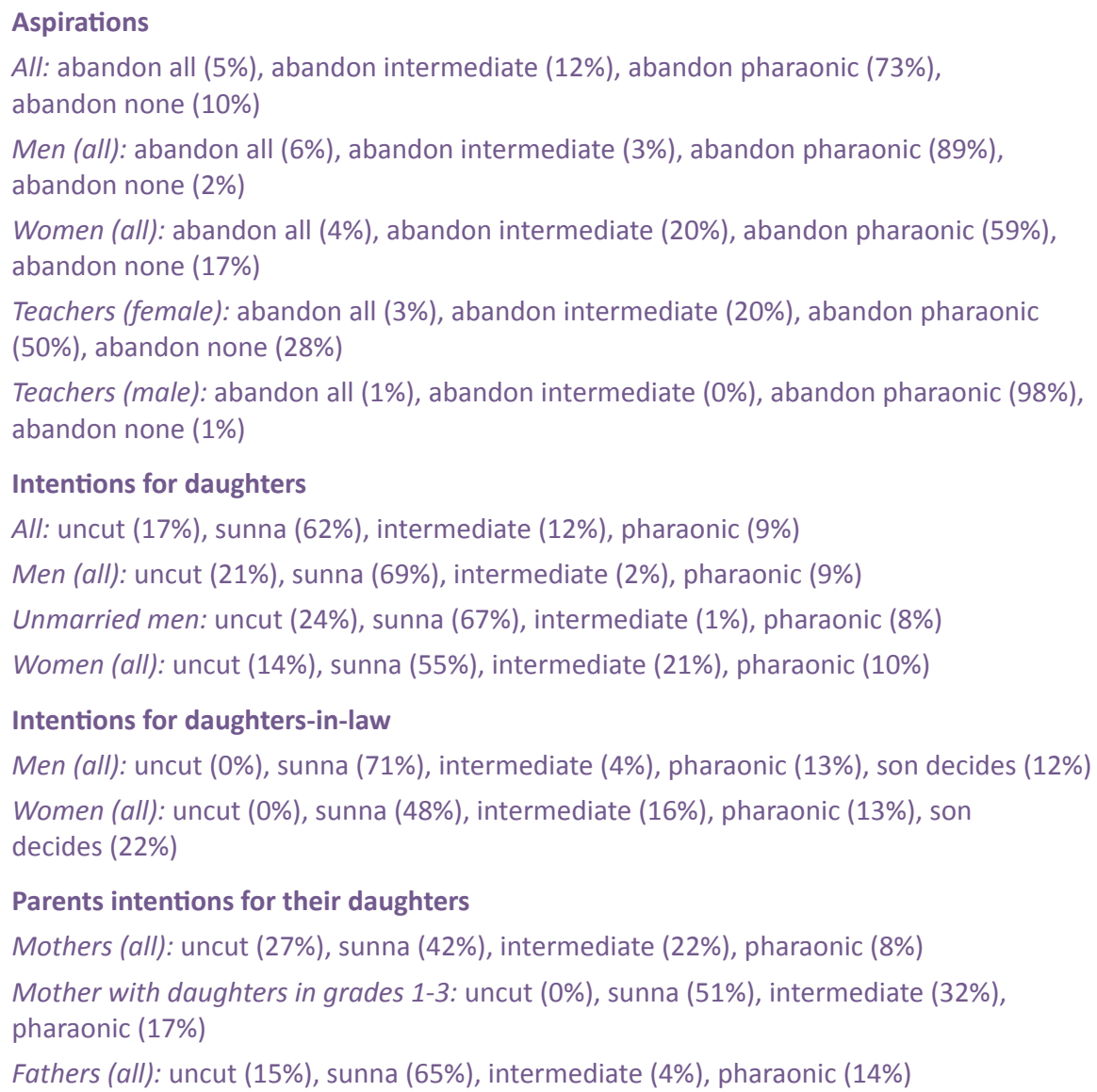 \\
\hline
\end{tabular}


Fathers with daughters in grades 1-3: uncut (8\%), sunna (78\%), intermediate (3\%), pharaonic (11\%)

\section{Qualitative data}

SOFHA could select a sample of different stakeholders and interview them after they have been involved in project activities asking them:

- What do they feel about the abandonment of FGC?

- How, if at all, they have changed their attitude as a result of being involved in the SOFHA programme?

- What actions, if any, have they taken as a result of their change of attitude?

- What do they think would need to happen for them to support the abandonment of all types of cutting, if they do not support it already?

A selection of these could be written up as brief case studies demonstrating the kinds of changes which have been triggered as a result of being involved in the programme.

\section{Objective 2b Percentage of people who know the effects of FGC (disaggregated by gender, age, stakeholder group)}

Section 3.3

\section{Knowledge of types of cut}

Overall $96 \%$ of people interviewed knew there were different types of cut

By age

Women (all): sunna (94\%), intermediate (55\%), pharaonic $(69 \%)$

Young women (15-24 years): sunna (94\%), intermediate (50\%), pharaonic (66\%)

Men (all): sunna (66\%), intermediate (8\%), pharaonic (80\%)

Young men (15-24 years): sunna (51\%), intermediate (36\%), pharaonic (77\%)

\section{By community type}

Young men (city): sunna (72\%), intermediate (35\%), pharaonic (48\%)

Young men (semi-city): sunna (66\%), intermediate (48\%), pharaonic (34\%)

Young men (village): sunna (65\%), intermediate (13\%), pharaonic (57\%)

\section{Knowledge of complications}

Percentage considering girls and women suffer NO harmful effects of the sunna (no stiches): women (80\%), men (68\%)

Knowledge of types of complications from cutting WITH stitches (no significant differences by age, community type or role)

None: women (6\%), men (3\%)

Problems with menstruation: women (62\%), men (33\%)

Severe pain: women (41\%), men (22\%)

Difficulties passing urine: women (45\%), men (23\%)

Problems in childbirth: women (30\%), men (39\%)

Infection/fever: women (29\%), men (14\%)

Severe bleeding: women (26\%), men (20\%)

Difficulties with marriage: women (15\%), men (25\%)

Swelling: women (5\%), men (1\%)

Problems conceiving: women (5\%), men (3\%)

Infertility: women (1\%), men (3\%) *

Fistula: women (2\%), men (3\%) *

Psychological trauma/shock: women (6\%), men (3\%)

* Further research is required on the links between $\mathrm{FGC}$ and infertility or fistula.

\section{Qualitative data}

The project includes workshops and forums for a large number of different stakeholder groups including teachers, parents, health workers, young men, young women which will include information on the types of cut and complications. Participants could be invited to identify (a) what they have learned and (b) what they are going to do as a result. The SOFHA team could select a sample of the participants to interview 6 months afterwards to find out what actions, if any, they have carried out and with what result. 
Percentage of people who report to have heard anti-FGC messages (disaggregated by gender, age, source of message)

Section 3.4

\section{Objective 4a}

Percentage of women and girls affected by FGC who have received FGC related clinical and support services (disaggregated by age and type of service)

Section 3.2
Overall: $72 \%$ of people interviewed have heard messages about FGC Men $(80 \%)$, women $(65 \%)$

In cities $(77 \%)$, in semi-cities $(74 \%)$, in villages (63\%)

\section{Source of messages (female/male)}

Radio (40\%/61\%), NGOs/CSOs (28\%/19\%), health workers (20\%/10\%), schools (7\%/3\%), families $(3 \% / 2 \%)$, TV $(22 \% / 15 \%)$, posters $(3 \% / 3 \%)$, Mosques $(5 \% / 5 \%)$, public meetings $(13 \% / 13 \%)$

\section{Qualitative data}

Gathering a collection of information on the types of messages which members of the community are hearing. This could involve:

- collecting examples or taking photographs of leaflets, posters and other written materials

- listening to different radio and TV messages

- participating in public meetings and activities at the Mosques when FGC is being mentioned

- participating in any workshops, school meetings etc. where FGC is being covered.

The team should note the nature of the messages being given, in order to be able to categorise them and analyse them. The results can be used to improve the quantitative data gathered on the messages being given on FGC. Participants can also be asked which messages they feel have the greatest impact, and why.

Overall: $<5 \%$ seek help from health professionals (aged 15-24)

Percentage of women who were cut who suffered complications and sought support 15-24 years: cut (99\%), complications (43\%), sought support from health professionals (4\%)

$25-40$ years: cut (99\%), complications (70\%), sought support from health professionals (4\%)

Over 40 years: cut $(98 \%)$, complications ( $84 \%)$, sought support from health professionals (1\%)

These figures were not disaggregated by type of service ( $\mathrm{MCH}$, pharmacy, hospital) as the numbers were so small that differences would not be significant.

At mid-term and end of project it might be possible to measure:

- the number of women seeking support from SOFHA clinics for complications

- the number of schools providing clinical support for complications

\section{Qualitative data}

The baseline has established where women go when they need support, however further exploration is necessary to know how to increase the percentage accessing health facilities.

It would be useful to consider the perspective of both the young women and the health professionals. This could be done through:

(a) focus group discussions with young women (15-24 years) exploring:

- How would they go about seeking help from a health professional?

- What kinds of symptoms would result in them seeking support of a health professional?

- What response have any young women had when they have approached a health professional?

- Are there any barriers to a young girl visiting an $\mathrm{MCH}$ or hospital?

- Would they be able to go on their own or would they need to be accompanied by their mother or an older female relative?

- What are the costs of medication and treatment? Who would pay?

(b) interviews with a selection of health professionals exploring:

- What types of issues/complications relating to undergoing FGC do women present with?

- What kind of support they are able to give? What are the costs?

- What training have they had to provide this support?

- What, if any, suggestions do they have for improving the service they can provide? 


\section{Conclusions}

This research confirms the current prevalence rates and provides baseline data for SOFHA's current intervention on FGC against which progress can be measured.

Change is happening in relation to FGC in Somaliland in terms of the type of cut and the person who is cutting. There is evidence of a move from the pharaonic to the intermediate and sunna cuts. However, the overall prevalence rate remains high at $98.9 \%$ for all age ranges.

The change in the type of cut presents SOFHA with a significant challenge of how to maximise the rate of change, yet also maintain the goal of complete abandonment of all types of cut. Over $90 \%$ of community members would like to see the pharaonic cut abandoned, yet less than $4 \%$ of support the abandonment of the sunna cut. Focusing on supporting the abandonment of the pharaonic and the intermediate cuts might result in the greatest reduction in physical harm to girls and women over the lifetime of the project, however, it also risks of being seen as condoning the sunna cut.

SOFHA is well-placed to contribute to opposing the medicalisation of cutting, which is confirmed in this report, as they work closely with the Edna Adan University Hospital (EAUH) and facilitate sessions on midwifery training courses as part of this project. The evidence from this research, highlighting the decision-making dilemmas faced by health professionals could support the development of new approaches to training health professionals on FGC.

SOFHA are committed to working through schools to promote the abandonment of FGC. This research provides insight into the attitudes of teachers, the need for training and also to the possibility of developing whole school approaches on FGC.

This research provides insight into the knowledge, attitudes and behaviours of young people (15-24 years) which can support SOFHA and other organisations in involving young people as change agents in relation to FGC.

Perhaps most importantly, a key finding of this research is that community members, male and female, young and old, know more about FGC than is often thought, yet they still decide to cut their daughters. People from different backgrounds talk about the decision-making dilemmas they face, rather than the knowledge they lack about FGC. They also talk about not having opportunities to engage with each other in discussion about the difficult decisions they face. They describe how in most workshops, community meetings and awareness raising sessions, they are expected to be passive listeners, rather than active participants discussing the challenges. When offered opportunities to exchange experiences in focus group discussions, many began to change their opinions. This finding has significant implications for how sessions with the full range of stakeholders are facilitated and suggests that a more interactive and participatory approach would increase the likelihood of attitudinal and behaviour change in relation to FGC.

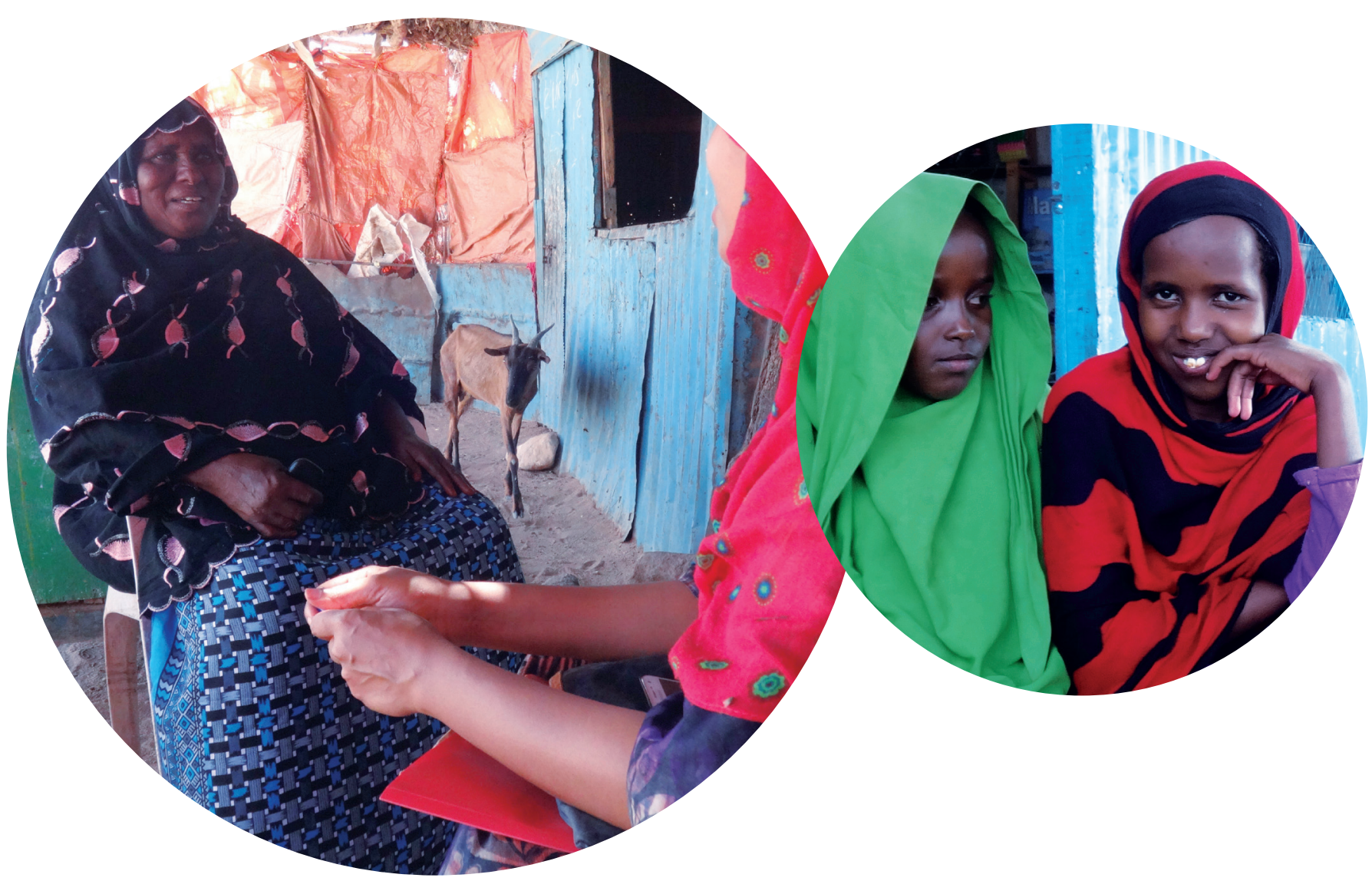




\section{Appendix A: Terms of Reference}

\author{
Terms of Reference for FGM/C baseline survey \\ among school girls
}

Introduction

SOFHA is currently implementing a 3 year Norad funded female genital mutilation/cutting (FGM/C) project in Somaliland, which seeks to empower a first generation of Somalis to abandon $\mathrm{FGM} / \mathrm{C}$. The project is designed to accelerate interventions towards the abandonment of FGM/C practiced in Somaliland by developing a 5-year strategy toward the eradication of FGM/C in Somaliland. This will be done by targeting Sheikhs/religious leaders and the Ministry of Religious Affairs (MoRA) in order gain their support and to produce a statement so that individuals can choose to abandon FGM/C. Other groups targeted with various interventions include: students, nurses, government workers, media persons, youths, teachers, and parents. These groups are targeted in the 6 major cities of Somaliland by reaching them in schools, universities, $\mathrm{MCH}$ clinics, youth clubs and general community. This project consists of both clinical and community aspects that have been integrated into the other existing project work that SOFHA implements.

The objectives of this project include:

a. To strategise a FGM/C campaign in Somaliland

b. To increase the public commitment for the eradication of $\mathrm{FGM} / \mathrm{C}$

c. To promote the criminalisation of medicalisation of $\mathrm{FGM} / \mathrm{C}$ in Somaliland

d. To reduce the health and social complications resulting from $\mathrm{FGM} / \mathrm{C}$ procedures

The project is implemented through a project Task Force including: SOFHA, MoRA, MOH, MoLSA, MOE that meet monthly throughout the life of the project. The role of the taskforce is to provide technical guidance to the project, advocate for project issues in other national forums and members as a link between SOFHA and their respective organisation. Note: $\mathrm{MOH}, \mathrm{MoRA}$, MOE \& MoLSA are the government Ministries of Health, Religious Affairs, Education and Labour and Social Affairs.

Note: MOH, MORA, MOE \& MoLSA are the government Ministries of Health, Religious Affairs, Education and Labour and Social Affairs.

\section{Country situational analysis}

The assessment of prevalence, perception and attitudes of FGM/C in Somaliland (2014) carried out by the Network Against FGM in Somaliland (NAFIS) used a descriptive cross-sectional survey approach, supported by focus group discussions and key informant interviews and took place across all six regions of Somaliland. The prevalence rate of FGM/C was found to be $99.8 \%$ with $82.3 \%$ undergoing the pharaonic cut. The NAFIS report also investigated the decision-making process around FGM/C reporting that women, particularly mothers, are the principle decision makers with the fathers being involved in less than $20 \%$ of the households and taking responsibility for the decision less than $2 \%$ of the time.
The MICS surveys (2006 \& 2011) for Somalia and the EAUH surveys for Somaliland are alike in having spoken only to 'adult' women above 15 years old. The EAUH surveys interviewed women presenting at the maternity hospital in Hargeisa who come from throughout Somaliland, while the women surveyed in MICS came from across Somalia. Unlike various comparable DHS surveys in other practising countries, men surveyed in the MICS (2006 \& 2011) in Somalia were not asked about their knowledge and attitude towards FGM/C or their expectations for its continuation. Anecdotally it is known that Somali men have strong opinions about $\mathrm{FGM} / \mathrm{C}$, and this baseline survey represents an opportunity to gain some robust data about the attitudes of men in Maroodi Jeex and Togdheer. While there is 'daughter data' based upon questions asked to mothers in the MICS (2006 \& 2011) data, there is no existing data direct from girls themselves, about their FGM/C status and attitudes, or from boys about their knowledge and beliefs.

Baseline research objectives:

- To identify the prevalence of FGM/C among women and school aged girls (disaggregated by ages of cutting, rural/ urban, educational level of parents, type of school private/ government and including the type of access to clinical and support services)

- To understand the knowledge, attitude and practice regarding FGM/C among parents, adolescents and teachers (including their knowledge of cutting, which types they support and the messages they have heard about FGM/C)

- To investigate young men's future preferences and their role in interventions to end FGM/C (including marriage intentions for themselves and their sons in future, role in campaigning against cutting)

- To gather relevant baseline data for key project indicators to enable changes in beneficiaries' lives to be measured over the course of the project.

Users of the baseline data and information:

- The output of the survey will inform SOFHA along with the line ministries and other stakeholders to measure the impacts of the efforts of abandonment of FGM/C in the country

- SOFHA as a direct beneficiary of information will use it for tracking key project indicators and to support the FGM/C project focus and interventions.

Methods and targets

A community survey approach, supported by focus group discussions (FGDs) and key informant interviews (KIIs) will be used for the baseline research. Target groups will include women, men, secondary school students, university students, teachers, parents in public and private schools, health workers, government workers and religious leaders.

\section{Regions}

The research will be conducted primarily in 3 regions - Sanaag, Saahil and Awdal with supplementary data collection for school aged girls in Maroodi Jeex and Toghdeer. An earlier baseline research was conducted in Maroodi Jeex and Togdheer regions during January-May 2016 for an ActionAid 4-year project 'Empowering communities to collectively abandon FGM/C in Somaliland' and the majority of the data collected in the research was similar to SOFHA's needs with the exception of prevalence rates of FGM/C among school-aged girls. 


\section{Project indicators}

The baseline research should produce data on the following project indicators:

\begin{tabular}{|c|c|}
\hline $\begin{array}{l}\text { PMP } \\
\text { no. }\end{array}$ & Performance monitoring plan (PMP) indicator \\
\hline G1 & $\begin{array}{l}\text { Prevalence of FGM/C amongst women and } \\
\text { girls in Somaliland (disaggregated by age, type } \\
\text { of cut, type of school, rural/urban, education } \\
\text { level of parents) }\end{array}$ \\
\hline OB2a & $\begin{array}{l}\text { Percentage of population supporting } \\
\text { abandonment of FGM/C (disaggregated by } \\
\text { gender, age, beneficiary type - teachers, } \\
\text { government workers, nurses and students } \\
\text { etc.) }\end{array}$ \\
\hline OB2b & $\begin{array}{l}\text { Percentage of people who know the effects } \\
\text { of FGM/C (disaggregated by gender, age, } \\
\text { beneficiary type) }\end{array}$ \\
\hline OB2c & $\begin{array}{l}\text { Percentage of people who report to have } \\
\text { heard anti-FGM/C messages (disaggregated by } \\
\text { gender, age, source of message) }\end{array}$ \\
\hline OB2d & $\begin{array}{l}\text { Percentage of population NOT supporting } \\
\text { alternative FGM/C (disaggregated by gender, } \\
\text { age, beneficiary type and type of FGM/C } \\
\text { practice) }\end{array}$ \\
\hline OB4a & $\begin{array}{l}\text { Percentage of women and girls affected by } \\
\text { FGM/C who have received FGM/C related } \\
\text { clinical and support services (disaggregated by } \\
\text { age and type of service) }\end{array}$ \\
\hline OB4b & $\begin{array}{l}\text { Proportion of health workers with skills on } \\
\text { treating FGM/C complications }\end{array}$ \\
\hline
\end{tabular}

Research consultant: tasks and outputs

\section{Tasks}

Pre-first visit

Support discussion on the nature and focus of the baseline research with SOFHA and Population Council

Design the data collection tools

Approach ActionAid International Somaliland (AAIS), with SOFHA, to provide access to their web server for the uploading of the data (if AAIS are unwilling to provide this then another host will need to be sourced immediately)

Write the protocols and guidelines

Write draft implementation plan
Undertake first visit to Somaliland (2 weeks)

Support SOFHA on planning the data collection process finalising the implementation plan

Facilitate workshops with the SOFHA team on ethical research and community data collection ( 2 days)

Support SOFHA in piloting the data collection tools and reviewing the initial data

Revise the data collection tools following feedback from piloting

Undertake focus group discussions (FGDs) and key informant interviews (KIIs) with key stakeholders in selected communities

Visit MoLSA, MoRA as appropriate

Revise budget in the light of the first visit (some initial costs were estimates as indicated)

\section{Data analysis}

Analyse community data collected by SOFHA team Write up and identify key themes from FDGs and KIIS Produce summary of initial findings for review

Undertake second visit to Somaliland

Undertake FDGs and KIIs with key stakeholders, as appropriate

Facilitate dissemination seminar/workshop (not included in budget)

Final report

Produce draft report on findings and recommendations Revise report following feedback

Deliverables

Inception plan for baseline research (explaining methodology, sample procedure and size, logistics, quality assurance)

Data collection tools and protocols (for baseline and readily adaptable for annual monitoring)

- Questionnaires for use with mobile data devices

- Guidelines and record forms for consent

- Role description for community researchers

- Target numbers per community

Summary report on the capacity building training for SOFHA staff on:

- Ethical research/implementation of research

- Links between baseline research and on-going project $M \& E$

Database of baseline research clean and accessible for ongoing project monitoring

Report on the findings and recommendations of the baseline research including:

- Executive summary

- Context of FGM/C in Somaliland

- Methodology

- Research findings

- Key themes

- Implications for the project

- M\&E/Conclusions 


\section{Appendix B: SOFHA project performance monitoring plan}

\begin{tabular}{|c|c|c|c|c|c|c|c|c|c|}
\hline \multirow{2}{*}{$\begin{array}{l}\text { Indicator } \\
\text { No. }\end{array}$} & \multirow{2}{*}{$\begin{array}{l}\text { Project } \\
\text { Indicators }\end{array}$} & \multirow[t]{2}{*}{ Indicator definitions } & \multirow{2}{*}{$\begin{array}{l}\text { Baseline } \\
\text { (2016) }\end{array}$} & \multicolumn{3}{|c|}{ Targets } & \multirow[t]{2}{*}{ Data sources } & \multirow{2}{*}{$\begin{array}{l}\text { Frequency of } \\
\text { collection }\end{array}$} & \multirow[t]{2}{*}{ Responsible } \\
\hline & & & & $\begin{array}{l}\text { Year } \\
1\end{array}$ & $\begin{array}{l}\text { Year } \\
\mathbf{2}\end{array}$ & $\begin{array}{l}\text { Year } \\
\mathbf{3}\end{array}$ & & & \\
\hline
\end{tabular}

GOAL: Abandonment of FGM/C practice in Somaliland

\begin{tabular}{l|l|l|}
$\begin{array}{l}\text { Indicator } \\
\text { G1 }\end{array}$ & $\begin{array}{l}\text { Prevalence of } \\
\text { FGM/C amongst } \\
\text { women and girls } \\
\text { in Somaliland } \\
\text { (disaggregated } \\
\text { by age, type of } \\
\text { FGM/C) }\end{array}$ & $\begin{array}{l}\text { This refers to } \\
\text { proportion of } \\
\text { women and } \\
\text { girls who have } \\
\text { undergone any form } \\
\text { of FGM/C } \\
\text { Numerator: Number } \\
\text { of women who have } \\
\text { undergone FGM/C in } \\
\text { the surveyed areas } \\
\text { Denominator: Total } \\
\text { number of women } \\
\text { and girls surveyed }\end{array}$
\end{tabular}

OBJECTIVE 1: To strategise FGM/C campaign in Somaliland

\begin{tabular}{|c|c|c|c|c|c|c|c|}
\hline $\begin{array}{l}\text { Indicator } \\
\text { OB1a }\end{array}$ & $\begin{array}{l}5 \text { year } \mathrm{FGM} / \mathrm{C} \\
\text { strategy in place }\end{array}$ & $\begin{array}{l}\text { This indicator tracks } \\
\text { the progress of } \\
\text { FGM/C strategy } \\
\text { development }\end{array}$ & 0 & 1 & $\begin{array}{l}\text { FGM/C } \\
\text { strategy } \\
\text { Meeting } \\
\text { Minutes }\end{array}$ & Once & $\begin{array}{l}\text { Project } \\
\text { Manager }\end{array}$ \\
\hline
\end{tabular}

Output 1.1: Religious leaders sensitisation

\begin{tabular}{|c|c|c|c|c|c|c|c|}
\hline $\begin{array}{l}\text { Indicator } \\
01.1 \mathrm{a}\end{array}$ & $\begin{array}{l}\text { Anti FGM/C } \\
\text { statement by } \\
\text { religious leaders } \\
\text { produced }\end{array}$ & $\begin{array}{l}\text { This indicator } \\
\text { tracks the standard } \\
\text { statement expected } \\
\text { by religious } \\
\text { leaders to facilitate } \\
\text { implementation } \\
\text { of the project. The } \\
\text { statement will be } \\
\text { one, thus reported } \\
\text { once, however if } \\
\text { it's reviewed then it } \\
\text { should be reported } \\
\text { on in subsequent } \\
\text { years }\end{array}$ & 0 & 1 & $\begin{array}{l}\text { Religious } \\
\text { leaders } \\
\text { sensitisation } \\
\text { meeting } \\
\text { report }\end{array}$ & Once & $\begin{array}{l}\text { Project } \\
\text { Manager }\end{array}$ \\
\hline $\begin{array}{l}\text { Indicator } \\
01.1 \mathrm{~b}\end{array}$ & $\begin{array}{l}\text { Number of } \\
\text { religious leaders } \\
\text { supporting the } \\
\text { anti-FGM/C } \\
\text { statement }\end{array}$ & $\begin{array}{l}\text { This indicator will } \\
\text { track the number } \\
\text { of religious leaders } \\
\text { who support the } \\
\text { statement once it's } \\
\text { produced out of } \\
\text { those sensitised }\end{array}$ & & & $\begin{array}{l}\text { Attendance } \\
\text { list }\end{array}$ & & \\
\hline $\begin{array}{l}\text { Indicator } \\
\text { 01.1c }\end{array}$ & $\begin{array}{l}\text { Number of } \\
\text { religious leaders } \\
\text { sensitised on } \\
\text { FGM/C }\end{array}$ & $\begin{array}{l}\text { This refers to the } \\
\text { number of religious } \\
\text { leaders who are } \\
\text { sensitised on FGM/C }\end{array}$ & 0 & & $\begin{array}{l}\text { Attendance } \\
\text { list }\end{array}$ & Monthly & $\begin{array}{l}\text { Youth } \\
\text { Coordinator }\end{array}$ \\
\hline \multicolumn{8}{|c|}{ Output 1.2: Taskforce consultative meeting } \\
\hline $\begin{array}{l}\text { Indicator } \\
01.2 \mathrm{a}\end{array}$ & $\begin{array}{l}\text { Number of } \\
\text { ministries } \\
\text { represented } \\
\text { in the project } \\
\text { FGM/C taskforce }\end{array}$ & $\begin{array}{l}\text { This refers to } \\
\text { the government } \\
\text { ministries that will } \\
\text { be continuously } \\
\text { represented in the } \\
\text { project taskforce }\end{array}$ & $N / A$ & & $\begin{array}{l}\text { Attendance } \\
\text { list }\end{array}$ & Monthly & $\begin{array}{l}\text { Project } \\
\text { Manager }\end{array}$ \\
\hline
\end{tabular}




\begin{tabular}{|c|c|c|c|c|c|c|}
\hline $\begin{array}{l}\text { Indicator } \\
01.2 \mathrm{~b}\end{array}$ & $\begin{array}{l}\text { Number of } \\
\text { taskforce } \\
\text { meetings held }\end{array}$ & $\begin{array}{l}\text { Refers to the } \\
\text { number of taskforce } \\
\text { meetings held to } \\
\text { discuss project } \\
\text { implementation } \\
\text { progress }\end{array}$ & N/A & $\begin{array}{l}\text { Minutes of } \\
\text { the taskforce } \\
\text { meetings }\end{array}$ & Monthly & \\
\hline \multicolumn{7}{|c|}{ OBJECTIVE 2: To increase the public commitment to the eradication of FGM/C } \\
\hline $\begin{array}{l}\text { Indicator } \\
\text { OB2a }\end{array}$ & $\begin{array}{l}\text { Percentage } \\
\text { of population } \\
\text { supporting } \\
\text { abandonment } \\
\text { of FGM/C } \\
\text { (disaggregated } \\
\text { by gender, age, } \\
\text { beneficiary type) }\end{array}$ & $\begin{array}{l}\text { This refers to the } \\
\text { proportion of } \\
\text { population that } \\
\text { says they support } \\
\text { abandonment of } \\
\text { FGM/C } \\
\text { Numerator: Number } \\
\text { of people who } \\
\text { say they support } \\
\text { abandonment of } \\
\text { FGM/C amongst } \\
\text { those surveyed } \\
\text { Denominator: Total } \\
\text { number of people } \\
\text { surveyed } \\
\text { The indicator will } \\
\text { be disaggregated by } \\
\text { gender (male and } \\
\text { female), age and the } \\
\text { type of beneficiaries } \\
\text { as per the } \\
\text { project (teachers, } \\
\text { government } \\
\text { workers, nurses, } \\
\text { students etc.) }\end{array}$ & TBD & $\begin{array}{l}\text { Survey } \\
\text { questionnaire }\end{array}$ & Annually & $\begin{array}{l}\text { Research } \\
\text { Consultant }\end{array}$ \\
\hline $\begin{array}{l}\text { Indicator } \\
\text { OB2b }\end{array}$ & $\begin{array}{l}\text { Percentage of } \\
\text { people who } \\
\text { know the effects } \\
\text { of FGM/C } \\
\text { (disaggregated } \\
\text { by gender, age, } \\
\text { beneficiary type) }\end{array}$ & $\begin{array}{l}\text { This refers to the } \\
\text { proportion of people } \\
\text { who say they know a } \\
\text { minimum of certain } \\
\text { effects of FGM/C } \\
\text { as provided in the } \\
\text { survey instrument } \\
\text { Numerator: Number } \\
\text { of people who } \\
\text { state to know the } \\
\text { effects of FGM/C } \\
\text { as provided in the } \\
\text { study } \\
\text { Denominator: Total } \\
\text { number of people } \\
\text { surveyed } \\
\text { The indicator will } \\
\text { be disaggregated by } \\
\text { gender (male and } \\
\text { female), age group } \\
\text { of the population } \\
\text { and the type of } \\
\text { beneficiaries as } \\
\text { per the project } \\
\text { (teachers, } \\
\text { government } \\
\text { workers, nurses, } \\
\text { students etc.) }\end{array}$ & TBD & $\begin{array}{l}\text { Survey } \\
\text { questionnaire }\end{array}$ & Annually & $\begin{array}{l}\text { Research } \\
\text { Consultant }\end{array}$ \\
\hline
\end{tabular}




\begin{tabular}{|c|c|c|c|c|c|c|}
\hline $\begin{array}{l}\text { Indicator } \\
\text { OB2C }\end{array}$ & $\begin{array}{l}\text { Percentage } \\
\text { of people } \\
\text { who report } \\
\text { to have heard } \\
\text { anti-FGM/C } \\
\text { messages } \\
\text { (disaggregated } \\
\text { by gender, } \\
\text { age, source of } \\
\text { message) }\end{array}$ & $\begin{array}{l}\text { This refers to the } \\
\text { proportion of people } \\
\text { who report to have } \\
\text { heard anti-FGM/C } \\
\text { messages } \\
\text { Numerator: Number } \\
\text { of people who } \\
\text { report to have } \\
\text { heard anti-FGM/C } \\
\text { messages in the } \\
\text { study } \\
\text { Denominator: Total } \\
\text { number of people } \\
\text { surveyed } \\
\text { The indicator will } \\
\text { be disaggregated by } \\
\text { gender (male and } \\
\text { female), age and the } \\
\text { type of beneficiaries } \\
\text { as per the } \\
\text { project (teachers, } \\
\text { government } \\
\text { workers, nurses, } \\
\text { students etc.) }\end{array}$ & TBD & $\begin{array}{l}\text { Survey } \\
\text { questionnaire }\end{array}$ & Annually & $\begin{array}{l}\text { Research } \\
\text { Consultant }\end{array}$ \\
\hline $\begin{array}{l}\text { Indicator } \\
\text { OB2d }\end{array}$ & $\begin{array}{l}\text { Percentage } \\
\text { of population } \\
\text { supporting } \\
\text { alternative } \\
\text { FGM/C } \\
\text { (disaggregated } \\
\text { by gender, age, } \\
\text { beneficiary type } \\
\text { and type of } \\
\text { FGM/C practice) }\end{array}$ & $\begin{array}{l}\text { This refers to the } \\
\text { proportion of people } \\
\text { who state to support } \\
\text { other alternative } \\
\text { FGM/C practices } \\
\text { Numerator: Number } \\
\text { of people who state } \\
\text { to support other } \\
\text { alternative FGM/C } \\
\text { practices in the } \\
\text { study } \\
\text { Denominator: Total } \\
\text { number of people } \\
\text { surveyed } \\
\text { The indicator will } \\
\text { be disaggregated } \\
\text { by gender (male } \\
\text { and female), age, } \\
\text { type of beneficiaries } \\
\text { as per the } \\
\text { project (teachers, } \\
\text { government } \\
\text { workers, nurses, } \\
\text { students etc.) and } \\
\text { the type of practice } \\
\text { they support }\end{array}$ & TBD & $\begin{array}{l}\text { Survey } \\
\text { questionnaire }\end{array}$ & Annually & $\begin{array}{l}\text { Research } \\
\text { Consultant }\end{array}$ \\
\hline \multicolumn{7}{|c|}{ Output 2.1: Information, education and communication } \\
\hline $\begin{array}{l}\text { Indicator } \\
02.1 \mathrm{a}\end{array}$ & $\begin{array}{l}\text { Number of } \\
\text { anti-FGM/C } \\
\text { messages } \\
\text { produced } \\
\text { (specify type of } \\
\text { message) }\end{array}$ & $\begin{array}{l}\text { This indicator tracks } \\
\text { the anti-FGM/C } \\
\text { messages produced } \\
\text { during the life of the } \\
\text { project and the type } \\
\text { of message }\end{array}$ & 0 & IEC Records & Monthly & $\begin{array}{l}\text { Project } \\
\text { Manager }\end{array}$ \\
\hline
\end{tabular}




\begin{tabular}{|c|c|c|c|c|c|c|}
\hline $\begin{array}{l}\text { Indicator } \\
02.1 \mathrm{~b}\end{array}$ & $\begin{array}{l}\text { Number of anti- } \\
\text { FGM/C materials } \\
\text { disseminated } \\
\text { (disaggregated } \\
\text { by type of } \\
\text { material) }\end{array}$ & $\begin{array}{l}\text { This refers to } \\
\text { the anti-FGM/C } \\
\text { materials } \\
\text { disseminated to } \\
\text { the population } \\
\text { during the project } \\
\text { period. This will be } \\
\text { disaggregated by } \\
\text { the type of material } \\
\text { (e.g. brochures, } \\
\text { pamphlets, T-shirts } \\
\text { etc.) }\end{array}$ & 0 & $\begin{array}{l}\text { Distribution } \\
\text { lists }\end{array}$ & Monthly & $\begin{array}{l}\text { Project } \\
\text { Manager }\end{array}$ \\
\hline $\begin{array}{l}\text { Indicator } \\
02.1 \mathrm{c}\end{array}$ & $\begin{array}{l}\text { Number of } \\
\text { anti-FGM/C } \\
\text { messages } \\
\text { shared publicly } \\
\text { through media } \\
\text { (disaggregated } \\
\text { by type of } \\
\text { media) }\end{array}$ & $\begin{array}{l}\text { This indicator } \\
\text { will track the } \\
\text { number of anti- } \\
\text { FGM/C messages } \\
\text { disseminated } \\
\text { through public } \\
\text { media, and will be } \\
\text { disaggregated by the } \\
\text { type of media used } \\
\text { to disseminate (TV, } \\
\text { radio, print media, } \\
\text { social media) }\end{array}$ & 0 & Media records & Monthly & $\begin{array}{l}\text { Project } \\
\text { Manager }\end{array}$ \\
\hline $\begin{array}{l}\text { Indicator } \\
\text { 02.1d }\end{array}$ & $\begin{array}{l}\text { Number } \\
\text { of FGM/C } \\
\text { questions raised } \\
\text { during media } \\
\text { talk shows }\end{array}$ & $\begin{array}{l}\text { This will count the } \\
\text { interactive questions } \\
\text { raised by listeners } \\
\text { during the media } \\
\text { talks shows. The } \\
\text { host will keep a } \\
\text { record of how many } \\
\text { FGM/C related } \\
\text { questions were } \\
\text { raised to gauge the } \\
\text { public participation }\end{array}$ & 0 & Media records & Monthly & $\begin{array}{l}\text { Project } \\
\text { Manager }\end{array}$ \\
\hline
\end{tabular}

\section{Output 2.2: School interventions}

\begin{tabular}{|c|c|c|c|c|c|c|}
\hline $\begin{array}{l}\text { Indicator } \\
02.2 \mathrm{a}\end{array}$ & $\begin{array}{l}\text { Number of } \\
\text { parents with } \\
\text { primary school } \\
\text { girls reached } \\
\text { with FGM/C } \\
\text { messages } \\
\text { (disaggregated } \\
\text { by gender) }\end{array}$ & $\begin{array}{l}\text { This will count } \\
\text { number of parents } \\
\text { with primary school } \\
\text { girl children who are } \\
\text { reached with FGM/C } \\
\text { messages through } \\
\text { sensitisation } \\
\text { meetings. The } \\
\text { indicator will be } \\
\text { disaggregated by the } \\
\text { gender of the parent } \\
\text { (male and female) }\end{array}$ & 0 & $\begin{array}{l}\text { Attendance } \\
\text { list }\end{array}$ & Monthly & $\begin{array}{l}\text { Youth } \\
\text { Volunteers }\end{array}$ \\
\hline $\begin{array}{l}\text { Indicator } \\
\mathrm{O} 2.2 \mathrm{~b}\end{array}$ & $\begin{array}{l}\text { Number of } \\
\text { students } \\
\text { reached } \\
\text { with FGM/C } \\
\text { messages } \\
\text { (disaggregated } \\
\text { by gender and } \\
\text { secondary/ } \\
\text { higher } \\
\text { institutions) }\end{array}$ & $\begin{array}{l}\text { This will count } \\
\text { number of students } \\
\text { targeted with } \\
\text { FGM/C messages } \\
\text { through sensitisation } \\
\text { meetings in } \\
\text { secondary schools } \\
\text { and universities. } \\
\text { The indicator will } \\
\text { be disaggregate by } \\
\text { the gender of the } \\
\text { students, and type } \\
\text { of institution }\end{array}$ & 0 & $\begin{array}{l}\text { Attendance } \\
\text { list }\end{array}$ & Monthly & $\begin{array}{l}\text { Youth } \\
\text { Volunteers }\end{array}$ \\
\hline
\end{tabular}




\begin{tabular}{|c|c|c|c|c|c|c|}
\hline $\begin{array}{l}\text { Indicator } \\
02.3 a\end{array}$ & $\begin{array}{l}\text { Number } \\
\text { of young } \\
\text { volunteers } \\
\text { trained as } \\
\text { trainers of } \\
\text { trainers (TOTs) } \\
\text { (disaggregated } \\
\text { by gender) }\end{array}$ & $\begin{array}{l}\text { This refers to the } \\
\text { number of project } \\
\text { youth volunteers } \\
\text { who are trained } \\
\text { as trainers by } \\
\text { the project. This } \\
\text { indicator should be } \\
\text { disaggregated by } \\
\text { gender (male and } \\
\text { female) }\end{array}$ & 0 & $\begin{array}{l}\text { Attendance } \\
\text { list }\end{array}$ & Monthly & $\begin{array}{l}\text { Youth } \\
\text { coordinator }\end{array}$ \\
\hline $\begin{array}{l}\text { Indicator } \\
02.3 b\end{array}$ & $\begin{array}{l}\text { Number of } \\
\text { youth volunteers } \\
\text { trained } \\
\text { (disaggregated } \\
\text { by gender and } \\
\text { type of training; } \\
\text { comprehensive } \\
\text { sexual education } \\
\text { (CSE), FGM/C, } \\
\text { advocacy } \\
\text { participation) }\end{array}$ & $\begin{array}{l}\text { This refers to the } \\
\text { number of youth } \\
\text { volunteer who are } \\
\text { trained by the TOTs } \\
\text { on various aspects. } \\
\text { This indicator should } \\
\text { be disaggregated } \\
\text { by gender of the } \\
\text { trainees, and the } \\
\text { type of training } \\
\text { attended }\end{array}$ & 0 & $\begin{array}{l}\text { Attendance } \\
\text { list }\end{array}$ & Monthly & $\begin{array}{l}\text { Youth } \\
\text { coordinator }\end{array}$ \\
\hline $\begin{array}{l}\text { Indicator } \\
02.3 \mathrm{C}\end{array}$ & $\begin{array}{l}\text { Number of } \\
\text { nurses and } \\
\text { midwives } \\
\text { trained on } \\
\text { medical } \\
\text { complications of } \\
\text { FGM/C }\end{array}$ & $\begin{array}{l}\text { This refers to the } \\
\text { number of nurses } \\
\text { and midwives } \\
\text { who are trained } \\
\text { on medical } \\
\text { complications } \\
\text { of FGM/C and } \\
\text { related treatment } \\
\text { disaggregated } \\
\text { by gender of } \\
\text { participants }\end{array}$ & 0 & $\begin{array}{l}\text { Attendance } \\
\text { list }\end{array}$ & Monthly & $\begin{array}{l}\text { Youth } \\
\text { Volunteers }\end{array}$ \\
\hline $\begin{array}{l}\text { Indicator } \\
\text { O2.3d }\end{array}$ & $\begin{array}{l}\text { Number } \\
\text { of student } \\
\text { nurses trained } \\
\text { on medical } \\
\text { complications of } \\
\text { FGM/C }\end{array}$ & $\begin{array}{l}\text { This refers to the } \\
\text { number of nurses } \\
\text { and midwives } \\
\text { who are trained } \\
\text { on medical } \\
\text { complications } \\
\text { of FGM/C and } \\
\text { related treatment } \\
\text { disaggregated } \\
\text { by gender of } \\
\text { participants }\end{array}$ & 0 & $\begin{array}{l}\text { Attendance } \\
\text { list }\end{array}$ & Monthly & $\begin{array}{l}\text { Youth } \\
\text { Volunteers }\end{array}$ \\
\hline $\begin{array}{l}\text { Indicator } \\
\text { O2.3e }\end{array}$ & $\begin{array}{l}\text { Number of } \\
\text { staff and youth } \\
\text { volunteers } \\
\text { trained on social } \\
\text { media use }\end{array}$ & $\begin{array}{l}\text { This refers to the } \\
\text { number of staff and } \\
\text { youth volunteers } \\
\text { who have been } \\
\text { trained on using } \\
\text { social media to } \\
\text { influence FGM/C } \\
\text { practices and create } \\
\text { awareness. This } \\
\text { indicator should } \\
\text { be disaggregated } \\
\text { by gender of the } \\
\text { trainees }\end{array}$ & 0 & $\begin{array}{l}\text { Attendance } \\
\text { list }\end{array}$ & Monthly & $\begin{array}{l}\text { Youth } \\
\text { Volunteers }\end{array}$ \\
\hline
\end{tabular}




\begin{tabular}{|c|c|c|c|c|c|c|}
\hline $\begin{array}{l}\text { Indicator } \\
02.3 f\end{array}$ & $\begin{array}{l}\text { Number of } \\
\text { media persons } \\
\text { trained } \\
\text { on sexual } \\
\text { reproductive } \\
\text { and health } \\
\text { rights (SRHR) } \\
\text { and FGM/C } \\
\text { (disaggregated } \\
\text { by gender and } \\
\text { type of media) }\end{array}$ & $\begin{array}{l}\text { This refers to the } \\
\text { number of media } \\
\text { persons who have } \\
\text { been trained on } \\
\text { SRHR and FGM/C } \\
\text { practices to create } \\
\text { awareness. This } \\
\text { indicator should } \\
\text { be disaggregated } \\
\text { by gender of the } \\
\text { trainees and the } \\
\text { type of media they } \\
\text { represent (e.g. radio, } \\
\text { print, TV etc.) }\end{array}$ & 0 & $\begin{array}{l}\text { Attendance } \\
\text { list }\end{array}$ & Monthly & $\begin{array}{l}\text { Youth } \\
\text { Volunteers }\end{array}$ \\
\hline $\begin{array}{l}\text { Indicator } \\
02.3 \mathrm{~g}\end{array}$ & $\begin{array}{l}\text { Number of anti- } \\
\text { FGM/C dialogue } \\
\text { forums/ } \\
\text { sessions held } \\
\text { (disaggregated } \\
\text { by religious } \\
\text { leaders, youth, } \\
\text { teachers, nurses } \\
\text { and community) }\end{array}$ & $\begin{array}{l}\text { This counts the } \\
\text { number of dialogue } \\
\text { sessions held by } \\
\text { various groups of } \\
\text { people supported } \\
\text { by the project. This } \\
\text { indicator should be } \\
\text { disaggregated by } \\
\text { type of beneficiaries } \\
\text { reached through } \\
\text { dialogue sessions }\end{array}$ & 0 & $\begin{array}{l}\text { Dialogue } \\
\text { forum records }\end{array}$ & Monthly & $\begin{array}{l}\text { Youth } \\
\text { Volunteers }\end{array}$ \\
\hline \multicolumn{7}{|c|}{ Output 2.4: Sensitisation of government workers } \\
\hline $\begin{array}{l}\text { Indicator } \\
02.4 \mathrm{a}\end{array}$ & $\begin{array}{l}\text { Number of } \\
\text { government } \\
\text { workers } \\
\text { sensitised } \\
\text { on FGM/C } \\
\text { (disaggregated } \\
\text { by gender) }\end{array}$ & $\begin{array}{l}\text { This refers to } \\
\text { the number of } \\
\text { government } \\
\text { workers who have } \\
\text { been sensitised } \\
\text { on FGM/C during } \\
\text { the project period } \\
\text { disaggregated } \\
\text { by gender of the } \\
\text { participant }\end{array}$ & 0 & $\begin{array}{l}\text { Attendance } \\
\text { list }\end{array}$ & Monthly & $\begin{array}{l}\text { Youth } \\
\text { Volunteers }\end{array}$ \\
\hline $\begin{array}{l}\text { Indicator } \\
02.4 \mathrm{~b}\end{array}$ & $\begin{array}{l}\text { Number of } \\
\text { TBAs and older } \\
\text { women reached } \\
\text { with FGM/C } \\
\text { awareness } \\
\text { sessions }\end{array}$ & $\begin{array}{l}\text { This refers to the } \\
\text { number of TBAs and } \\
\text { older women who } \\
\text { have been reached } \\
\text { through FGM/C } \\
\text { awareness sessions } \\
\text { during the project } \\
\text { period }\end{array}$ & 0 & $\begin{array}{l}\text { Attendance } \\
\text { list }\end{array}$ & Monthly & $\begin{array}{l}\text { Youth } \\
\text { Volunteers }\end{array}$ \\
\hline \multicolumn{7}{|c|}{ Output 2.5: Volunteer appreciation day } \\
\hline $\begin{array}{l}\text { Indicator } \\
02.5 a\end{array}$ & $\begin{array}{l}\text { Number of } \\
\text { youths who } \\
\text { share FGM/C } \\
\text { related } \\
\text { success stories } \\
\text { (disaggregated } \\
\text { by gender) }\end{array}$ & $\begin{array}{l}\text { This will count } \\
\text { the number of } \\
\text { youth who attend } \\
\text { the volunteer } \\
\text { appreciation day and } \\
\text { share FGM/C related } \\
\text { success stories }\end{array}$ & 0 & $\begin{array}{l}\text { Success } \\
\text { stories }\end{array}$ & Annually & $\begin{array}{l}\text { Youth } \\
\text { Volunteers }\end{array}$ \\
\hline $\begin{array}{l}\text { Indicator } \\
02.5 \mathrm{~b}\end{array}$ & $\begin{array}{l}\text { Number } \\
\text { of youths } \\
\text { attending the } \\
\text { appreciation day } \\
\text { (disaggregated } \\
\text { by gender) }\end{array}$ & $\begin{array}{l}\text { This will count the } \\
\text { number of youths } \\
\text { who attend the } \\
\text { appreciation day } \\
\text { disaggregated by } \\
\text { gender }\end{array}$ & 0 & $\begin{array}{l}\text { Attendance } \\
\text { list }\end{array}$ & Annually & $\begin{array}{l}\text { Youth } \\
\text { Volunteers }\end{array}$ \\
\hline
\end{tabular}


OBJECTIVE 3: To promote the criminalisation of medicalisation of FGM/C in Somaliland

\begin{tabular}{|c|c|c|c|c|c|c|}
\hline $\begin{array}{l}\text { Indicator } \\
\text { OB } 3.1\end{array}$ & $\begin{array}{l}\text { Criminalisation } \\
\text { of medicalisation } \\
\text { of FGM/C policy } \\
\text { approved }\end{array}$ & $\begin{array}{l}\text { This indicator } \\
\text { tracks the progress } \\
\text { on lobbying and } \\
\text { advocating for } \\
\text { approval of FGM/C } \\
\text { policy }\end{array}$ & 0 & & & \\
\hline \multicolumn{7}{|c|}{ Output 3.1: Advocacy for approval of criminalisation policy } \\
\hline $\begin{array}{l}\text { Indicator } \\
\text { O3.1a }\end{array}$ & $\begin{array}{l}\text { Number of } \\
\text { stakeholders } \\
\text { involved in } \\
\text { advocating for } \\
\text { approval of } \\
\text { criminalisation } \\
\text { laws } \\
\text { (disaggregated } \\
\text { by stakeholder } \\
\text { type) }\end{array}$ & $\begin{array}{l}\text { This indicator } \\
\text { will count the } \\
\text { different types of } \\
\text { stakeholders who } \\
\text { are involved in the } \\
\text { meeting with key } \\
\text { government entities } \\
\text { to advocate for } \\
\text { approval of FGM/C } \\
\text { policy }\end{array}$ & 0 & $\begin{array}{l}\text { Attendance } \\
\text { list/Minutes } \\
\text { of the } \\
\text { meetings }\end{array}$ & Monthly & $\begin{array}{l}\text { Project } \\
\text { Manager }\end{array}$ \\
\hline $\begin{array}{l}\text { Indicator } \\
\text { O3.1b }\end{array}$ & $\begin{array}{l}\text { Number of } \\
\text { taskforce } \\
\text { meetings } \\
\text { discussing } \\
\text { adoption of } \\
\text { criminalisation } \\
\text { of medicalisation } \\
\text { policy }\end{array}$ & $\begin{array}{l}\text { This indicator will } \\
\text { count the number of } \\
\text { taskforce meetings } \\
\text { that deliberately } \\
\text { discuss the adoption } \\
\text { of criminalisation of } \\
\text { medicalisation policy }\end{array}$ & 0 & $\begin{array}{l}\text { Attendance } \\
\text { list/Minutes } \\
\text { of the } \\
\text { meetings }\end{array}$ & Monthly & $\begin{array}{l}\text { Project } \\
\text { Manager }\end{array}$ \\
\hline $\begin{array}{l}\text { Indicator } \\
\text { O3.1c }\end{array}$ & $\begin{array}{l}\text { Number of } \\
\text { meetings } \\
\text { held with key } \\
\text { government } \\
\text { entities to } \\
\text { push for } \\
\text { approval of the } \\
\text { criminalisation } \\
\text { policy }\end{array}$ & $\begin{array}{l}\text { This indicator will } \\
\text { count the number } \\
\text { of meetings with } \\
\text { key government } \\
\text { entities that } \\
\text { deliberately discuss } \\
\text { and advocate for } \\
\text { adoption of the } \\
\text { criminalisation of } \\
\text { medicalisation policy }\end{array}$ & 0 & $\begin{array}{l}\text { Minutes of } \\
\text { the meetings }\end{array}$ & Monthly & $\begin{array}{l}\text { Project } \\
\text { Manager }\end{array}$ \\
\hline
\end{tabular}

\section{OBJECTIVE 4: To reduce the health and social complications resulting from FGM/C procedures}

\begin{tabular}{|c|c|c|c|c|c|c|}
\hline $\begin{array}{l}\text { Indicator } \\
\text { OB4a }\end{array}$ & $\begin{array}{l}\text { Percentage of } \\
\text { women and } \\
\text { girls affected } \\
\text { by FGM/C who } \\
\text { have received } \\
\text { FGM/C related } \\
\text { clinical and } \\
\text { support services } \\
\text { (disaggregated } \\
\text { by age and type } \\
\text { of service) }\end{array}$ & $\begin{array}{l}\text { This refers to the } \\
\text { proportion of } \\
\text { women and girls } \\
\text { affected by FGM/C } \\
\text { who report to have } \\
\text { been reached with } \\
\text { FGM/C support } \\
\text { services and clinical } \\
\text { services } \\
\text { Numerator: Number } \\
\text { of women and girls } \\
\text { affected by FGM/C } \\
\text { reporting to have } \\
\text { received support } \\
\text { services } \\
\text { Denominator: } \\
\text { Number of women } \\
\text { and girls surveyed } \\
\text { This indicator will } \\
\text { be disaggregated } \\
\text { by age of the } \\
\text { beneficiary and type } \\
\text { of service provided } \\
\text { (clinical/support) }\end{array}$ & TBD & $\begin{array}{l}\text { Survey } \\
\text { questionnaire }\end{array}$ & Annually & $\begin{array}{l}\text { Research } \\
\text { Consultant }\end{array}$ \\
\hline
\end{tabular}




\begin{tabular}{|c|c|c|c|c|c|c|}
\hline $\begin{array}{l}\text { Indicator } \\
\text { OB4b }\end{array}$ & $\begin{array}{l}\text { Proportion of } \\
\text { health workers } \\
\text { with skills in } \\
\text { treating FGM/C } \\
\text { complications }\end{array}$ & $\begin{array}{l}\text { This refers to the } \\
\text { ratio of health } \\
\text { workers who have } \\
\text { skills to treat FGM/C } \\
\text { complications. } \\
\text { The skills will be } \\
\text { established using } \\
\text { criteria as proposed } \\
\text { in the survey } \\
\text { Numerator: } \\
\text { Number of health } \\
\text { workers who have } \\
\text { the required skills } \\
\text { to treat FGM/C } \\
\text { complications in the } \\
\text { sites surveyed } \\
\text { Denominator: Total } \\
\text { number of health } \\
\text { workers in the } \\
\text { surveyed sites }\end{array}$ & TBD & $\begin{array}{l}\text { Survey } \\
\text { questionnaire }\end{array}$ & Annually & $\begin{array}{l}\text { Research } \\
\text { Consultant }\end{array}$ \\
\hline \multicolumn{7}{|c|}{ Output 4.1: Provision of clinical services, referral services and social support } \\
\hline $\begin{array}{l}\text { Indicator } \\
\text { 04.1a }\end{array}$ & $\begin{array}{l}\text { Number of girls } \\
\text { and women } \\
\text { affected by } \\
\text { FGM/C receiving } \\
\text { clinical services } \\
\text { (disaggregate by } \\
\text { age and type of } \\
\text { service) }\end{array}$ & $\begin{array}{l}\text { This refers to } \\
\text { number of girls } \\
\text { and women who } \\
\text { are affected by } \\
\text { FGM/C and have } \\
\text { received clinical } \\
\text { services at project } \\
\text { intervention sites. } \\
\text { This indicator should } \\
\text { be disaggregated } \\
\text { by age of client } \\
\text { and type of service } \\
\text { offered }\end{array}$ & 0 & $\begin{array}{l}\text { Clinical } \\
\text { service } \\
\text { registers }\end{array}$ & Monthly & $\begin{array}{l}\text { Clinical staff/ } \\
\text { Health care } \\
\text { workers }\end{array}$ \\
\hline $\begin{array}{l}\text { Indicator } \\
\text { 04.1b }\end{array}$ & $\begin{array}{l}\text { Number of } \\
\text { women and } \\
\text { girls referred } \\
\text { for FGM/C } \\
\text { clinical services } \\
\text { (referred to } \\
\text { and from, } \\
\text { disaggregated by } \\
\text { type of service) }\end{array}$ & $\begin{array}{l}\text { This refers to } \\
\text { women and girls } \\
\text { who have been } \\
\text { referred from } \\
\text { intervention sites } \\
\text { and those who } \\
\text { have been referred } \\
\text { from other areas } \\
\text { to the project } \\
\text { intervention sites. } \\
\text { This indicator should } \\
\text { be disaggregated by } \\
\text { referral from and } \\
\text { to, and the type of } \\
\text { service the person } \\
\text { has been referred } \\
\text { for }\end{array}$ & 0 & $\begin{array}{l}\text { Clinical } \\
\text { service } \\
\text { registers/ } \\
\text { Referral cards }\end{array}$ & Monthly & $\begin{array}{l}\text { Clinical staff/ } \\
\text { Health care } \\
\text { workers }\end{array}$ \\
\hline
\end{tabular}




\begin{tabular}{|c|c|c|c|c|c|c|c|}
\hline $\begin{array}{l}\text { Indicator } \\
\text { 04.1c }\end{array}$ & $\begin{array}{l}\text { Number of } \\
\text { vulnerable girls } \\
\text { and women } \\
\text { affected by } \\
\text { FGM/C receiving } \\
\text { social support } \\
\text { (disaggregated } \\
\text { by age and type } \\
\text { of service) }\end{array}$ & $\begin{array}{l}\text { This refers to } \\
\text { number of girls and } \\
\text { women who are } \\
\text { affected by FGM/C } \\
\text { and have been } \\
\text { offered project } \\
\text { support services. } \\
\text { This indicator should } \\
\text { be disaggregated } \\
\text { by age of client } \\
\text { and type of service } \\
\text { offered }\end{array}$ & & & $\begin{array}{l}\text { Support } \\
\text { services } \\
\text { records }\end{array}$ & Monthly & $\begin{array}{l}\text { Youth } \\
\text { volunteers }\end{array}$ \\
\hline \multicolumn{8}{|c|}{ Output 4.2: Women and girls' sports empowerment centre } \\
\hline $\begin{array}{l}\text { Indicator } \\
04.2 a\end{array}$ & $\begin{array}{l}\text { Women } \\
\text { and girls' } \\
\text { empowerment } \\
\text { centre } \\
\text { established }\end{array}$ & $\begin{array}{l}\text { This indicator tracks } \\
\text { the establishment } \\
\text { of the women and } \\
\text { girls' sports centre. } \\
\text { The indicator will be } \\
\text { reported on once } \\
\text { the centre has been } \\
\text { established and is in } \\
\text { use by the women } \\
\text { and girls }\end{array}$ & 0 & 1 & $\begin{array}{l}\text { Youth center } \\
\text { record/ } \\
\text { pictures }\end{array}$ & Once & $\begin{array}{l}\text { Project } \\
\text { Manager }\end{array}$ \\
\hline $\begin{array}{l}\text { Indicator } \\
04.2 \mathrm{~b}\end{array}$ & $\begin{array}{l}\text { Number of } \\
\text { women and } \\
\text { girls accessing } \\
\text { the sports } \\
\text { empowerment } \\
\text { centre } \\
\text { (disaggregated } \\
\text { by type } \\
\text { of service } \\
\text { accessed) }\end{array}$ & $\begin{array}{l}\text { This refers to } \\
\text { women and girls } \\
\text { utilising the sports } \\
\text { empowerment } \\
\text { centres services } \\
\text { once it's established. } \\
\text { It envisioned } \\
\text { this would be } \\
\text { established at the } \\
\text { end of the project } \\
\text { however should } \\
\text { it be established } \\
\text { earlier, this indicator } \\
\text { should be reported } \\
\text { on. }\end{array}$ & 0 & & $\begin{array}{l}\text { Youth center } \\
\text { attendance } \\
\text { registers }\end{array}$ & Monthly & $\begin{array}{l}\text { Youth } \\
\text { volunteers }\end{array}$ \\
\hline
\end{tabular}

Text highlighted in orange identifies which project indicators the research focused on. 


\section{Appendix C: Community survey questions}

\section{SOFHA baseline questionnaire}

Date of interview

Name of community researcher

Consent questions

Has the purpose of the interview been explained to you?

Are you willing to continue with the questions?

Background information

Which region do you live in?

Community name

Is this a CITY, SEMI-CITY or VILLAGE community?

Male or female

Age

Are you attending school or university now?

If yes, what type of school?

If yes, what class are you in?

Have you attended school in the past?

If yes, what type of school?

If yes, how far did you progress?

Are you married?

Are you a parent?

If yes, do you have GIRLS at primary school now?

What type of school do your daughters attend?

If other, please explain

If yes, are any in grades 1-3?

What do you do?

If other, please explain

If government worker, what is your job?

If a health worker, where do you work?

If other please state where?

This survey is about female genital cutting

1. Have you heard about girls being cut?

2. Do you know that girls can be cut in different ways?

3. Can you explain the different types?

If other, please explain
4. Does the cutting of girls take place in your community?

Is it by all, by most, by just a few?

5a. What problems does cutting WITH stitches cause among girls and women?

If other, please explain

5b. What problems does cutting WITHOUT stitches cause among girls and women?

If other, please explain

Questions for women only

Are you willing to answer some more personal questions about female genital cutting?

6. Have you been cut?

If not, do you expect to be cut in the future?

7. What age were you when you were cut?

8. What type of cut did you have?

If other, please explain

9. Who carried out your cutting?

If other, please explain

10. Did you have any complications soon after you were cut?

11. What kind of complications did you have?

If other, please explain

12. Did you ask anyone for help?

If yes, who did you ask?

If other, please explain

13. Have you had any long term complications as a result of being cut?

If other, please explain

14. Were you cut on your wedding night?

15. Do you have any daughters?

Consent question - Are you willing to answer some questions about your daughters?

16. How many?

17. Have any been cut? (including the sunna)

How many?

18. At what age were they cut?

19. Who carried out the cutting of your daughters?

If other, please explain

20. Which type of cut was carried out on your daughters?

If other, please explain 
21. Have any of your daughters had complications when they were cut?

22. If yes, what kind of complications did they have?

If other, please explain

23. Do you have any uncut daughters?

24. Will they be cut when they are older?

25a. If yes, at what age will they be cut?

25b. If no, why will they not be cut?

If other, please explain

26. Which type of cut will be carried out on your uncut daughters?

Questions to ALL interviewees

27. Do you intend to cut any daughters you have in the future?

28a. If yes, which type of cut?

If other, please explain

28b. If no, why will they not be cut?

Questions to young women only

29. As a young woman would you intervene to protect young girls from being cut?

If other, please explain

30a. If yes, how?

If other, please explain

30b. If not, why not?

If other, please explain

Questions to married men only

32. Do you discuss the cutting of your daughters with your wife?

If not, why not?

Questions for ALL interviewees

33. Would you prefer a son of yours to marry a girl who is cut or uncut?

If cut, which type?

Questions for unmarried men

34. As an unmarried man which kind of girl would you prefer to marry?

If other, please explain

35a. How much does it matter whether the girl you marry has been cut?

If other, please explain

35b. How would you find out if a young woman you intend to marry was cut?
Questions for ALL teachers

36. What do you see as the role of SCHOOLS and COLLEGES in relation to female genital cutting?

If other, please explain

37. Do you talk about female genital cutting in your school or college?

If yes, when

If other, please explain

38. Do girls ever come to you as a teacher for advice or support on female genital cutting?

39. If yes, what advice are you able to offer?

If other, please explain

40. Before the school holidays when girls are cut, do you take any action to protect girls?

41. If yes, which of these?

If other, please explain

Questions for ALL interviewees

42. Have you heard any messages about female genital cutting in your community?

43. If yes what kind of messages are being given?

If other, please explain

44. If yes, from whom?

If other, please explain

45. Are you involved in any activities against female genital cutting in your community?

46. If yes, what kind of activity?

If other, please state

47. Would you like to be involved in activities against female genital cutting in the future?

48. If yes, which kinds of activities?

If other, please explain

49. What has stopped you getting involved already?

If other, please explain

50. Which types of cutting do you think should be abandoned in your community? 


\section{Appendix D: Interviewees}

\begin{tabular}{|c|c|c|c|c|c|}
\hline Region & Community & $\begin{array}{l}\text { City/semi-city/ } \\
\text { village }\end{array}$ & $\begin{array}{l}\text { No. female } \\
\text { interviewees }\end{array}$ & $\begin{array}{l}\text { No. of male } \\
\text { interviewees }\end{array}$ & $\begin{array}{l}\text { Total } \\
\text { interviewees }\end{array}$ \\
\hline \multirow[t]{8}{*}{ Sanaag } & Daallo (Cerigabo) & City & 23 & 42 & 65 \\
\hline & Yufle & Village & 60 & 57 & 117 \\
\hline & Gudmo Biyo Cas & Village & 59 & 61 & 120 \\
\hline & October (Sanaag) (Cerigabo) & City & 8 & 19 & 27 \\
\hline & Xaafadsoomaal (Cerigabo) & City & 40 & 31 & 71 \\
\hline & Shacabka (Cerigabo) & City & 55 & 40 & 95 \\
\hline & Other Sanaag * & & 10 & 5 & 15 \\
\hline & Total & & 255 & 255 & 510 \\
\hline \multirow[t]{6}{*}{ Awdal } & Sheeddheer (Borama) & City & 32 & 29 & 61 \\
\hline & Sheekh Ali Jawhar (Borama) & City & 23 & 31 & 54 \\
\hline & Dilla & Semi City & 52 & 45 & 97 \\
\hline & Qulujeed & Village & 54 & 48 & 102 \\
\hline & Gorayo Cawl & Village & 33 & 35 & 68 \\
\hline & Total & & 194 & 188 & 382 \\
\hline \multirow[t]{6}{*}{ Saaxil } & Moskow (Berbera) & City & 54 & 45 & 99 \\
\hline & Barwaaqo (Berbera) & City & 62 & 42 & 104 \\
\hline & Sheekh & Semi City & 53 & 56 & 109 \\
\hline & Abdaal & Village & 48 & 38 & 86 \\
\hline & Xamaas & Village & 50 & 29 & 79 \\
\hline & Total & & 267 & 210 & 477 \\
\hline \multirow[t]{3}{*}{ Togdheer } & Yaroowe & Village & 49 & 47 & 96 \\
\hline & October (Burao) & City & 67 & 49 & 116 \\
\hline & Total & & 116 & 96 & 212 \\
\hline \multirow[t]{4}{*}{ Maroodi Jeex } & Baligubadle & Semi City & 55 & 47 & 102 \\
\hline & Ahmed Dhagax (Hargeisa) & City & 84 & 80 & 164 \\
\hline & Total & & 139 & 127 & 266 \\
\hline & Grand total & & 971 & 876 & 1847 \\
\hline
\end{tabular}




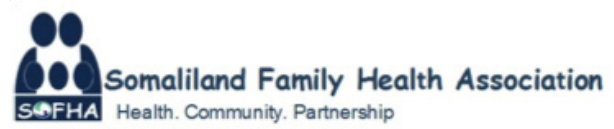

POPULATION COUNCIL

Ideas. Evidence. Impact.

\section{ORCHID PROJECT}

WORKING TOGETHER TO END

FEMALE GENITAL CUTTING

Norad 